San Jose State University

SJSU ScholarWorks

Master's Theses

Master's Theses and Graduate Research

Spring 2018

\title{
The Design and Detailing of Discontinuous Timberframe Lateral- Force-Resisting Systems
}

Rhett Kenneth Carlsen

San Jose State University

Follow this and additional works at: https://scholarworks.sjsu.edu/etd_theses

\section{Recommended Citation}

Carlsen, Rhett Kenneth, "The Design and Detailing of Discontinuous Timberframe Lateral-Force-Resisting Systems" (2018). Master's Theses. 4894. DOI: https://doi.org/10.31979/etd.tc68-85sz

https://scholarworks.sjsu.edu/etd_theses/4894

This Thesis is brought to you for free and open access by the Master's Theses and Graduate Research at SJSU ScholarWorks. It has been accepted for inclusion in Master's Theses by an authorized administrator of SJSU ScholarWorks. For more information, please contact scholarworks@sjsu.edu. 


\title{
THE DESIGN AND DETAILING OF DISCONTINUOUS TIMBERFRAME
} LATERAL-FORCE-RESISTING SYSTEMS

\author{
A Thesis \\ Presented to \\ The Faculty of the Department of Civil and Environmental Engineering \\ San José State University \\ In Partial Fulfillment \\ of the Requirements for the Degree \\ Master of Science
}

by

Rhett Kenneth Carlsen

May 2018 
(C) 2018

Rhett Carlsen

ALL RIGHTS RESERVED 
The Designated Thesis Committee Approves the Thesis Titled

\title{
THE DESIGN AND DETAILING OF DISCONTINUOUS TIMBERFRAME LATERAL-FORCE-RESISTING SYSTEMS
}

\author{
by \\ Rhett Carlsen \\ APPROVED FOR THE DEPARTMENT OF CIVIL \\ AND ENVIRONMENTAL ENGINEERING
}

SAN JOSÉ STATE UNIVERSITY

May 2018

Kurt M. McMullin, Ph.D. Department of Civil Engineering

Ajay Singhal, Ph.D. Department of Civil Engineering

Mohamed Soliman, Ph.D. Department of Civil Engineering 


\title{
ABSTRACT \\ THE DESIGN AND DETAILING OF DISCONTINUOUS TIMBERFRAME LATERAL-FORCE-RESISTING SYSTEMS
}

\author{
by Rhett Carlsen
}

Discontinuous lateral-force-resisting systems (LFRS) are a type of LFRS in which the path of resistance does not continue directly to the foundation. Discontinuous systems are defined as either in-plane, where the LRFS shifts in the plane of resistance, or out-ofplane, where the shift is perpendicular to the plane of resistance. Discontinuous systems are especially prevalent in lightweight, woodframe structures. Design penalties exist for discontinuous systems, resulting in the specification of larger connections and structural elements. This research includes a review of past experiments to identify any discontinuous LFRS experiments that have been conducted. Through the identification of the existence and design of these systems, critical variables are defined. A hypothetical prototype, single-family-residence style, structure has been designed and analyzed to exemplify the proper application of ASCE 7-10 ASD load combinations pertinent to inplane, vertically irregular discontinuous LFRS, as well as to aide in the design of a full scale test specimen built by a 3-semester unit, graduate level, structural engineering course at San José State University (SJSU). Connection detail examples are produced from the results of the prototype structure analysis. Suggestions for application to structural design and connection detailing are made, in addition to suggestions for further experimental research. 


\section{ACKNOWLEDGMENTS}

I would like to first acknowledge the Charles W. Davidson School of Engineering at San Jose State University for providing funding to make this project a possibility. Thanks are also extended to Kurt McMullin for his guidance and expertise throughout the process of this project. The efforts of thesis committee review members Ajay Singhal and Mohamed Soliman are greatly appreciated. Finally, I thank my parents for their endless support in all of my endeavors. 


\section{TABLE OF CONTENTS}

List of Tables viii

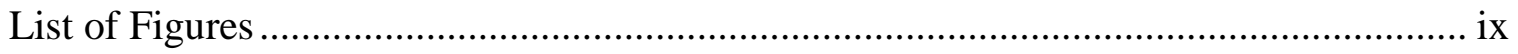

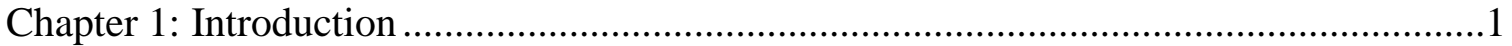

1.1 Discontinuous Lateral Force Resisting Systems ..............................................

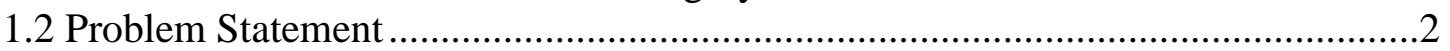

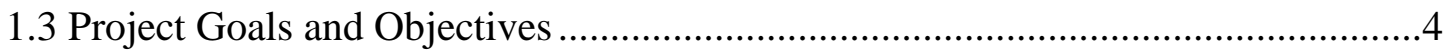

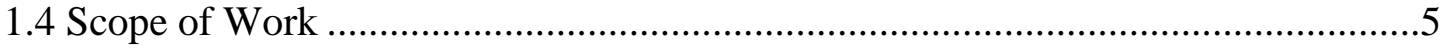

Chapter 2: Literature Review ..............................................................................6

2.1 Building Codes Related to Discontinuous Structural Systems Intended to

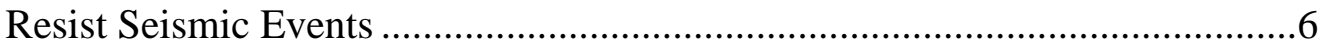

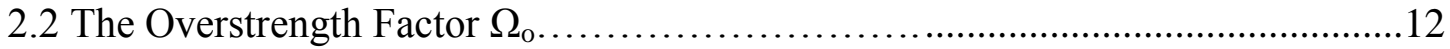

2.3 Woodframe Structures of the CUREe-Caltech Fischer Woodframe Project..........16

2.4 Woodframe Structures of the E-Defense Projects ...............................................19

2.5 Woodframe Structure of the NEESWood Benchmark and Capstone

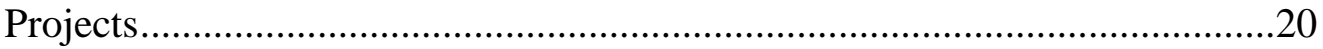

Chapter 3: Variables of Discontinuous Systems.........................................................24

3.1 Global Variables Related to Systems of Any Material .........................................24

3.2 Variables Related Specifically to Woodframe Shear Wall Structures...................25

3.3 Quantification of Variables Defining Systems Evaluated in Past Studies.............26

Chapter 4: Prototype Structure Design and Analysis ...............................................34

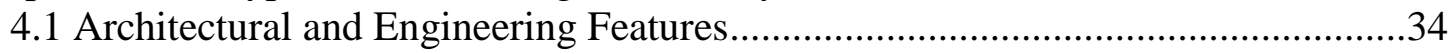

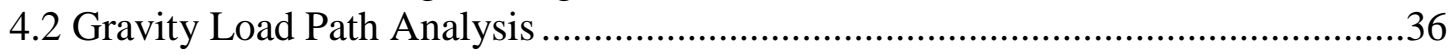

4.3 Lateral Load Path Analysis for Seismic Loads ....................................................38

4.4 Influence of the Code Penalties on Hardware Required for the

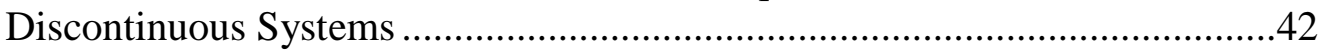

Chapter 5: Conclusions and Recommendations ......................................................48

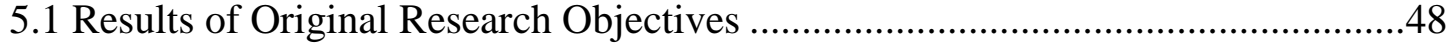

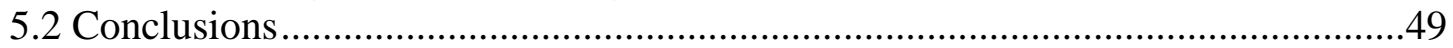

5.3 Recommendations for Engineering Practice.....................................................49

5.4 Recommendations for Continuation of Research ............................................50

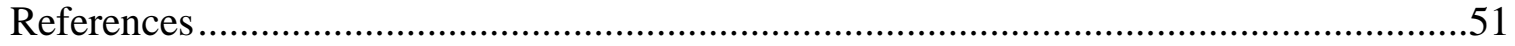




\section{TABLE OF CONTENTS CONT'D}

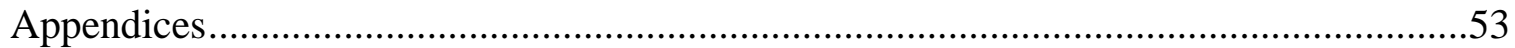

Appendix A: Blueprints of Prototype Structure.....................................................53

Appendix B: Load Path Analysis of Prototype Structure ..........................................65

Appendix C: RISA Software Analysis Results for Prototype Structure In-

Plane Type 4 Vertically Irregular LFRS 


\section{LIST OF TABLES}

Table 1. General Variables Related to LFRS of Any Material ...................................... 24

Table 2. Variables Related Specifically to Woodframe Shearwall Structures ................. 25

Table 3. General Variables Related to LFRS of The CUREe Fischer Project ................ 26

Table 4. Variables Related Specifically to Woodframe Shearwalls of the CUREe Fischer Project .......................................................................... 27

Table 5. General Variables Related to LFRS of The E-Defense Report ........................ 28

Table 6. Variables Related Specifically to Woodframe Shearwalls of the E-Defense Report

Table 7. General Variables Related to LFRS of The NEESWood Benchmark Project

Table 8. Variables Related Specifically to Woodframe Shearwalls of the NEESWood Benchmark Project

Table 9. General Variables Related to LFRS of The NEESWood Capstone Project

Table 10. Variables Related Specifically to Woodframe Shearwalls of the NEESWood Capstone Project 33

Table 11. Summary of Prototype Structure Gravity Design Loads 37

Table 12. Summary of Maximal Support Reactions, Uplift Forces, and Beam Forces of Prototype Structure Type 4 Vertically Irregular LFRS 


\section{LIST OF FIGURES}

Figure 1. ASCE 7-10 Table 12.3-1 - Horizontal Structural Irregularities........................

Figure 2. ASCE 7-10 Table 12.3-2 - Vertical Structural Irregularities .............................

Figure 3. ASCE 7-10 Commentary Figure 12.3-5 with McMullin Categorization of Vertical Irregularity Type 4 Elements

Figure 4. Selected Framing Plans and Elevations for Fischer Report .........................17

Figure 5. E-Defense Test Model B Retrofit Plan .....................................................20

Figure 6. Roof Level Framing Plan for the NEESWood Benchmark Test .....................22 


\section{Chapter 1: Introduction}

\subsection{Discontinuous Lateral Force Resisting Systems}

Discontinuous lateral-force-resisting systems (LFRS) are a type of LFRS in which the path of resistance to lateral forces does not continue directly to the foundation.

Specifically, a discontinuous LRFS will transfer lateral loading in a vertical element from one story to another while also transferring the load to another vertical element which is not located directly below the LFRS. Typically, a discontinuous LFRS can be categorized as in-plane or out-of-plane. In-plane discontinuous systems are defined as systems where the LRFS shifts in the plane of resistance. In an out-of-plane discontinuous LFRS, the shift is perpendicular to the plane of resistance. It is possible that an LFRS can be discontinuous both in-plane and out-of-plane.

Discontinuous systems are especially prevalent in lightweight, woodframe structures. These structures often include complex load paths due to the mixed function of upper and lower level stories in common single and multiple family residential structures. Because LFRS are critical for seismic resistance, several design penalties are required to meet the current International Building Code (IBC, 2012). The design penalties for discontinuous systems are severe, often requiring significantly larger connections and structural elements when designed. While the current American Society of Civil Engineers code (ASCE 7-10) defines when these penalties should be assigned, practicing engineers often are unclear about the precise application of such requirements when they finalize their structural design. Lack of transparency of the building code mixed with long-held misconceptions about wood design can result in significant 
variations in the design of a discontinuous LFRS. Significant research into woodframe construction over the past twenty years has resulted in much more rigorous data collection about these structures. This research includes a detailed review of past experiments to identify the extent and variety of discontinuous LFRS experiments that have been conducted. Through the identification of the existence and design of these systems, critical variables are defined. A parametric study of these variables is conducted to define test specimens for more detailed component-level testing.

\subsection{Problem Statement}

The basis of Capacity Design is that a ductile form of failure, such as shear failure of a wood shear wall, will occur if the system ever becomes overloaded. The rationale is that an overloaded system will then fail in a safe, predictable form. An analogy of this exists in home electrical supply design where a fuse/circuit breaker will fail if large amperages occur rather than having the potential failure being the overheating of an electrical circuit.

To achieve a Capacity Design failure, it is critical that all parts of the system be designed to have strengths larger than the chosen ductile form. Experience indicates that traditional wood shear wall systems are usually designed and built to result in the shear failure of the sheathing/nailing as the weak link to ensure ductile failure.

When considering the case of a discontinuous LFRS, elements of the system beyond the sheathing and nailing must resist seismic forces and gravity loads simultaneously, and failures may occur in members or components not directly involved in resisting seismic forces in manners unforeseen by engineers. These failure scenarios, and design 
philosophies intended to prevent them, are often not transparent in the writing of building codes and thus are easily overlooked by experienced and diligent engineers. Likewise, it is expected that there are municipalities and building departments that issue permits for the construction of structures where these discontinuous systems have not fully incorporated the building code required design penalties and load combinations.

Significant research into woodframe construction over the past twenty years has resulted in much more rigorous data collection about this category of structures. Three significant research initiatives (CUREe, 2005; NEES, 2013; E Defense, 2012) have utilized several full-scale, complete structure shake table experiments of woodframe structures. While these initiatives were not specifically focused on discontinuous systems, it is believed that some form of LFRS discontinuity was present in the tested structures.

In order to identify the extent and variety of discontinuous LFRS experiments that have been conducted, a detailed review of past experiments is necessary. Of particular interest is the definition of critical variables which define the existence and design of these systems. Upon the identification of these variables, a parametric study can be conducted to facilitate the design of test specimens, in addition to more detailed component-level testing.

While much data pertinent to LFRS studies are currently available online in structural engineering research repositories, the data are often chaotic and poorly defined. In addition, it is believed that no studies were particularly focused on discontinuous systems, so identifying these specimens poses a challenge, as does obtaining component 
level data for any discontinuous LFRS which is identified. However, once the experiments are identified, test data relevant to any discontinuous LFRS will be reviewed. In addition, this literature review combined with discussion with industry personnel should clarify the variables that are considered when these systems are designed. When considering the identification of discontinuous lateral force resisting systems as a basis of interest for investigating previous projects, initial report reviews were limited to those involving multi-story structures. Upon identifying the project studies containing testing of multi-story woodframe structures, further investigative scrutiny is required to determine whether or not discontinuous LFRS exist in these experiments. Finally, determining whether collection of data for the components of the discontinuous LFRS occurred is the ultimate point of review of these select project studies.

\subsection{Project Goals and Objectives}

The goal of the project is to improve understanding of the state-of-the-art as related to discontinuous LFRS of timber shear walls. Specifically, the project aims to do the following:

1. Collect drawings and technical data related to past full-scale woodframe experiments, particularly those conducted on shake tables.

2. Identify the existence of intended or unintended discontinuities in the LFRS of each specimen.

3. Identify critical variables that define the extent of discontinuity and the potential detrimental performance of the structure. 
4. Conduct parametric studies of the critical variables with the goal of defining up to three specimens that can be built and tested in the SJSU research lab.

5. Generate design examples which exhibit proper detailing of in-plane and out-ofplane discontinuous woodframe shearwall systems based on the requirements set forth in the ASCE 7-10.

\subsection{Scope of Work}

This project is a six semester-credit graduate thesis consisting predominantly of a literature review of past research and experiments relating to the study of Lateral Force Resisting Systems. This review is performed with the focus of determining whether discontinuous LFRS were present in the past experiments, and analyzing any experimental results related to the discontinuous systems, if available. In addition, a review of pertinent building codes will be performed to ultimately generate design examples of discontinuous LFRS based on a prototype two-story residential woodframe structure. The aim of the design examples are to provide a point of reference for the design and detailing of woodframe shearwalls with an out-of-plane offset horizontal irregularity, as well as woodframe shearwalls with an in-plane discontinuous vertical lateral force-resisting element irregularity. 


\section{Chapter 2: Literature Review}

\subsection{Building Codes Related to Discontinuous Structural Systems Intended to Resist Seismic Events}

The California Building Code (CBC) and the affiliated ASCE 7-10 use Capacity Design as the basic philosophy for seismic resistant design. The code significantly reduces the expected inertial forces that will develop in a major earthquake by providing a response modification factor, known as an R-value. The intrinsic level of damping and ductile yielding in a structure varies by type, and higher or lower R-values reflect this, with higher R-values being assigned to systems of higher ductility (McEntee, 2013). There are multiple reasons for reducing the inertial forces, but a primary goal is to define loads that can be combined with other forms of loads (dead, live, wind, etc) and use traditional design procedures such as allowable stress design, which is of common practice in the design of woodframe structures. The justification for this reduction in seismic force is the use of Capacity Design failure.

The ASCE treats the requirements for the seismic design of building structures in Chapter 12. Section 12.1.1 defines "basic requirements" pertaining to seismic design. Specifically, this section states that "building structures shall include complete lateral and vertical force-resisting systems capable of providing adequate strength, stiffness, and energy dissipation capacity to withstand the design ground motions within the prescribed limits of deformation and strength demand." As indicated in the code, design engineers are to produce a mathematical model of proposed structural systems intended to resist seismic forces which can demonstrate the building structures adequacy. Section 12.6 of 
the ASCE code describes “applicable procedures" by which to evaluate a structure's adequacy. Section 12.1.3 of the ASCE code suggests that a "continuous load path and interconnection" should be used to transfer forces between components of a LFRS. Although the ideal scenario of a continuous load path is often achieved, the function or usage of building structures does not always allow for continuity. Section 12.3 of the ASCE considers load path discontinuity as a type of structural configuration irregularity. These "configuration irregularities" are categorized as either "horizontal structural irregularities" or "vertical structural irregularities." Horizontal irregularities and vertical irregularities are defined in ASCE 7-10 Tables 12.3.1 and 12.3-2, respectively, and are shown in Figures 1 and 2.

\begin{tabular}{|c|c|c|c|}
\hline & Irregularity Type and Description & $\begin{array}{l}\text { Reference } \\
\text { Section }\end{array}$ & $\begin{array}{l}\text { Seismic Design } \\
\text { Category } \\
\text { Application }\end{array}$ \\
\hline la. & $\begin{array}{l}\text { Torsional Irregularity is defined to exist where the maximum story drift, computed including accidental } \\
\text { torsion, at one end of the structure transverse to an axis is more than } 1.2 \text { times the average of the story drifts at } \\
\text { the two ends of the structure. Torsional irregularity requirements in the reference sections apply only to } \\
\text { structures in which the diaphragms are rigid or semirigid. }\end{array}$ & $\begin{array}{c}12.3 .3 .4 \\
12.8 .4 .3 \\
12.7 .3 \\
12.12 .1 \\
\text { Table 12.6-1 } \\
\text { Section } 16.2 .2 \\
\end{array}$ & $\begin{array}{c}\mathrm{D}, \mathrm{E}, \text { and } \mathrm{F} \\
\mathrm{C}, \mathrm{D}, \mathrm{E}, \text { and } \mathrm{F} \\
\mathrm{B}, \mathrm{C}, \mathrm{D}, \mathrm{E} \text {, and } \mathrm{F} \\
\mathrm{C}, \mathrm{D}, \mathrm{E} \text {, and } \mathrm{F} \\
\mathrm{D}, \mathrm{E} \text {, and } \mathrm{F} \\
\mathrm{B}, \mathrm{C}, \mathrm{D}, \mathrm{E} \text {, and } \mathrm{F}\end{array}$ \\
\hline lb. & $\begin{array}{l}\text { Extreme Torsional Irregularity is defined to exist where the maximum story drift, computed including } \\
\text { accidental torsion, at one end of the structure transverse to an axis is more than } 1.4 \text { times the average of the story } \\
\text { drifts at the two ends of the structure. Extreme torsional irregularity requirements in the reference sections apply } \\
\text { only to structures in which the diaphragms are rigid or semirigid. }\end{array}$ & $\begin{array}{c}12.3 .3 .1 \\
12.3 .3 .4 \\
12.7 .3 \\
12.8 .4 .3 \\
12.12 .1 \\
\text { Table 12.6-1 } \\
\text { Section 16.2.2 }\end{array}$ & $\begin{array}{c}\mathrm{E} \text { and } \mathrm{F} \\
\mathrm{D} \\
\mathrm{B}, \mathrm{C} \text {, and } \mathrm{D} \\
\mathrm{C} \text { and } \mathrm{D} \\
\mathrm{C} \text { and } \mathrm{D} \\
\mathrm{D} \\
\mathrm{B}, \mathrm{C} \text {, and } \mathrm{D}\end{array}$ \\
\hline 2. & $\begin{array}{l}\text { Reentrant Corner Irregularity is defined to exist where both plan projections of the structure beyond a } \\
\text { reentrant corner are greater than } 15 \% \text { of the plan dimension of the structure in the given direction. }\end{array}$ & $\begin{array}{c}12.3 .3 .4 \\
\text { Table } 12.6-1\end{array}$ & $\begin{array}{l}\mathrm{D}, \mathrm{E} \text {, and } \mathrm{F} \\
\mathrm{D}, \mathrm{E} \text {, and } \mathrm{F}\end{array}$ \\
\hline 3. & $\begin{array}{l}\text { Diaphragm Discontinuity Irregularity is defined to exist where there are diaphragms with abrupt } \\
\text { discontinuities or variations in stiffness, including those having cutout or open areas greater than } 50 \% \text { of the } \\
\text { gross enclosed diaphragm area, or changes in effective diaphragm stiffness of more than } 50 \% \text { from one story to } \\
\text { the next. }\end{array}$ & $\begin{array}{c}12.3 .3 .4 \\
\text { Table } 12.6-1\end{array}$ & $\begin{array}{l}\mathrm{D}, \mathrm{E}, \text { and } \mathrm{F} \\
\mathrm{D}, \mathrm{E} \text {, and } \mathrm{F}\end{array}$ \\
\hline 4. & $\begin{array}{l}\text { Out-of-Plane Offsets Irregularity is defined to exist where there are discontinuities in a lateral force-resistance } \\
\text { path, such as out-of-plane offsets of the vertical elements. }\end{array}$ & $\begin{array}{c}12.3 .3 .4 \\
12.3 .3 .3 \\
12.7 .3 \\
\text { Table } 12.6-1 \\
16.2 .2\end{array}$ & $\begin{array}{l}\mathrm{D}, \mathrm{E}, \text { and } \mathrm{F} \\
\mathrm{B}, \mathrm{C}, \mathrm{D}, \mathrm{E} \text {, and } \mathrm{F} \\
\mathrm{B}, \mathrm{C}, \mathrm{D}, \mathrm{E} \text {, and } \mathrm{F} \\
\mathrm{D}, \mathrm{E}, \text { and } \mathrm{F} \\
\mathrm{B}, \mathrm{C}, \mathrm{D}, \mathrm{E} \text {, and } \mathrm{F}\end{array}$ \\
\hline 5. & $\begin{array}{l}\text { Nonparallel Systems-Irregularity is defined to exist where the vertical lateral force-resisting elements are not } \\
\text { parallel to or symmetric about the major orthogonal axes of the seismic force-resisting system. }\end{array}$ & $\begin{array}{c}12.5 .3 \\
12.7 .3 \\
\text { Table } 12.6-1 \\
\text { Section } 16.2 .2 \\
\end{array}$ & $\begin{array}{l}\mathrm{C}, \mathrm{D}, \mathrm{E}, \text { and } \mathrm{F} \\
\mathrm{B}, \mathrm{C}, \mathrm{D}, \mathrm{E} \text {, and } \mathrm{F} \\
\mathrm{D}, \mathrm{E}, \text { and } \mathrm{F} \\
\mathrm{B}, \mathrm{C}, \mathrm{D}, \mathrm{E} \text {, and } \mathrm{F}\end{array}$ \\
\hline
\end{tabular}

Figure 1. ASCE 7-10 Table 12.3-1 - Horizontal Structural Irregularities (ASCE) 


\begin{tabular}{|c|c|c|c|}
\hline & Irregularity Type and Description & $\begin{array}{l}\text { Reference } \\
\text { Section }\end{array}$ & $\begin{array}{l}\text { Seismic Design } \\
\text { Category } \\
\text { Application }\end{array}$ \\
\hline la. & $\begin{array}{l}\text { Stiffness-Soft Story Irregularity is defined to exist where there is a story in which the lateral stiffness is less than } \\
70 \% \text { of that in the story above or less than } 80 \% \text { of the average stiffness of the three stories above. }\end{array}$ & Table 12.6-1 & $\mathrm{D}, \mathrm{E}$, and $\mathrm{F}$ \\
\hline Ib. & $\begin{array}{l}\text { Stiffness-Extreme Soft Story Irregularity is defined to exist where there is a story in which the lateral stiffness } \\
\text { is less than } 60 \% \text { of that in the story above or less than } 70 \% \text { of the average stiffness of the three stories above. }\end{array}$ & $\begin{array}{c}12.3 .3 .1 \\
\text { Table } 12.6-1\end{array}$ & $\begin{array}{l}\mathrm{E} \text { and } \mathrm{F} \\
\mathrm{D}, \mathrm{E} \text {, and } \mathrm{F}\end{array}$ \\
\hline 2. & $\begin{array}{l}\text { Weight (Mass) Irregularity is defined to exist where the effective mass of any story is more than } 150 \% \text { of the } \\
\text { effective mass of an adjacent story. A roof that is lighter than the floor below need not be considered. }\end{array}$ & Table 12.6-1 & $\mathrm{D}, \mathrm{E}$, and $\mathrm{F}$ \\
\hline 3. & $\begin{array}{l}\text { Vertical Geometric Irregularity is defined to exist where the horizontal dimension of the seismic force-resisting } \\
\text { system in any story is more than } 130 \% \text { of that in an adjacent story. }\end{array}$ & Table 12.6-1 & $\mathrm{D}, \mathrm{E}$, and $\mathrm{F}$ \\
\hline 4. & $\begin{array}{l}\text { In-Plane Discontinuity in Vertical Lateral Force-Resisting Element Irregularity is defined to exist where an } \\
\text { in-plane offset of the lateral force-resisting elements is greater than the length of those elements or there exists a } \\
\text { reduction in stiffness of the resisting element in the story below. }\end{array}$ & $\begin{array}{c}12.3 .3 .3 \\
12.3 .3 .4 \\
\text { Table } 12.6-1\end{array}$ & $\begin{array}{l}\mathrm{B}, \mathrm{C}, \mathrm{D}, \mathrm{E} \text {, and } \mathrm{F} \\
\mathrm{D}, \mathrm{E} \text {, and } \mathrm{F} \\
\mathrm{D}, \mathrm{E}, \text { and } \mathrm{F}\end{array}$ \\
\hline $5 \mathrm{a}$. & $\begin{array}{l}\text { Discontinuity in Lateral Strength-Weak Story Irregularity is defined to exist where the story lateral strength is } \\
\text { less than } 80 \% \text { of that in the story above. The story lateral strength is the total lateral strength of all seismic-resisting } \\
\text { elements sharing the story shear for the direction under consideration. }\end{array}$ & $\begin{array}{c}12.3 .3 .1 \\
\text { Table } 12.6-1\end{array}$ & $\begin{array}{l}\mathrm{E} \text { and } \mathrm{F} \\
\mathrm{D}, \mathrm{E} \text {, and } \mathrm{F}\end{array}$ \\
\hline $5 b$. & $\begin{array}{l}\text { Discontinuity in Lateral Strength-Extreme Weak Story Irregularity is defined to exist where the story lateral } \\
\text { strength is less than } 65 \% \text { of that in the story above. The story strength is the total strength of all seismic-resisting } \\
\text { elements sharing the story shear for the direction under consideration. }\end{array}$ & $\begin{array}{l}\text { 12.3.3.1 } \\
\text { Table } 12.3 .6-1\end{array}$ & $\begin{array}{l}\mathrm{D}, \mathrm{E} \text {, and } \mathrm{F} \\
\mathrm{B} \text { and } \mathrm{C} \\
\mathrm{D}, \mathrm{E} \text {, and } \mathrm{F}\end{array}$ \\
\hline
\end{tabular}

Figure 2. ASCE 7-10 Table 12.3-2 - Vertical Structural Irregularities (ASCE)

Discontinuous LFRS are defined in the code as those lateral force resisting systems that do not have a load path continuing directly to the foundation, such as is the case with an offset shear wall. Per McMullin (2016), the assemblies of the in-plane or out of plane discontinuous systems (irregularity Type 4 of both ASCE Table 12.3-2 and 12.3-1, respectively) can be divided into four categories:

Item A) - the lateral force resisting system that resists seismic load but does not continue directly to the foundation,

Item B) - the supporting system below that transfers the horizontal shear from the discontinuous system to the foundation,

Item C) - the supporting system below that transfers the vertical effects (overturning) of the seismic load to the foundation, and

Item D) - the connections between Items A and B, as well as between Items A and C. 
The ASCE code does not identify, require or detail any aspects of Items B, C and D to ensure that they will have a ductile failure. Thus from the code perspective, the only failure that is ensured to be ductile is the sheathing failure of Item A. Hence, the only way that the system can be ensured to fail in a ductile mode is by requiring items outside of Item A to be able to resist the largest forces that may occur before the shear walls fail. In the interest of seeking ductile failure, the code uses the omega factor or "overstrength" factor $\left(\Omega_{0}\right)$ to predict the largest amount of inertial force that can be generated in the structure in a major earthquake. Figure 3 shown below highlights the McMullin (2016) categorization for a Type 4 vertical structural irregularity.

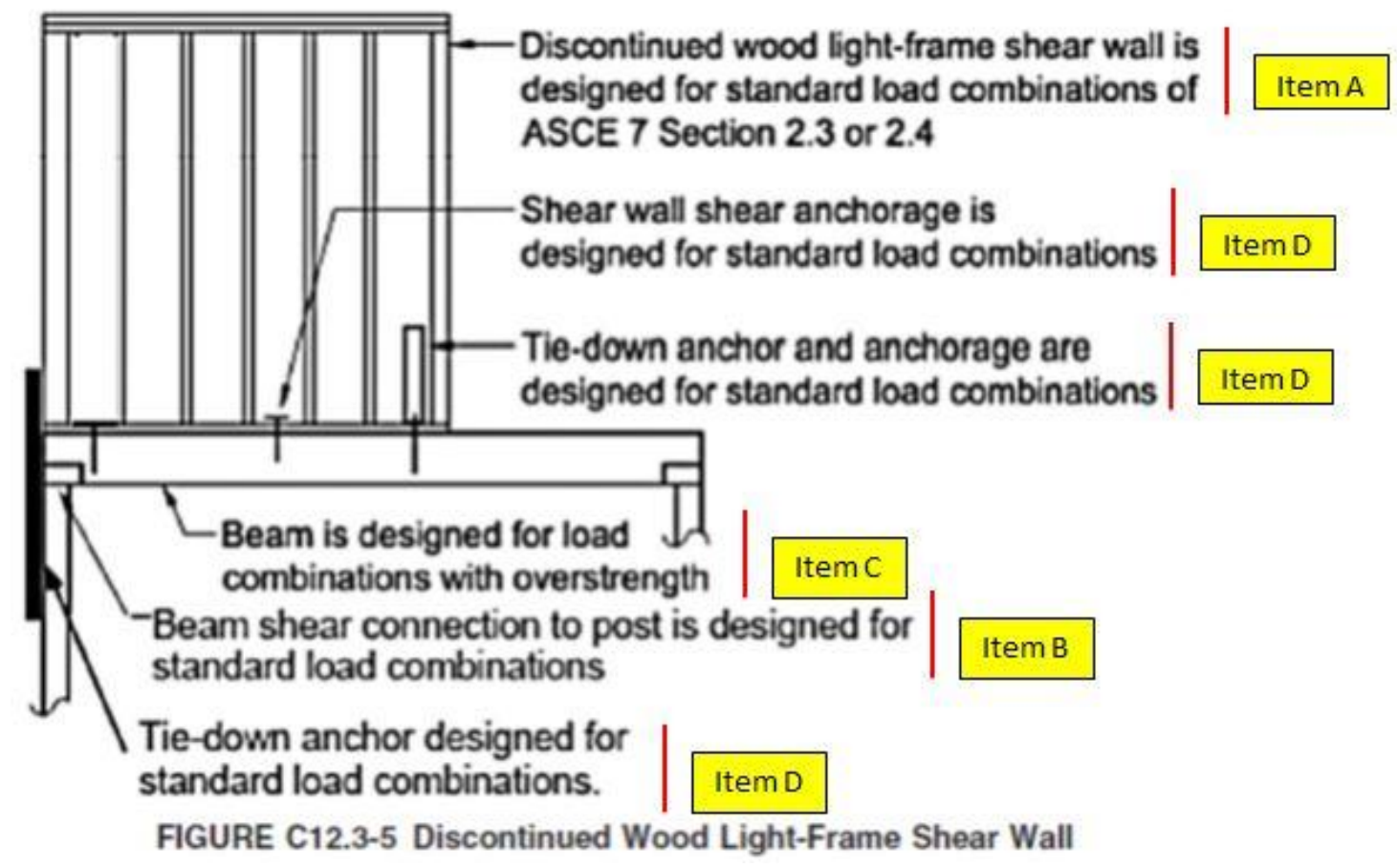

Figure 3. ASCE 7-10 Commentary Figure 12.3-5 with McMullin Categorization of Vertical Irregularity Type 4 Elements (ASCE, McMullin) 
The cost of engineering and construction is considered by the committees that write and approve the code. The ASCE Commentary explicitly states that Item D does not need to consider this omega factor, likely because these connections are similar to the arrangement that would be used if no discontinuity exists. Likewise, the commentary explicitly states that Item B does not need to be designed using the omega factor, likely because of the extra capacity and redundancy that is inherent in diaphragms and the associated horizontal shear transfer mechanisms.

With regards to Item $\mathrm{C}$ however, the wording of the first paragraph of ASCE Commentary section C12.3.3.3 clearly uses the term "vertical load" as being in need of the overstrength factor. The code does not separate the components of Item $\mathrm{C}$ from each other. The commentary does not state or imply that only the beam resisting the overturning loads be designed with the overstrength factor $\left(\Omega_{\mathrm{o}}\right)$. As noted by S.K. Ghosh (2014) in his article concerning the major changes regarding seismic design between the ASCE 7-05 code and the current ASCE 7-10, some clarification has been attempted regarding vertical structural irregularity type 4. The ASCE 7-05 defined an in-plane vertical irregularity or discontinuity in a vertical lateral force resisting element to be present when the offset of these elements was larger than the length of the elements, or when a reduction in stiffness was present in the resisting element of the story below (Ghosh, 2014). According to Ghosh (2014), the length stipulation of the ASCE 7-05 is an unconservative one, in addition to the fact that reduced stiffness below a lateral force resisting element does not necessarily imply an in plane discontinuity. The ASCE 7-10 attempts to clarify and simplify the definition of a type 4 vertical structural irregularity. 
As defined in ASCE 7-10, this irregularity type exists "where there is an in-plane offset of a vertical seismic force-resisting element resulting in overturning demands on a supporting beam, column, truss, or slab."

An example of the criticality of this design feature would be the situation when a beam supporting a discontinuous shear wall has enough dead load to barely counterbalance the effect of uplift due to design-level forces on the wall. In this case, no additional hardware would be required or likely installed to ensure the beam remains seated on the supporting post. In this scenario, if a moderate earthquake produces inertial forces $50 \%$ higher than the design load, it is very likely the beam will then break free from the post allowing the upper portions of the structure to overturn.

The treatment of the design penalties for irregular or discontinuous LFRS is contained within Chapter 12 of the ASCE 7-10. Specifically, Sections 12.4 and 12.14 provide the pertinent details for determining the demand on systems with the irregularities established in ASCE 7-10 Tables 12.3-1 and 12.3-2. Section 12.4, titled "Seismic Load Effects and Combinations", provides load combinations to be used in the general design of structures for seismic effects.

Section 12.14, titled "Simplified Alternative Structural Design Criteria for Simple Bearing Wall or Building Frame Systems”, is analogous to Section 12.4 but its use is limited to specific bearing wall or building frame type structural systems. These structures are defined in ASCE 7-10 Table 12.14-1. Referring to this table in conjunction with Table 12.2-1, the reader can note the significantly lesser number of structure types listed in Table 12.14-1. Table 12.14-1 is further simplified from Table 12.2-1 in that there 
is no list of specific system overstrength factors $\left(\Omega_{0}\right)$ based on structure type.

Additionally, the deflection amplification factor $(\mathrm{Cd})$ seen in Table 12.2-1 is not present

in 12.14-1. Finally, structural system limitations are listed only by seismic design category (SDC) permissibility in 12.14-1, whereas Table 12.2-1 imposes system type limitations based on SDC as well as maximum allowable structure heights. The major simplification of ASCE 7-10 Section 12.14 lies in the fact that the determination of story drift and a modal response spectrum analysis are not required. The reader is directed to ASCE 7-10 Sections 12.8 .6 and 12.9 for code treatment of story drift determination and modal response spectrum analysis.

\subsection{The Overstrength Factor $\Omega_{\mathrm{o}}$}

The concept of overstrength in structural design has been a topic of study by engineers for decades. Initial studies of overstrength such as that by Humar and Rahgozar (1996) originated as a means to quantify the ability of structures to resist forces greater than that for which they were designed. When discussing structural overstrength, this generally refers to the resistance of lateral forces imposed on a structure due to seismic loading. This perceived overstrength was attributed to the structure as reserve strength due to structural ductility not accounted for in typical elastic design methodologies, excess strength available in structural connections, and a structures inherent ability to dissipate forces through structural and non-structural elements. Early studies of overstrength and its sources struggled to make clear how this factor could be reliably quantified, and ensuing versions of building codes have directed designers away from determining the available overstrength in a structure. Now, current building codes 
use the term overstrength as a factor to amplify design forces imparted on structural elements which serve to resist lateral (seismic) forces. In particular, the overstrength factor $\Omega_{0}$, is applied as a design penalty to lateral force resisting elements which contain "structural irregularities" defined by the ASCE.

Original studies of structural overstrength were attempting to quantify reserve strength and the sources of this extra strength (Humar and Rahgozar, 1996). Problems with the quantification of this overstrength stemmed from the fact that the sources of this extra available strength were unreliable, and not always predictable. Despite the difficulties in quantifying this overstrength, the fact that many structures remained standing and functional after exposure to lateral forces exceeding those which they were designed for made clear that this reserve strength existed. Humar and Rahgozar (1996) categorized probable sources of overstrength in four ways:

1. Factors that involve uncertainty, such as the difference between a structural elements actual capacity and that which it was calculated for.

2. Factors that cannot be accounted for due to lack of knowledge, such as the use of conservative calculation procedures.

3. Factors that can be but are not commonly accounted for in calculating capacity, such as code prescribed minimum design loads.

4. Factors related to simplification in design procedure, including the use of singledegree-of-freedom design response spectra in conjunction with a multi-degree-offreedom structural design. 
While these factors certainly exist, the way to use the knowledge of them generated varying view points on how to apply them, with some varying interpretations and applications such as decreasing design loads, or increasing allowable strengths of structural elements. The evolution of the term overstrength and its usage in practice should steer engineers away from making unruly or unwarranted design decisions, but this is not to say that confusion and debate no longer exist as they pertain to the application of overstrength in its current capacity.

The current ASCE code uses the overstrength factor $\Omega_{\mathrm{o}}$ as a sort of design penalty which applies to structural components of systems used to resist lateral forces that contain structural irregularities. The code defines many different types of irregularities for which this factor should apply in design. An example of a structural irregularity is a lateral force resisting element which does not contain a direct load path to the foundation, such as exists in a discontinuous shear wall.

According to the National Earthquake Hazard Reduction Program (NEHRP), a majority of structures exhibit greater lateral force resistance than standardized analysis procedures would show, by levels of 30 to 100 percent (NEHRP, 2013). Though this acknowledgment is made, NEHRP also states that:

Most structural systems have some components or limit states that cannot provide reliable inelastic response or energy dissipation. Such components or limit states must be designed considering that the actual forces in the structure will be larger than those at first significant yield. The standard specifies an overstrength factor, $\Omega_{\mathrm{o}}$, to amplify the prescribed forces for use in design of such components or limit states. This specified overstrength factor is neither an upper nor a lower bound; it is simply an approximation specified to provide a nominal degree of protection against undesirable behavior. (p.112) 
One basis of thought in regards to applying the overstrength factor $\Omega_{\mathrm{o}}$ to irregular systems stems from the fact that the "reserve strength" inherent in regular type systems is less likely available in an irregular one. The lacking of a clear load path and redundancy in such systems implies a lesser capacity to resist inertial forces, and the $\Omega_{0}$ factor is utilized as a means to make up for this.

Although the current overstrength paradigm as it pertains to structural design has shifted from a more theoretical and difficult-to-quantify phenomena toward a system by which to increase the strength of non-ideal (yet not impractical or ineffective) lateral force resisting systems, the current design methodologies are not free of flaws or avenues for varying interpretations. The ASCE's treatment of the issue has generated confusion and debate amongst industry personnel on how to properly apply the factor, and to what extent it needs to be applied to structural systems. With new methods come new problems and applications by which to interpret and solve them, and the use of the overstrength factor $\Omega_{\mathrm{o}}$ in current structural engineering practice is no exception. 


\subsection{Woodframe Structures of the CUREe-Caltech Fischer Woodframe Project}

The Consortium of Universities for Research in Earthquake Engineering or CUREeCaltech Woodframe Project was a cooperative analytical and empirical study performed by engineers and researchers from various academic institutions. The purpose of the project was to study topics in earthquake engineering and in turn provide the engineering community with methods to increase safety of woodframe structures during seismic events and mitigate structural damage due to earthquakes. Also known as The Earthquake Hazard Mitigation of Woodframe Construction project, the consortium received funding through FEMA and California state grants until its dissolution in 2016.

A particular study of the CUREe project in W-06: Shake Table Tests of a Two-Story Woodframe House (Fischer et al, 2001) was found to contain discontinuous shearwalls occuring in multiple instances. This experimental structure was designed and built to be in the fashion of current era California style construction for single family residential structures. The design intent was to be relatively simple, and not include the use of any floor cantilevers or roof offsets. Despite the simplistic nature of this structure, five instances of discontinuous LFRS were identified. Two cases of discontinuity exist on the second floor level of the experimental structure along grid lines A and C (exterior walls, north and south faces) which are symmetrical and make up four of the 5 total instances. The fifth instance exists on an interior wall along grid line 5. These discontinuities come in the form of vertical in-plane offsets (ASCE Table 12.3-2, type 4). Figure 4 shows framing plan views of the Fischer project structure, as well as framing elevations at the locations of the discontinuous LFRS of the structure, respectively. 

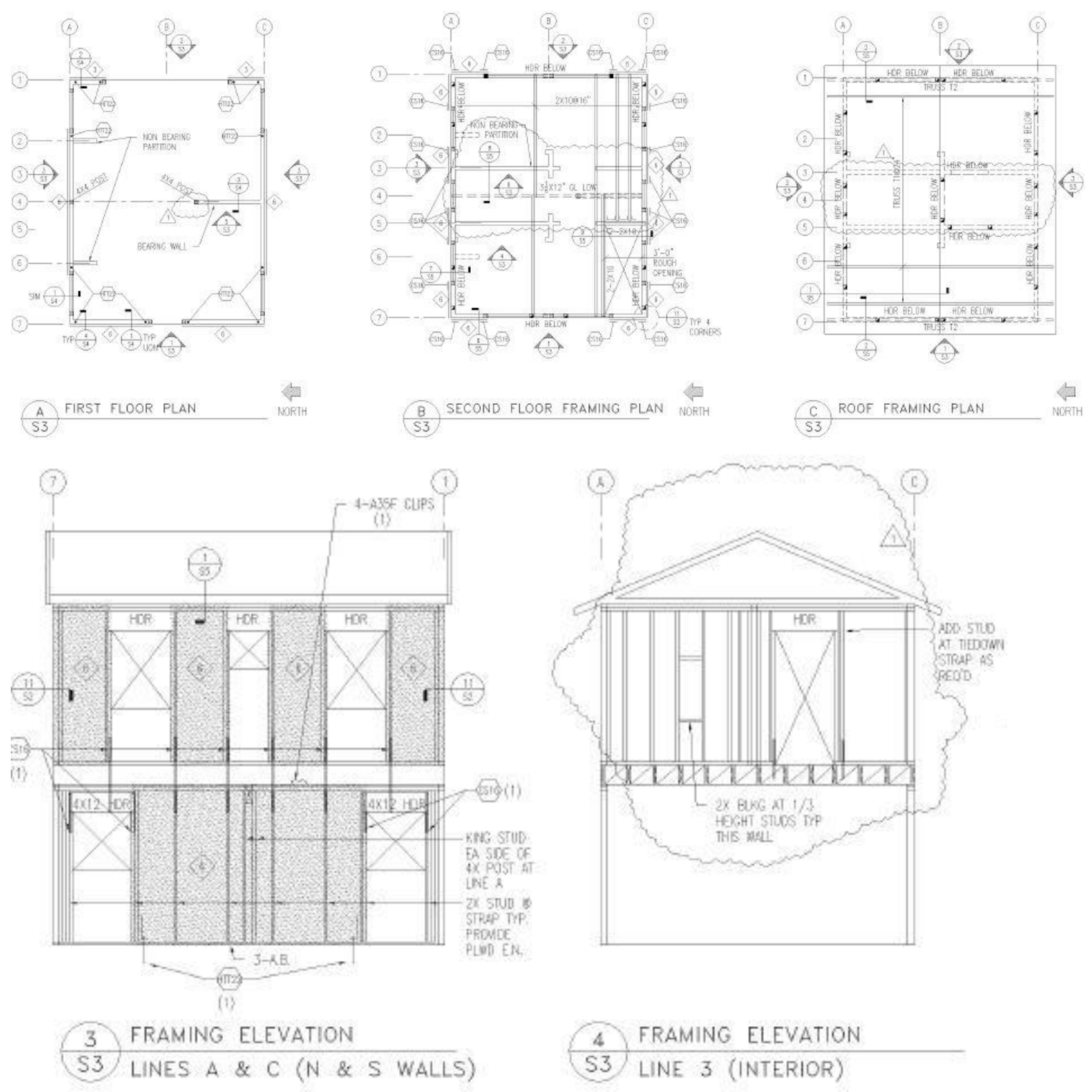

Figure 4. Selected Framing Plans and Elevations for Fischer Report (CUREe)

In the framing elevations of Figure 4, LFRS discontinuities are evident. In 3/S3, we see CS16 straps from end shearwalls attached to window headers below, as well as a hold down strap to blocking between floor joists to the left and right of the second story door opening shown in the section 4/S3. Both of these arrangements represent in-plane offset, vertical irregularities (ASCE 7-10 Table 12.3-2, Type 4). 
Review of the report produced for this CUREe project by Fischer yielded no mention of the discontinuous systems which existed in the experimental test structure. The lack of any mention of the present LFRS discontinuities is assumed to be due to the fact that studying these types of systems was not the focus of this project, along with the fact that the discontinuities are minor in nature. The discontinuities of this project are deemed "minor" in that the structural elements below the discontinuities would not likely cause total structural failure in the case of a component level failure. Appendices L and M of the Fischer report provide collected data for hold down and anchor bolt forces imparted during testing phases, and hold down anchor and strap uplift deflections, respectively. Reviewing this data with specific attention paid to areas of the LFRS discontinuities revealed that maximal uplift forces were not occurring at the discontinuous locations. Unfortunately, hold down forces were only measured for ground level devices, and not for strap devices used to anchor the discontinuous portions of the structures. Although actual force readings weren't present for these items, uplift deflection values were available. This data showed minimal deflections at the discontinuity locations. Maximal deflections and hold down forces are seen at the shearwall boundaries of the ground level LFRS, and peak values for these items existed at the corners of the structure, where load path continuity is fully available from roof level to foundation level.

What can be concluded from the architectural and structural drawings available in Appendix A of the Fischer report is that it appears that the detailing and strapping of the discontinuous walls appears to have been done in a manner which can adequately transfer loads due to lateral shaking to the foundation. Although indirect, the fact that the load 
paths are completed likely is responsible for the low uplift deflections measured at discontinuity locations.

\subsection{Woodframe Structures of the E-Defense Projects}

Between 2002 and 2007 the Japanese Ministry of Education, Culture, Sports, Science, and Technology conducted a five year research project titled, "A Special Project for Earthquake Disaster Mitigation in Urban Areas." The aim of this project was to test wood frame residential structures which were built by traditional Japanese construction methods before the advent of the current Japanese building code, as well as to test these structures with modern seismic retrofits in place (Nakamura, 2008). The tests were to be conducted at E-Defense in Japan, a test facility which houses the world's largest shake table used for the simulation of seismic events. Ultimately, over ten structures were tested against the ground motion of the devastating 1995 earthquake in Kobe, Japan.

The review of the report of the E-Defense tests provided minimal insight into the actual current standards of seismic resistant design, but the limited plan views provided for retrofitted structures tested generally aligned with practices similar to that of standard American woodframe design. Shown in Figure 5, a retrofit plan for Model B of the EDefense test structures contains locations of added plywood sheathing, wooden bracing, and hold down devices. The hold down device types are not specified, but tension strap devices are used to resist overturning forces at the second story level, with hold down devices at the foundation level. 


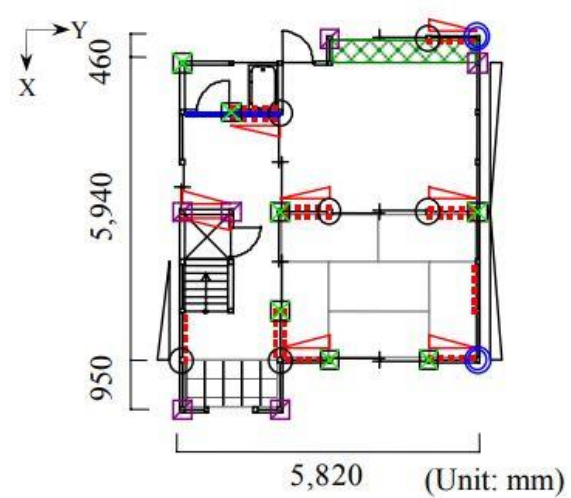

(a) First story

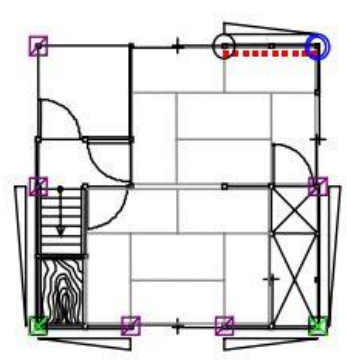

Seismic reinforcement added on the original timber framework

$\simeq$ Wood brace

...... Plywood

Additional wooden beam

$\triangle \times \times \times$ Reinforcement of lean-to roof

(C) Hold down fastener

$\triangle \square$ Metal Joint

Figure 5. E-Defense Test Model B Retrofit Plan (E-Defense)

Utilizing the legend at the right of Figure 5, it appears that there is a discontinuous shearwall along the rear of the structure's second story. Plywood sheathing, wood bracing, and hold down devices at each end of the wall are shown. There are no apparent walls below the second floor shearwall in question, and no first floor hold down devices are shown directly below the upper wall in plan-view.

\subsection{Woodframe Structures of the NEESWood Benchmark and Capstone Projects}

The Network for Earthquake Engineering Simulation (NEES) NEESWood projects were a collective effort between the University at Buffalo, State University of New York, Colorado State University, University of Delaware, Rensselaer University, and Texas A\&M University. The goal of the NEESWood projects was to better understand the factors which affect the seismic performance of woodframe structures, and to develop a “direct displacement based seismic design philosophy." As current building codes limit woodframe structures to be low-rise (four stories or less), NEESWood sought to validate efficient woodframe design and construction methods for mid-rise structures in moderate to high seismic zones (Christovasilis et al., 2009). 
The NEESWood Benchmark project test building was the largest woodframe structure tested on a shake table at the time of the project (Christovasilis et al., 2009). Based on 1980's through 1990's California style construction, the Benchmark Project structure was designed as a two-story townhouse with 1800 square feet of floor space.

The NEESWood Benchmark project report is thorough in its treatment of architectural and structural plans. Review of these plans in the appendices of the report revealed two instances of discontinuous LFRS. One instance can be seen at the second story along grid line 1 and between lines $\mathrm{C}$ and $\mathrm{D}$ of the structural framing plans. This discontinuous braced shearwall panel sits above the ends of cantilevered floor framing members. This arrangement represents a Type 4 out-of-plane horizontal irregularity. The second discontinuous LFRS exists at the opposite end of the structure's second floor along grid line 6 . In this case, there are two second story shearwalls which extend beyond the shearwalls of the first story below, and have boundaries which sit on the glulam garage door opening header member. This arrangement represents a Type 4 in-plane vertical irregularity. It should be mentioned that neither of the two cases of discontinuous shearwalls which are present contain any hold down devices for the purpose of resisting overturning forces. Figure 6 shows roof level framing plans, where the locations of the two identified discontinuous LFRS can be seen.

Unfortunately, no mention of LFRS discontinuity exists throughout the entirety of the NEESWood Benchmark project report. Any key words or phrases which would imply the treatment of these discontinuous LFRS considered the applicable overstrength factors or load combinations are absent. In addition, no gravity or lateral load path analysis in 
support of the structural design is provided in the report, so it is assumed that overstrength analysis was not performed, or was not mentioned due to the project not being focused on such analysis.

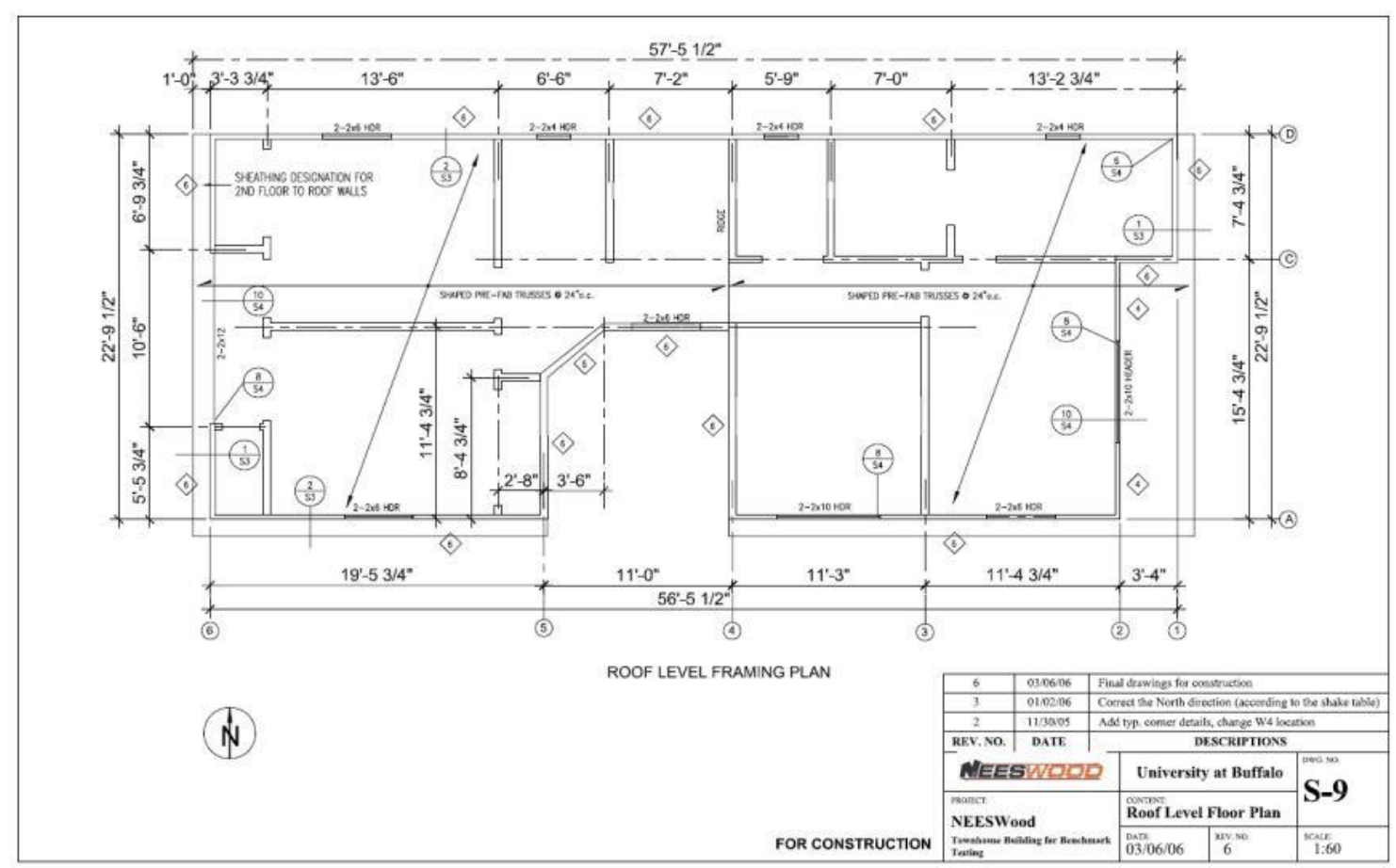

Figure 6. Roof Level Framing Plan for the NEESWood Benchmark Project (NEES)

The NEESWood Capstone project was the culminating experimental structure of the NEESWood series of projects. The Benchmark structure tests served as a basis for the experimental procedures used in the testing of the Capstone structure (van de Lindt et al., 2010). The Capstone project structure was a six-story, mid-rise woodframe structure, designed to mimic a multi-family residential structure, as often seen in mid-rise apartment buildings. At the time of experimental testing (and still today), the Capstone 
structure represented the largest woodframe structure ever tested on a shake table. The tests were conducted at the previously mentioned E-Defense facility in Japan.

Compared to the more complex architectural layout of the Benchmark structure, the Capstone structure was more regular in nature. The floorplans on each story level are nearly identical, facilitating continuous load paths from the roof level down to the foundation level. Bearing wall lines and shearwall lines are coincident with one another. No discontinuous LFRS were identified for the NEESWood Capstone structure.

Although the Capstone project provided a plethora of empirical and visual data related to the seismic response of mid-rise woodframe structures, the focus of this project was not directed at studying discontinuous LFRS. 


\section{Chapter 3: Variables of Discontinuous Systems}

\subsection{General Variables Related to Systems of Any Material}

Section 3.1 lists variables which are related to discontinuous LFRS, regardless of the materials utilized in the construction. Table 1 lists the variables considered. Information reported herein is based on allowable stress design (ASD) principles.

\section{Table 1}

General Variables Related to LFRS of Any Material

\begin{tabular}{|c|c|c|c|}
\hline Raw Data & Variable & Units & Notes \\
\hline Number of stories above discontinuity & $\mathrm{Na}$ & - & - \\
\hline Height of structure roof & $\mathrm{Hr}$ & $\mathrm{mm}(\mathrm{ft})$ & $\begin{array}{l}\text { Height of roof above } \\
\text { foundation }\end{array}$ \\
\hline $\begin{array}{l}\text { Height of structure above } \\
\text { discontinuity }\end{array}$ & $\mathrm{Ha}$ & $\mathrm{mm}(\mathrm{ft})$ & - \\
\hline Height of story above discontinuity & ha & $\mathrm{mm}(\mathrm{ft})$ & $\begin{array}{l}\text { Top of floor to top of } \\
\text { floor }\end{array}$ \\
\hline $\begin{array}{l}\text { Length of structural system above } \\
\text { discontinuity }\end{array}$ & $\mathrm{La}$ & $\mathrm{mm}(\mathrm{ft})$ & - \\
\hline Structural system above discontinuity & $\mathrm{Sa}$ & - & $\begin{array}{l}\text { Use ASCE table to } \\
\text { define }\end{array}$ \\
\hline Structural system below discontinuity & $\mathrm{Sb}$ & - & $\begin{array}{l}\text { Use ASCE table to } \\
\text { define }\end{array}$ \\
\hline System Overstrength Factor & $\Omega_{0}$ & - & $\begin{array}{l}\text { Use ASCE table to } \\
\text { define }\end{array}$ \\
\hline $\begin{array}{l}\text { Type of discontinuity (in-plane or out- } \\
\text { of-plane or both) }\end{array}$ & - & - & - \\
\hline $\begin{array}{l}\text { Offset distance (in-plane or out-of- } \\
\text { plane) }\end{array}$ & - & $\mathrm{mm}(\mathrm{ft})$ & - \\
\hline Other irregularities in structure & - & - & - \\
\hline Type of study & - & - & $\begin{array}{l}\text { Shake Table, Computer } \\
\text { model, etc. }\end{array}$ \\
\hline $\begin{array}{l}\text { Type of gravity support below } \\
\text { discontinuity }\end{array}$ & - & - & $\begin{array}{c}\text { Bearing wall, } \\
\text { Cantilever Beam, etc. }\end{array}$ \\
\hline
\end{tabular}




\subsection{Variables Related Specifically to Woodframe Shearwall Structures}

Section 3.2 lists variables which are related specifically to woodframe discontinuous

LFRS. Table 2 lists the variables considered. Information reported herein is based on allowable stress design (ASD) principles.

Table 2

Variables Related Specifically to Woodframe Shearwall Structures

\begin{tabular}{|c|c|c|c|}
\hline Raw Data & Variable & Units & Notes \\
\hline $\begin{array}{l}\text { Strength of wall above } \\
\text { discontinuity }\end{array}$ & qa & plf & - \\
\hline $\begin{array}{l}\text { Strength of wall below } \\
\text { discontinuity }\end{array}$ & $q b$ & plf & - \\
\hline $\begin{array}{l}\text { Anchorage of wall at } \\
\text { discontinuity }\end{array}$ & - & & Type of anchorage hardware \\
\hline Anchor strength at discontinuity & - & $\mathrm{lb}$ & $\begin{array}{c}\text { Allowable strength of anchorage } \\
\text { hardware }\end{array}$ \\
\hline Overturning resistance load path & - & - & $\begin{array}{l}\text { Discontinuous posts are straped to } \\
\text { beams or to columns }\end{array}$ \\
\hline $\begin{array}{l}\text { Orientation of floor framing } \\
\text { below to discontinuous walls }\end{array}$ & - & - & Parallel or perpendicular or skewed \\
\hline $\begin{array}{l}\text { Shear strength of diaphragm } \\
\text { below discontinuous walls }\end{array}$ & qd & plf & Allowable strength \\
\hline $\begin{array}{l}\text { Support system designed with } \\
\text { overstrength factor? }\end{array}$ & - & - & Yes or No \\
\hline $\begin{array}{l}\text { Support system designed with } \\
\text { omega factor all the way to } \\
\text { foundation? }\end{array}$ & - & - & Yes or No \\
\hline Construction date of structure & - & Year & $\begin{array}{l}\text { Date of construction of existing } \\
\text { structures or for research study the } \\
\text { estimated date that the structure is } \\
\text { intended to represent }\end{array}$ \\
\hline Wall type above discontinuity & - & - & $\begin{array}{l}\text { Perforated shear wall, shear walls, } \\
\text { perforated walls }\end{array}$ \\
\hline
\end{tabular}




\subsection{Quantification of Variables Defining Systems Evaluated in Past Studies}

Section 3.3 utilizes the tables from Sections 3.1 and 3.2 in Tables 3 - 10 to quantify the variables previously listed for past studies which were evaluated for the existence of discontinuous LFRS. Tables for each of the projects discussed in Chapter 2 are included in this section. Wall and anchorage strengths listed in the following tables are allowable values, not ultimate strength figures.

Table 3

General Variables Related to LFRS of The CUREe Fischer Project

\begin{tabular}{|c|c|c|c|}
\hline Raw Data & Variable & Units & Notes \\
\hline $\begin{array}{l}\text { Number of stories above } \\
\text { discontinuity }\end{array}$ & $\mathrm{Na}$ & - & 1 \\
\hline Height of structure roof & $\mathrm{Hr}$ & $\mathrm{ft}$-in & 19’-10” \\
\hline $\begin{array}{l}\text { Height of structure above } \\
\text { discontinuity }\end{array}$ & $\mathrm{Ha}$ & $\mathrm{ft}$-in & 10’-9” \\
\hline $\begin{array}{l}\text { Height of story above } \\
\text { discontinuity }\end{array}$ & ha & $\mathrm{ft}$-in & $8^{\prime}-1 ”$ \\
\hline $\begin{array}{l}\text { Length of structural system above } \\
\text { discontinuity }\end{array}$ & $\mathrm{La}$ & $\mathrm{ft}$-in & $3 ’-0 ”$ \\
\hline $\begin{array}{l}\text { Structural system above } \\
\text { discontinuity }\end{array}$ & $\mathrm{Sa}$ & - & WSP LFRS \\
\hline $\begin{array}{l}\text { Structural system below } \\
\text { discontinuity }\end{array}$ & $\mathrm{Sb}$ & - & WSP LFRS \\
\hline System Overstrength Factor & $\Omega_{\mathrm{o}}$ & - & 2.5 \\
\hline $\begin{array}{l}\text { Type of discontinuity (in-plane or } \\
\text { out-of-plane or both) }\end{array}$ & - & - & In-plane \\
\hline $\begin{array}{l}\text { Offset distance (in-plane or out-of- } \\
\text { plane) }\end{array}$ & - & ft-in & $1 '-6 ”$ \\
\hline Other irregularities in structure & - & - & N/A \\
\hline Type of study & - & - & Shake Table Experiment \\
\hline $\begin{array}{l}\text { Type of gravity support below } \\
\text { discontinuity }\end{array}$ & - & - & Bearing wall \\
\hline
\end{tabular}


Table 4

Variables Related Specifically to Woodframe Shearwalls of the CUREe Fischer Report

\begin{tabular}{|c|c|c|c|}
\hline Raw Data & Variable & Units & Notes \\
\hline $\begin{array}{l}\text { Strength of wall above } \\
\text { discontinuity }\end{array}$ & qa & plf & 440 (Nominal) \\
\hline $\begin{array}{l}\text { Strength of wall below } \\
\text { discontinuity }\end{array}$ & $\mathrm{qb}$ & plf & 440 (Nominal) \\
\hline $\begin{array}{l}\text { Anchorage of wall at } \\
\text { discontinuity }\end{array}$ & & & Simpson Strong Tie CS16 Strap \\
\hline Anchor strength at discontinuity & - & $\mathrm{lb}$ & 1705 \\
\hline Overturning resistance load path & & & $\begin{array}{c}\text { Discontinuous posts are straped to } \\
\text { headers }\end{array}$ \\
\hline $\begin{array}{l}\text { Orientation of floor framing } \\
\text { below discontinuous walls }\end{array}$ & - & - & Parallel \\
\hline $\begin{array}{l}\text { Shear strength of diaphragm } \\
\text { below discontinuous walls }\end{array}$ & qd & plf & 640 (Nominal) \\
\hline $\begin{array}{l}\text { Support system designed with } \\
\text { overstrength factor? }\end{array}$ & - & - & No \\
\hline $\begin{array}{l}\text { Support system designed with } \\
\text { omega factor all the way to } \\
\text { foundation? }\end{array}$ & - & - & No \\
\hline Construction date of structure & - & Year & Mid to Late 1900's \\
\hline Wall type above discontinuity & - & - & WSP Shearwall \\
\hline
\end{tabular}


Table 5

General Variables Related to LFRS of The E-Defense Report

\begin{tabular}{|c|c|c|c|}
\hline Raw Data & Variable & Units & Notes \\
\hline $\begin{array}{l}\text { Number of stories above } \\
\text { discontinuity }\end{array}$ & $\mathrm{Na}$ & - & 1 \\
\hline Height of structure roof & $\mathrm{Hr}$ & $\mathrm{mm}$ & 5405 \\
\hline $\begin{array}{l}\text { Height of structure above } \\
\text { discontinuity }\end{array}$ & $\mathrm{Ha}$ & $\mathrm{mm}$ & 5405 \\
\hline Height of story above discontinuity & ha & $\mathrm{mm}$ & 2645 \\
\hline $\begin{array}{l}\text { Length of structural system above } \\
\text { discontinuity }\end{array}$ & $\mathrm{La}$ & $\mathrm{mm}$ & 1940 \\
\hline $\begin{array}{l}\text { Structural system above } \\
\text { discontinuity }\end{array}$ & $\mathrm{Sa}$ & - & WSP LFRS with wooden bracing \\
\hline $\begin{array}{l}\text { Structural system below } \\
\text { discontinuity }\end{array}$ & $\mathrm{Sb}$ & - & WSP LFRS with wooden bracing \\
\hline System Overstrength Factor & $\Omega_{\mathrm{o}}$ & - & 2.5 \\
\hline $\begin{array}{l}\text { Type of discontinuity (in-plane or } \\
\text { out-of-plane or both) }\end{array}$ & - & - & In-plane \\
\hline $\begin{array}{l}\text { Offset distance (in-plane or out-of- } \\
\text { plane) }\end{array}$ & - & $\mathrm{mm}$ & 460 \\
\hline Seismic coefficient of building & - & - & unknown \\
\hline $\begin{array}{l}\text { Seismic coefficient at location of } \\
\text { discontinuity }\end{array}$ & - & - & unknown \\
\hline Other irregularities in structure & - & - & N/A \\
\hline Type of study & - & - & Shake Table Experiment \\
\hline $\begin{array}{l}\text { Type of gravity support below } \\
\text { discontinuity }\end{array}$ & - & - & Bearing wall \\
\hline
\end{tabular}


Table 6

Variables Related Specifically to Woodframe Shearwalls of the E-Defense Report

\begin{tabular}{|c|c|c|c|}
\hline Raw Data & Variable & Units & Notes \\
\hline $\begin{array}{l}\text { Strength of wall above } \\
\text { discontinuity }\end{array}$ & qa & plf & unknown \\
\hline $\begin{array}{l}\text { Strength of wall below } \\
\text { discontinuity }\end{array}$ & $q b$ & plf & unknown \\
\hline $\begin{array}{l}\text { Anchorage of wall at } \\
\text { discontinuity }\end{array}$ & - & - & unknown \\
\hline Anchor strength at discontinuity & - & $\mathrm{lb}$ & unknown \\
\hline Overturning resistance load path & - & - & $\begin{array}{l}\text { Discontinuous posts are straped to } \\
\text { framing below }\end{array}$ \\
\hline $\begin{array}{l}\text { Orientation of floor framing } \\
\text { below discontinuous walls }\end{array}$ & - & - & unknown \\
\hline $\begin{array}{l}\text { Shear strength of diaphragm } \\
\text { below discontinuous walls }\end{array}$ & qd & plf & unknown \\
\hline $\begin{array}{l}\text { Support system designed with } \\
\text { overstrength factor? }\end{array}$ & - & - & No \\
\hline $\begin{array}{l}\text { Support system designed with } \\
\text { omega factor all the way to } \\
\text { foundation? }\end{array}$ & - & - & No \\
\hline Construction date of structure & - & Year & 2006, 1974 \\
\hline Wall type above discontinuity & - & - & Shearwall \\
\hline
\end{tabular}




\section{Table 7}

General Variables Related to LFRS of The NEESWood Benchmark Project

\begin{tabular}{|c|c|c|c|}
\hline Raw Data & Variable & Units & Notes \\
\hline $\begin{array}{l}\text { Number of stories above } \\
\text { discontinuity }\end{array}$ & $\mathrm{Na}$ & - & 1 \\
\hline Height of structure roof & $\mathrm{Hr}$ & ft-in & 17'-2”' (both) \\
\hline $\begin{array}{l}\text { Height of structure above } \\
\text { discontinuity }\end{array}$ & $\mathrm{Ha}$ & $\mathrm{ft}$-in & 17 '-2” (both) \\
\hline Height of story above discontinuity & ha & $\mathrm{ft}$-in & 8'-1 (both) \\
\hline $\begin{array}{l}\text { Length of structural system above } \\
\text { discontinuity }\end{array}$ & $\mathrm{La}$ & ft-in & $7^{\prime}-43 / 4^{\prime \prime}, 6^{\prime}-93 / 4^{\prime \prime}$ \\
\hline $\begin{array}{l}\text { Structural system above } \\
\text { discontinuity }\end{array}$ & $\mathrm{Sa}$ & - & WSP Shearwall \\
\hline $\begin{array}{l}\text { Structural system below } \\
\text { discontinuity }\end{array}$ & $\mathrm{Sb}$ & - & WSP Shearwall \\
\hline System Overstrength Factor & $\Omega_{\mathrm{o}}$ & - & 2.5 or 3 \\
\hline $\begin{array}{l}\text { Type of discontinuity (in-plane or } \\
\text { out-of-plane or both) }\end{array}$ & - & - & Both \\
\hline $\begin{array}{l}\text { Offset distance (in-plane or out-of- } \\
\text { plane) }\end{array}$ & - & $\mathrm{ft}$-in & 6'-83/4", 3'-5”' \\
\hline Other irregularities in structure & - & - & Reentrant Corner Irregularity \\
\hline Type of study & - & - & Shake Table Experiment \\
\hline $\begin{array}{l}\text { Type of gravity support below } \\
\text { discontinuity }\end{array}$ & - & - & $\begin{array}{l}\text { Cantilever Floor Framing w/ bearing } \\
\text { wall, } \\
\text { Post and Beam over Garage Opening }\end{array}$ \\
\hline
\end{tabular}


Table 8

Variables Related Specifically to Woodframe Shearwalls of the NEESWood Benchmark Project

\begin{tabular}{|c|c|c|c|}
\hline Raw Data & Variable & Units & Notes \\
\hline $\begin{array}{l}\text { Strength of wall above } \\
\text { discontinuity }\end{array}$ & qa & plf & 260 \\
\hline $\begin{array}{l}\text { Strength of wall below } \\
\text { discontinuity }\end{array}$ & $\mathrm{qb}$ & plf & 380 \\
\hline $\begin{array}{l}\text { Anchorage of wall at } \\
\text { discontinuity }\end{array}$ & - & & Sole Plate Nailing \\
\hline Anchor strength at discontinuity & - & $\mathrm{lb}$ & N/A \\
\hline Overturning resistance load path & - & - & First Floor Hold Down Devices \\
\hline $\begin{array}{l}\text { Orientation of floor framing } \\
\text { below discontinuous walls }\end{array}$ & - & - & Perpendicular \\
\hline $\begin{array}{l}\text { Shear strength of diaphragm } \\
\text { below discontinuous walls }\end{array}$ & qd & plf & 1420 \\
\hline $\begin{array}{l}\text { Support system designed with } \\
\text { overstrength factor? }\end{array}$ & - & - & Unknown \\
\hline $\begin{array}{l}\text { Support system designed with } \\
\text { omega factor all the way to } \\
\text { foundation? }\end{array}$ & - & - & Unknown \\
\hline Construction date of structure & - & Year & 1980’s-1990’s \\
\hline Wall type above discontinuity & - & - & $\begin{array}{c}\text { Typical wood stud framed, WSP } \\
\text { bracing }\end{array}$ \\
\hline
\end{tabular}


Table 9

General Variables Related to LFRS of The NEESWood Capstone Project

\begin{tabular}{|c|c|c|c|}
\hline Raw Data & Variable & Units & Notes \\
\hline $\begin{array}{l}\text { Number of stories above } \\
\text { discontinuity }\end{array}$ & $\mathrm{Na}$ & - & N/A \\
\hline Height of structure roof & $\mathrm{Hr}$ & $\mathrm{mm}$ & 20198 \\
\hline $\begin{array}{l}\text { Height of structure above } \\
\text { discontinuity }\end{array}$ & $\mathrm{Ha}$ & $\mathrm{mm}$ & N/A \\
\hline $\begin{array}{l}\text { Height of story above } \\
\text { discontinuity }\end{array}$ & ha & $\mathrm{mm}$ & N/A \\
\hline $\begin{array}{l}\text { Length of structural system above } \\
\text { discontinuity }\end{array}$ & $\mathrm{La}$ & $\mathrm{mm}$ & N/A \\
\hline $\begin{array}{l}\text { Structural system above } \\
\text { discontinuity }\end{array}$ & $\mathrm{Sa}$ & - & N/A \\
\hline $\begin{array}{l}\text { Structural system below } \\
\text { discontinuity }\end{array}$ & $\mathrm{Sb}$ & - & N/A \\
\hline System Overstrength Factor & $\Omega_{\mathrm{o}}$ & - & 3 \\
\hline $\begin{array}{l}\text { Type of discontinuity (in-plane or } \\
\text { out-of-plane or both) }\end{array}$ & - & - & N/A \\
\hline $\begin{array}{l}\text { Offset distance (in-plane or out-of- } \\
\text { plane) }\end{array}$ & - & $\mathrm{mm}$ & N/A \\
\hline Other irregularities in structure & - & - & N/A \\
\hline Type of study & - & - & Shake Table Experiment \\
\hline $\begin{array}{l}\text { Type of gravity support below } \\
\text { discontinuity }\end{array}$ & - & - & N/A \\
\hline
\end{tabular}


Table 10

Variables Related Specifically to Woodframe Shearwalls of the NEESWood Capstone Project

\begin{tabular}{lcccc}
\hline Raw Data & Variable & Units & Notes \\
\hline $\begin{array}{l}\text { Strength of wall above } \\
\text { discontinuity }\end{array}$ & qa & plf & N/A \\
$\begin{array}{l}\text { Strength of wall below } \\
\text { discontinuity }\end{array}$ & qb & plf & N/A \\
$\begin{array}{l}\text { Anchorage of wall at } \\
\text { discontinuity }\end{array}$ & & & N/A \\
$\begin{array}{l}\text { Anchor strength at discontinuity } \\
\text { Overturning resistance load path }\end{array}$ & - & lb & N/A \\
$\begin{array}{l}\text { Orientation of floor framing } \\
\text { below discontinuous walls }\end{array}$ & - & - & Hold Down Straps and Hold Down \\
$\begin{array}{l}\text { Shear strength of diaphragm } \\
\text { below discontinuous walls }\end{array}$ & qd & plf & N/A \\
$\begin{array}{l}\text { Support system designed with } \\
\text { overstrength factor? }\end{array}$ & - & - & N/A \\
$\begin{array}{l}\text { Support system designed with } \\
\text { omega factor all the way to } \\
\text { foundation? }\end{array}$ & - & - & No \\
$\begin{array}{l}\text { Construction date of structure } \\
\text { Wall type above discontinuity }\end{array}$ & - & Year & - & No \\
\hline
\end{tabular}




\section{Chapter 4: Prototype Structure Design and Analysis}

\subsection{Architectural and Engineering Features}

The prototype structure designed for the purpose of this project is a two-story single family residence. The prototype structure is a three bedroom, three bathroom plus office home totaling 1800 square feet, with a Dutch gable style roof. In the interest of analytical simplicity, the footprint of the structure was chosen to be square with equal length and width.

As is common in residential floor plans, the layout of second story walls and ground floor walls was arranged in a manner that necessitates an in-plane discontinuous LFRS along the main center bearing line of the structure. In addition, the second floor is offset by two feet from the first floor perimeter walls at grid lines A and A.1, as well as C and C.1. These kinds of offsets are occasionally required to meet code enforced setback regulations, or to achieve a particular desired architectural appearance. As these offsets occur at perimeter walls which are used as braced wall lines, we encounter the situation of out-of-plane LFRS discontinuity. While many architects are aware of the extra design complexities involved when structural irregularities such as in-plane or out-of-plane LFRS discontinuities exist, these code-penalized irregularities often cannot be avoided while simultaneously meeting the needs and desires of the client, and the regulations imposed by local building codes.

The chosen structural elements of the prototype home to resist gravity loads are typical of modern timber construction for single family type residences. The roof system consists of trusses at 24" on-center spacing, with 5/8" CDX plywood sheathing nailed 
with $10 \mathrm{~d}$ nails at 6 " on-center along panel edges, and 12" on-center field nailing. The bearing walls consist of $2 \times 4$ studs at 16 " on-center, with a plate height of $8^{\prime}-0$ '. Headers at window or door openings are typically 4x Douglas-Fir No.1 lumber.

The second story floor system consists of engineered lumber in the form of 11-7/8" Ijoists and $3 / 4$ " plywood subfloor sheathing. More and more frequently, I-joists are specified in timber construction, as they are able to achieve longer spans per unit weight, are straighter and more consistent than traditional sawn lumber, and are much lighter and more user friendly for workers to install in the field.

Finally, the foundation is a 5" thick slab on grade with \#4 rebar spaced at 16 " oncenter in both the transverse and longitudinal directions. The slab is lain over $3 / 4$ " drain rock and vapor barrier. The perimeter footing is a continuous strip footing typical of two story residential construction on normal soil conditions, 16" wide and 18" deep below grade surface. There is also a central grade beam of the same dimensions coincident with the center bearing wall line. The continuous perimeter footing and central grade beam are reinforced with two \#4 longitudinal bars at the top and bottom of the footing.

The LFRS of the prototype structure consists of plywood braced shear wall panels. As noted previously, in-plane and out-of-plane discontinuities are present at interior and exterior braced wall lines, respectively. The shear wall sheathing considered for the prototype structure is $1 / 2$ " Struct. 1 . While $1 / 2$ " gypsum board has been considered in determining the gravity and seismic weights of the structure, the gypsum board is neglected for the purpose of determining the LFRS's load resisting capacity. The architecture of the prototype structure was approached from the standpoint of maximizing 
lateral forces imparted on the LFRS without exceeding the capacity of $1 / 2$ " Struct. 1 plywood and restricting nail spacing to a minimum of 3" on center at panel edges. This approach was desirable for the purpose of developing a two-story full scale model similar to the in-plane discontinuous LFRS of grid line B, which could be feasibly constructed and tested in the Structural Engineering Lab of SJSU.

\subsection{Gravity Load Path Analysis}

The gravity load path analysis of the prototype structure generally follows from ASCE 7-10, with basic load combinations for allowable stress design (ASD) provided in Chapter 2, section 4 (2.4.1 Basic Combinations) with dead loads as defined in Chapter 3, and live loads per Chapter 4, section 3. The reader is directed to Appendix B for the gravity load path analysis for the prototype structure.

Load combinations prescribed in ASCE 7-10 2.4.1 used in the gravity analysis include dead loads $(D)$, live loads $(L)$ and roof live loads $\left(L_{r}\right)$. Load combination (LC) 1, 2, 3 , and 4 from section 2.4 .1 are considered in this gravity analysis. LC1 considers only $D$, LC2 considers $D+L$, LC3 considers $D+L_{r}$, while LC4 considers $D+0.75 L+0.75 L_{r}$. The rationale is to consider all applicable load combinations, and to apply the combination which imparts the most unfavorable effect on the member being analyzed. It is convenient to analyze the effects of each load source separately, so the loads can be applied to each load combination independently of one another. The benefits of this approach become apparent when more complex load combinations are required for special design scenarios (such as those for discontinuous LFRS). Some of the combinations such as LC4 take into consideration the probability or likelihood that 
maximal live loading across all levels of the structure is low. For this reason, reduction factors may be applied by the engineer when using such load combinations.

The remaining load combinations (5-8) are not considered, as snow $(S)$, wind $(W)$, or earthquake $(E)$ loads are not considered in this gravity analysis, and these load sources are included in those remaining load combinations. In Chapter 4, section 4 (4.4) of this report, basic combinations for ASD with overstrength factor include both $D, L$, and $E$ loads are considered. The reader is directed to 4.4 for more information regarding these combinations. In Chapter 4, section 3 (4.3) of this report, only $D$ and $E$ loads are considered as part of the lateral load path analysis for the prototype structure. Table 11 below summarizes the gravity loads utilized in the analysis of the prototype structure. The reader is directed to Appendix B for a list of material unit weights used to compile the loads of Table 11.

Table 11

Summary of Prototype Structure Gravity Design Loads

Dead Load Live Load

\begin{tabular}{lrl}
\hline Roof & $12 \mathrm{psf}$ & $20 \mathrm{psf}$ \\
Exterior Walls & $10 \mathrm{psf}$ & N/A \\
Interior Walls & $8 \mathrm{psf}$ & N/A \\
Floor & $14 \mathrm{psf}$ & $40 \mathrm{psf}$ \\
\hline
\end{tabular}




\subsection{Lateral Load Path Analysis for Seismic Loads}

The procedure used to laterally analyze the prototype structure follows the equivalent lateral force method. The equivalent lateral force method, which is outlined in ASCE 7-10 Section 12.8, involves distributing the design seismic forces by floor or story level, and analyzing the effects of these forces by applying them to the structure as static loads. The portion of the overall seismic force applied at a certain floor is determined by considering the height of each floor relative to the base of the structure and its overall weight contribution to the structure. Because the effects of seismic forces are typically most severe at the higher points of a structure, the equivalent lateral force method takes this into consideration, and requires the designer to apply larger forces to the higher floor levels. The diaphragm that exists at each floor level in the form of sheathed roof or floor framing are used in the analysis to apply the lateral seismic forces to the vertical elements intended to resist these forces. These vertical elements may also be diaphragms such as a woodframe shearwall, or individual structural members such as a beam support post.

Determining the design seismic forces for a structure with the equivalent lateral force method allows a designer to quickly and relatively easily demonstrate the demand of a structure to resist earthquake forces and exhibit ductility in the event of failure. Structures meeting specific criteria may be analyzed using the simplified analysis procedure. ASCE 7-10 Section 12.14.1 illustrates the criteria for using the simplified procedure. With the convenience of this method comes a lesser degree of precision, and as such, building codes limit the types of structures for which the method may be used. Structures 
containing irregularity, high occupancy risk category, or those with more than three story levels are not generally permitted to be analyzed using the simplified procedure.

In the case of the project prototype structure, the simplified procedure is an acceptable form of analysis despite the fact that the structure contains multiple system irregularities. The in-plane and out-of-plane shearwall offsets which exist in the prototype would typically disqualify a structure from being analyzed using the simplified procedure, but an exception in the ASCE code allows simplification when the structure in question is of light-frame construction and does not exceed two stories in height. The code stipulates that any framing member which supports the upper wall of an irregular or discontinuous LFRS must be designed for seismic force effects due to overturning amplified by a factor which varies by structure type, and in this case is equal to 2.5 . The reader is directed to Chapter 4 , Section 4 (4.4) of this document for discussion of this amplification factor and the related load combinations using overstrength.

Critical steps in determining the design seismic forces for the prototype structure include determining the seismic base shear, $V$, the seismic response coefficient of the structure, $C_{s}$, and the vertical distribution factor, $C_{v x}$. These three critical values facilitate the usage of the equivalent lateral force procedure. The base shear is calculated as follows:

$$
V=C_{s} W
$$

where

$W=$ the effective seismic weight of the structure per ASCE 7-10 12.7.2. 
The minimum seismic response coefficient $C_{s}$, is determined by ASCE 7-10 equation 12.8.6:

$$
C_{s}=\frac{0.5 S_{1}}{\left(\frac{R}{I}\right)}
$$

where

$S_{1}=$ the spectral response acceleration parameter at a period of 1 second as defined in ASCE 7-10 Section 11.4.1,

$R=$ the response modification factor from ASCE 7-10 Table 12.2-1, and

$I=$ the occupancy importance factor determined in accordance with ASCE 7-10

Section 11.5.1.

The vertical distribution factor, $C_{v x}$, is given by:

$$
C_{v x}=\frac{w_{x} h_{x}^{k}}{\sum_{i=1}^{n} w_{i} h_{i}^{k}}
$$

where

$w_{i}$ and $w_{x}=$ the portion of the total effective seismic weight of the structure $(W)$

located or assigned to Level $i$ or $x$,

$h_{i}$ and $h_{x}=$ the height from the base to Level $i$ or $x$,

$k=$ an exponent related to the structure period.

With these three values defined and determined, the lateral force induced at any level is determined as:

$$
F_{x}=C_{v x} V
$$

where 
$V=$ total design lateral force or shear at the base of the structure.

Using $F_{x}$, the unit load applied statically across the appropriate story level diaphragm in pounds per square foot can be determined.

$$
\text { unit load }=\left(F_{x} /_{A}\right) \times 1000
$$

where

$A=$ the story plan area in $\mathrm{ft}^{2}$.

Once the unit story load is determined, this load may be applied uniformly along the length of the structure, either in the longitudinal or transverse direction, to determine the magnitude of force which must be resisted by the lateral force resisting elements of each respective story.

In light-frame wooden structures such as that of the prototype structure considered in this report, floor or roof diaphragms may exhibit considerable levels of in-plane deformation. For computational convenience, these membranes are often idealized as flexible diaphragms. The calculation of design shear forces imparted on lateral force resisting elements becomes analogous to calculating support reactions of uniformly loaded simply supported beams when a flexible diaphragm approach is utilized. The lateral loads imparted uniformly across the horizontal diaphragm (floor or roof) are simply distributed to the vertical resisting elements by tributary area. The ASCE 7-10 permits the use of rigid or flexible diaphragm idealization for diaphragms of wood structural panels (WSP) in one- and two-family light-frame construction. 
Section 12.3.1.1 of the ASCE 7-10 provides conditions for which flexible diaphragm analysis is acceptable. Items b and c of 12.3.1.1 state that "one- and two-family dwellings" (item b) and structures of light frame construction where there are no concrete (or similar material) panels placed over WSP diaphragms that are greater than 1 1/2" $(38 \mathrm{~mm})$ in thickness, as well as the requirement for "each line of vertical elements of the seismic force resisting system to comply with the allowable story drift of Table 12.12-1 (item c). The prototype structure for this project meets these requirements, and therefore the analysis of the prototype structure utilizes a flexible diaphragm approach. The reader is directed to Appendix B for the full lateral load path analysis.

The results obtained through the lateral load path analysis are critical for the design of the structure's LFRS. Accurately determining the demand on the LFRS facilitates the safest and most efficient design decisions. As is the case for the prototype structure which contains various system irregularities, the code imparts design penalties on elements of these systems. These design penalties typically come at the cost of more robust structural elements, and more usage of costly hardware. A discussion of these code penalties follows in Chapter 4 Section 4 (4.4).

\subsection{Influence of the Code Penalties on Hardware Required for Discontinuous Systems}

In order to best discuss the influence of code penalties on structural elements, including framing members and connecting hardware, it is useful to discuss applicable load combinations which are used to determine the code prescribed demand used to 
design these items. The ASCE provides two sets of load combinations based on different design methodologies: "Strength Design" and "Allowable Stress Design" (ASD).

In practice, woodframe structure design typically employs ASD. The following discussion is based on the load combinations for the ASD approach.

While basic load combinations for ASD are treated in ASCE 7-10 Section 2.4, Sections 12.4.3.3 and 12.14.3.2 of ASCE 7-10 treat load combinations in which overstrength $\left(\Omega_{\mathrm{o}}\right)$ is applied. Comparing the load combinations of Section 2.4 and 12.4.3.3 which contain earthquake loads offers initial insight as to the extent of the code penalties on systems designed with the overstrength factor. Basic ASD load combinations $5,6 \mathrm{~b}$, and 8 of Section 2.4 are as follows:

$$
\begin{aligned}
& \text { 5. } D+(0.6 W \text { or } 0.7 E) \\
& \text { 6b. } D+0.75 L+0.75(0.7 E)+0.75 S
\end{aligned}
$$

$$
\text { 8. } 0.6 D+0.7 E
$$

It is immediately noticeable that each of these load combinations offers a reduction of earthquake loads $(E)$, as well as the other load sources. These loads or load effects, which are determined through a gravity and lateral load path analysis, are allowed to be reduced when combined using ASD load combinations as mentioned in Section 2.1 of this document. These reduction factors included in the load combinations above consider the likelihood of loading scenarios. For example, in the above load combination $6 \mathrm{~b}$, it is unlikely that maximal design live loading, earthquake loading, and snow loading will simultaneously occur, therefore, these load cases are allowed a reduction. 
ASCE Section 12.4.3.2 offers the following ASD load combinations with the overstrength factor, which follow from the basic ASD load combinations above:

$$
\begin{aligned}
& \text { 5. }\left(1.0+0.14 S_{D S}\right) D+H+F+0.7 \Omega_{o} Q_{E} \\
& \text { 6. }\left(1.0+0.105 S_{D S}\right) D+H+F+0.525 \Omega_{o} Q_{E}+0.75 L+0.75\left(L_{r} \text { or } S \text { or } R\right) \\
& \text { since } E=\Omega_{o} Q_{E}+0.2 S_{D S} D \text {, and } \\
& \text { 8. }\left(0.6-0.14 S_{D S}\right) D+0.7 \Omega_{o} Q_{E}+H \\
& \text { since } E=\Omega_{o} Q_{E}-0.2 S_{D S} D
\end{aligned}
$$

These load combinations simultaneously account for horizontal and vertical effects of earthquake forces. This is achieved by increasing the dead load factor $D$ to consider vertically downward earthquake effects as seen in combinations 5 and 6 (Ghosh 2014). The opposite scenario is considered in combination 8 to simulate vertical earthquake forces through the reduction of the dead load factor (Ghosh 2014). The inclusion of $S_{D S}$ intends to make the increase or reduction of the dead load a function of the seismicity of the structure site (Ghosh 2014). The magnitude of $S_{D S}$, which is the short period design spectral acceleration for a site, varies by location. A higher value indicates greater site seismicity. These additive and counteractive load combinations both hold implications for the structural members which support discontinuous systems, and the hardware which makes the connections between these members. The additive combinations typically have the most influence on the structural members in support of the discontinuous system (Item C of Chapter 2 Section 1). For example, the demand on a beam or column which typically serves to support vertical gravity loads may greatly increase if overturning effects impart vertical downward force on the beam or column. Considering the 
counteractive load combination, hardware used for resisting uplift forces is influenced (Item D of Chapter 2 Section 1) As mentioned in Chapter 2 the scenario of a beam to column connection experiencing considerable uplift due to overturning could be at risk of separation in cases of large seismic events. Care must be taken by designers to follow the amplified loads in both the additive and counteractive cases all the way to the foundation of a structure to ensure the capacity of all vertical support members and connecting hardware below a discontinuity are adequate. The adequacy of these components is critical for the prevention of non-ductile failures of the structure (McEntee 2013).

In the case of a light-frame timber structure which utilizes WSP as the form of lateral bracing, the overstrength factor $\Omega_{0}$ is equal to 3 . When a structure contains flexible diaphragms such as that of the project prototype structure, footnote "g" of ASCE 7-10 Table 12.2-1 states that "where the tabulated value of the overstrength factor, $\Omega_{0}$, is greater than or equal to $2 \frac{1}{2}, \Omega_{0}$ is permitted to be reduced by subtracting the value of $1 / 2$ for structures with flexible diaphragms." This offers a slight break in regards to the imposed design penalties for structures like that of the project prototype, and gives an overstrength factor $\Omega_{0}$ equal to $2 \frac{1}{2}$. Diaphragms of irregular systems and their connections are prescribed a $25 \%$ increase in design forces, although this is not required when designing using overstrength load combinations of ASCE 7-10 Section 12.4.3 (Malone, 2016). 
Where design loads are determined using amplified seismic forces, the code allows the designer to apply a $20 \%$ increase in the allowable stress a given member may undergo when considering the overstrength load combinations. This increase in allowable stress may also be applied to devices which connect members, such as hold down devices and connector straps. Furthermore, in the design of woodframe structures based on the National Design Specification (NDS), a load duration factor of 1.6 can be applied to members and connectors of systems when their design load combinations include seismic forces. This $60 \%$ increase in allowable stress takes into consideration the fact that the time of application (load duration) of the loads or forces is short, and as a building material, wood has relatively high strength under short duration loading.

Utilizing the ASD load combinations with overstrength for the project prototype structure produces a factor of 1.75 increase on seismic forces for combinations 5 and 8 of Section 12.4.3.2 of the ASCE 7-10, and a 1.3125 increase factor for combination 6. Where the assumption of $S_{D S}$ is equal to unity, as is made for the prototype structure, dead load effects are increased by a factor of 1.14 for combination 5 , and a factor of 1.105 for combination 6 . In the case of combination 8 , the dead load sees a reduction factor of 0.46 . Combining these factors with the allowable stress increase of $20 \%$ for connector allowable loads still produces the net effect of a higher demand, but the increased demand is not as severe as simply multiplying the non-overstrength loads by $\Omega_{\mathrm{o}}$. Table 12 contains maximum uplift, download, and bending values for the in-plane, vertically discontinuous LFRS of the project prototype structure. These results highlight 
the implications of applying overstrength load combinations for the design of LFRS elements and connections versus the basic ASD load combinations.

Table 12

Summary of Maximal Support Reactions, Uplift Forces, and Beam Forces of Prototype Structure Type 4 Vertically Irregular LFRS

\begin{tabular}{lccc}
\hline Load Combination: & Basic ASD & $\begin{array}{c}\text { ASD with } \\
\text { Overstrength }\end{array}$ & $\%$ Increase \\
\hline Support Reaction & $7520 \mathrm{lbs}$ & $9932 \mathrm{lbs}$ & $32 \%$ \\
Uplift Force & $2599 \mathrm{lbs}$ & $5934 \mathrm{lbs}$ & $128 \%$ \\
$\begin{array}{l}\text { Beam Bending } \\
\text { Moment }\end{array}$ & $7588 \mathrm{lb}-\mathrm{ft}$ & $11835 \mathrm{lb}-\mathrm{ft}$ & $56 \%$ \\
Beam Shear Force & $4060 \mathrm{lbs}$ & $5844 \mathrm{lbs}$ & $44 \%$
\end{tabular}

As shown in Table 12, each critical force for the design of connections and selection of framing members are significantly affected by applying load combinations which contain the overstrength factor. In the case of the system analyzed for the prototype structure, the most significant demand increases come in the form of uplift forces and beam bending moment. Demand increases of this magnitude would result in the specification of more robust connection hardware, stronger supportive framing members, and higher constructed costs. The extent of the demand increase will vary based on the seismicity of the project location in actual practice. 


\section{Chapter 5: Conclusions and Recommendations}

\subsection{Results of Original Research Objectives}

The goal at the outset of the project was to improve understanding of the state-of-theart as related to discontinuous LFRS of timber shear walls. Through the collection and review of past projects containing full-scale woodframe structure shake table experiments, drawings and technical data (where available), various instances of LFRS discontinuity were discovered. Unfortunately, practically no discussion of these discontinuities existed in the writing of the project reports. The author believes that this is due to the discontinuities being unintentionally included in the designs of the respective test structures. Additionally, the general design philosophy of the test structures typically utilized conventional bracing arrangements due to the relatively low complexity of the structures.

Under the guidance of Kurt McMullin, critical variables were determined and used to assist in the evaluation of reviewed experimental structures. These variables were broken down into categories applicable to structures of any material, as well as those specific to woodframe construction methods. These variables were considered in the design and evaluation of a hypothetical prototype structure. This prototype structure was designed under the guidance of Kurt McMullin for the purpose of analyzing a structure which contains various types of discontinuous LFRS, as well as to provide examples of connection details for the discontinuous LFRS of interest. Additionally, the prototype structure design served as a basis for the design of a full-scale two story shearwall test specimen. This specimen was built and had tests conducted on it in various 
configurations in the San Jose State Structures Laboratory as part of a 3-unit semester, graduate studies course civil engineering course (CE 269). The experimental work and results are detailed in a paper by McMullin titled "Experimental Evaluation of Discontinuous Timber Shear Walls" (2018).

\subsection{Conclusions}

Due to the current lack of full-scale woodframe-structure shake table experiments performed to analyze discontinuous LFRS, obtaining experimental data for such LFRS was difficult, if not impossible, for past experiments evaluated for the literature review. Despite this fact, careful evaluation of current building codes along with review of literature produced by industry personnel facilitated the design and detailing approach utilized in this document.

Design of discontinuous LFRS which utilizes ASD load combinations with overstrength imposes demand increases on components of the discontinuous LFRS when compared with the basic ASD load combinations. In the case of the prototype structure designed for this project, downward support reaction forces were increased by $32 \%$, uplift forces were increased by $128 \%$, and beam bending moment and shear force were increased by $56 \%$ and $44 \%$, respectively. These percentages are specific to the LFRS of this project, as site seismicity $\left(S_{D S}\right)$ varies in actual practice. 


\subsection{Recommendations for Engineering Practice}

Chapter 2, Section 1 of this report should serve as a point of reference for determining when to apply the overstrength factor to a discontinuous WSP LFRS. In addition, the detailing of connections of discontinuous WSP LFRS should ensure a load path is completed to the foundation level of the structure, such as shown in the structural details in Appendix A.

\subsection{Recommendations for Continuation of Research}

In order to best research the effects of in-plane offset vertical structural irregularities and out-of-plane offset horizontal structural irregularities on the seismic performance of a structure, full-scale shake table tests such as those reviewed for this report should be performed on structures designed to intentionally contain these types of irregularities. Testing structures containing these irregularities will facilitate the understanding of how such irregularities affect the performance of the structure locally (in the immediate vicinity of the discontinuity) and globally (of the structure as a whole). Furthermore, such experimentation would allow for more clarity as well as an empirical point of reference in building code treatments of irregular or discontinuous LFRS. Ideally, discontinuous LFRS experimentation on full-scale structures would include component level data acquisition for all elements of the discontinuous systems, to best address questions regarding structural elements which should or should not be designed with the overstrength factor $\left(\Omega_{0}\right)$. 


\section{References}

American Society of Civil Engineers. Minimum design loads and associated criteria for Buildings and Other Structures: ASCE7-10 2010.

California Building Standards Commission. (2017). 2016 California building code: California code of regulations, Title 24, Part 2(2016 ed.). Sacramento, CA: California Building Standards Commission.

(COR), I. C. (2011). International building code, 2012. Country Club Hills, IL: International Code Council.

NEHRP Recommended seismic provisions for new buildings and other structures(FEMA P-750). (2009). Washington, D.C.: U.S. Dept. of Homeland Security, Federal Emergency Management Agency, USGS.

Christovasilis, I. P., Filiatrault, A., \& Wanitkorkul, A. (2009). Seismic testing of a fullscale two-story light-frame wood building: NEESWood benchmark test (NEESWood, Tech. No. MCEER-09-0005). Buffalo, NY: MCEER.

Fischer, D., Filiatrault, A., Folz, B., Uang, C., \& Seible, F. (2001). Shake table tests of a two-story woodframe house(Rep. No. W-06). San Diego, CA: Department of Structural Engineering, UCSD.

Ghosh, S. (2014). Significant changes from ASCE 7-05 to ASCE 7-10, part 1: Seismic design provisions. PCI Journal,2014(Winter). Retrieved February 27, 2018, from http://skghoshassociates.com/sk_publication/PCI-Winter14 Seismic Design Precast Provisions in ASCE 7.pdf

Ghosh, S. (2014, May 15). Combining horizontal and vertical earthquake effects [Web log post]. Retrieved February 27, 2018, from https://skghoshassociates.com/SKGAblog/viewpost.php?id=18

Humar, J., \& Rahgozar, M. (1996). Concept of overstrength in seismic design(Eleventh World Conference on Earthquake Engineering, Tech. No. 639). Ottowa, Ontario: Carleton University.

McEntee, P. (2013, April 18). The omega factor [Web log post]. Retrieved February 27, 2018, from http://seblog.strongtie.com/2013/04/the-omega-factor/\#more-480

McMullin, K. M. (2016). Design of discontinuous systems for seismic resistance(Rep.). 
McMullin, K. M. (2018). Experimental evaluation of discontinuous timber shear walls(Rep.). Los Angeles, CA: Eleventh U.S. National Conference on Earthquake Engineering.

Nakamura, I., Shimizu, H., Minowa, C., Sakamoto, I., \& Suzuki, Y. (2008). E-Defense experiments on full scale wooden houses(Rep.). Beijing, China: 14th World Conference on Earthquake Engineering.

Nemetschek Company. (n.d.). RISA - Rapid Interactive Structural Analysis (Version 2D - 16.0.1) [Computer software].

Pei, S., Van de Lindt, J. W., Pryor, S. E., Shimizu, H., \& Rammer, D. R. (2010). Seismic testing of a full scale mid-rise building: The NEESWood Capstone Test (NEESWood, Tech. No. MCEER-10-0008). NEESWood.

Pouria Bahmani, John van de Lindt, Gary Mochizuki, Steve Pryor, Mikhail Gershfeld, jingjing tian, Michael Symans, Douglas Rammer (2014). 4-Story full-scale soft-story woodframe building test at UCSD, Network for Earthquake Engineering Simulation (distributor), Dataset, DOI:10.4231/D3F76678B 


\section{Appendices}

\section{Appendix A: Blueprints of Prototype Structure}

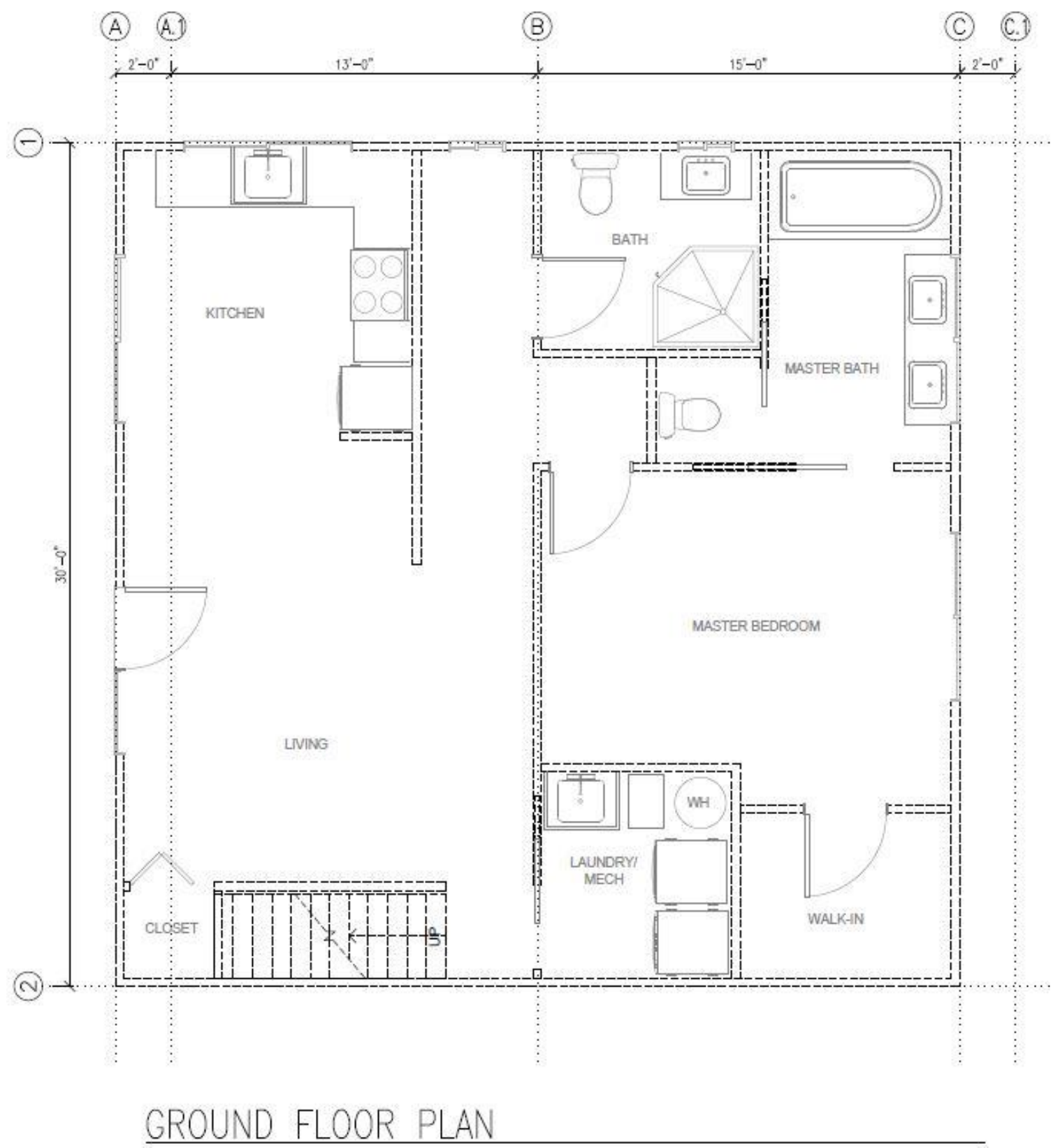

Figure A1. Architectural Ground Floor Plan 


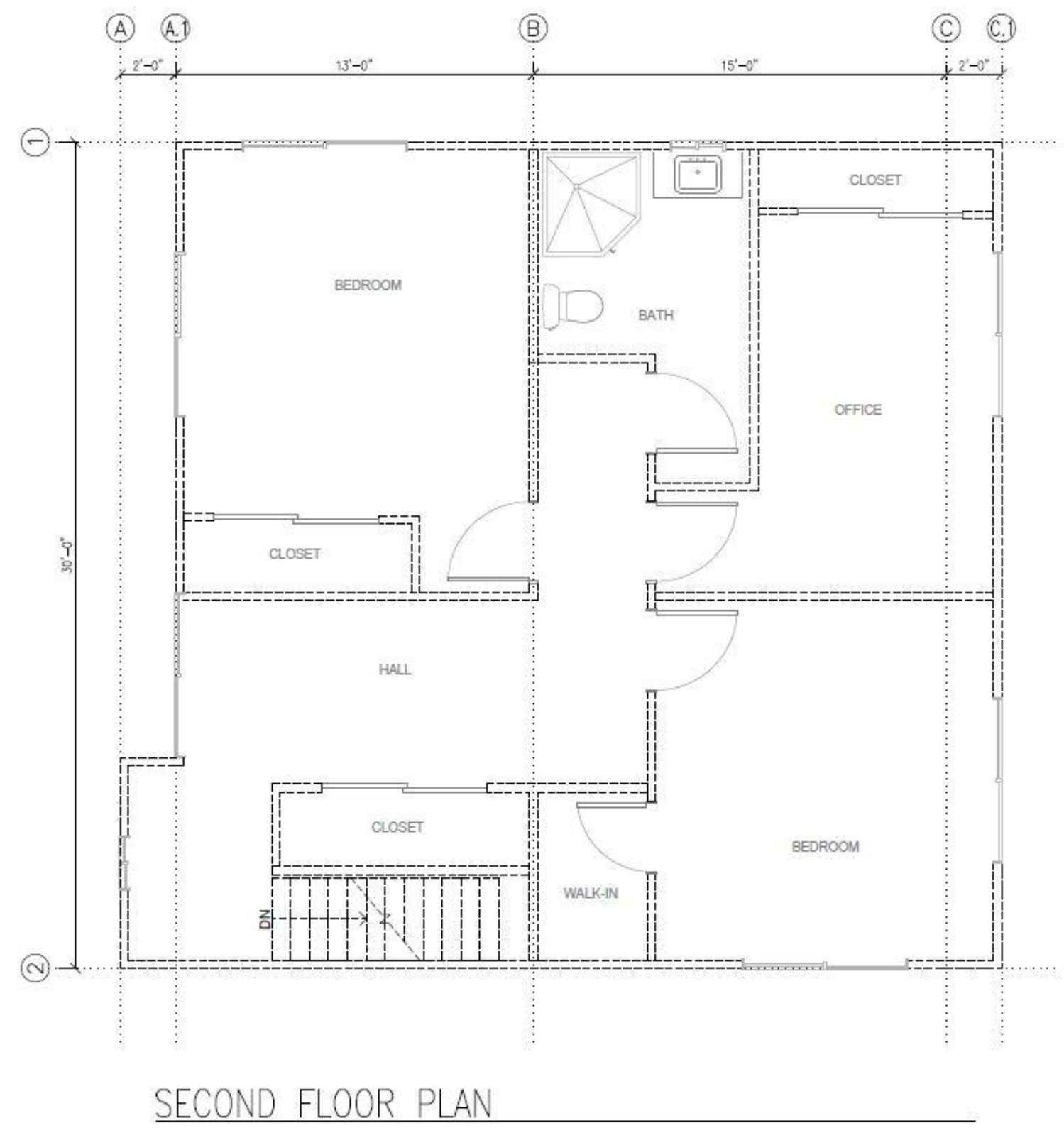

Figure A2. Architectural Second Floor Plan 
(A) (A.)

(B)

(C) (C.)

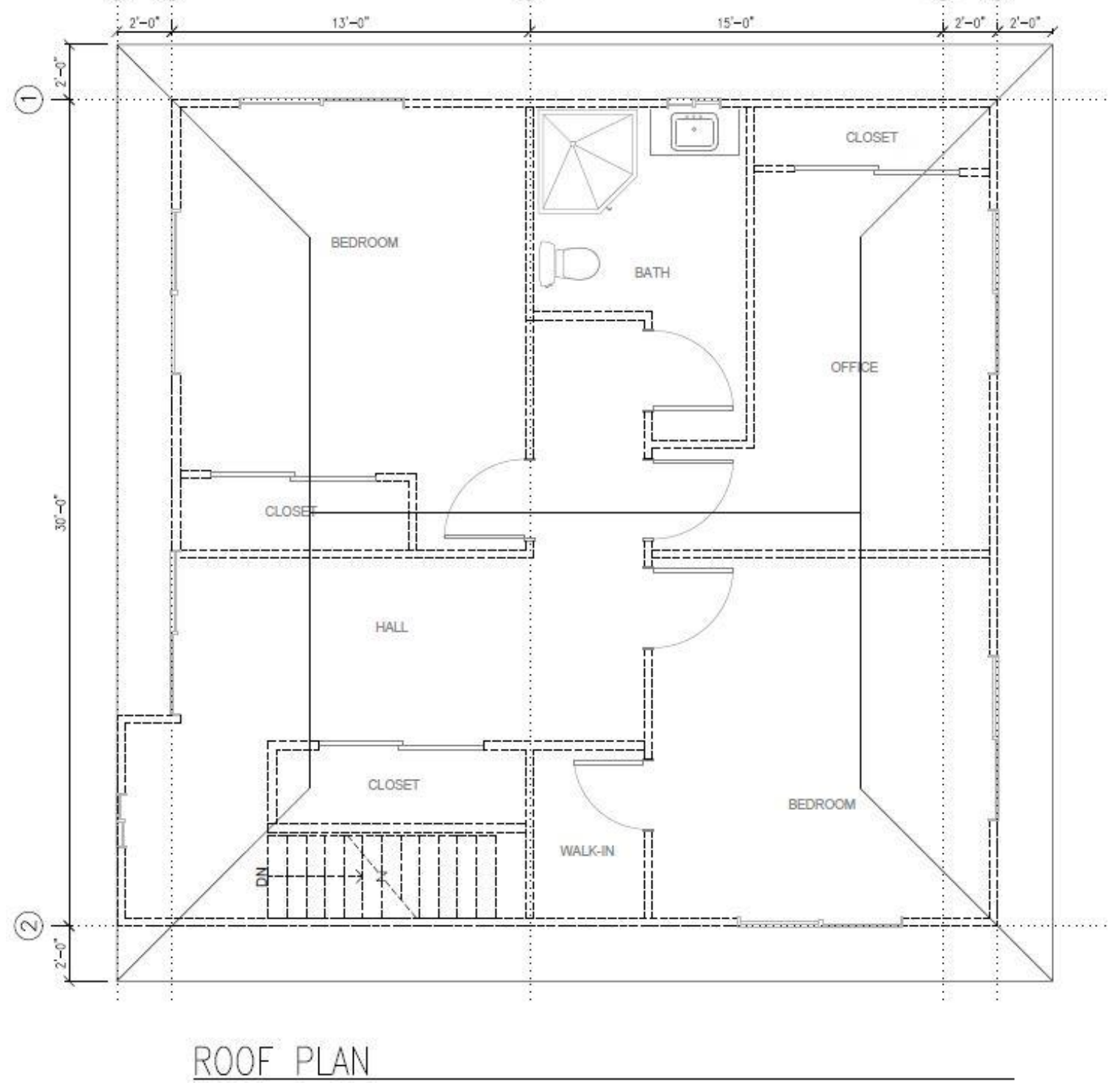

Figure A3. Architectural Roof Plan 


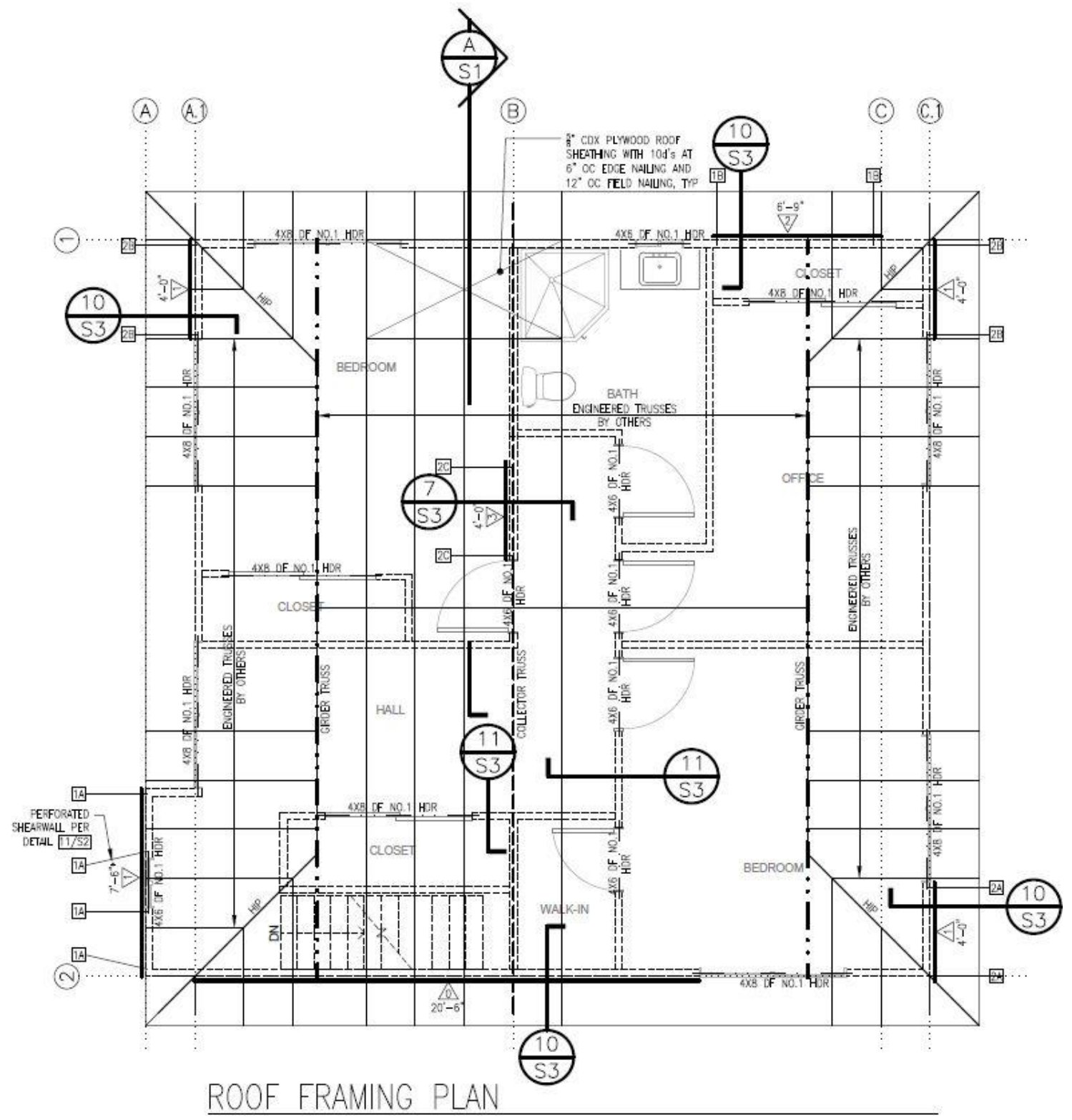

Figure A4. Roof Framing Plan 


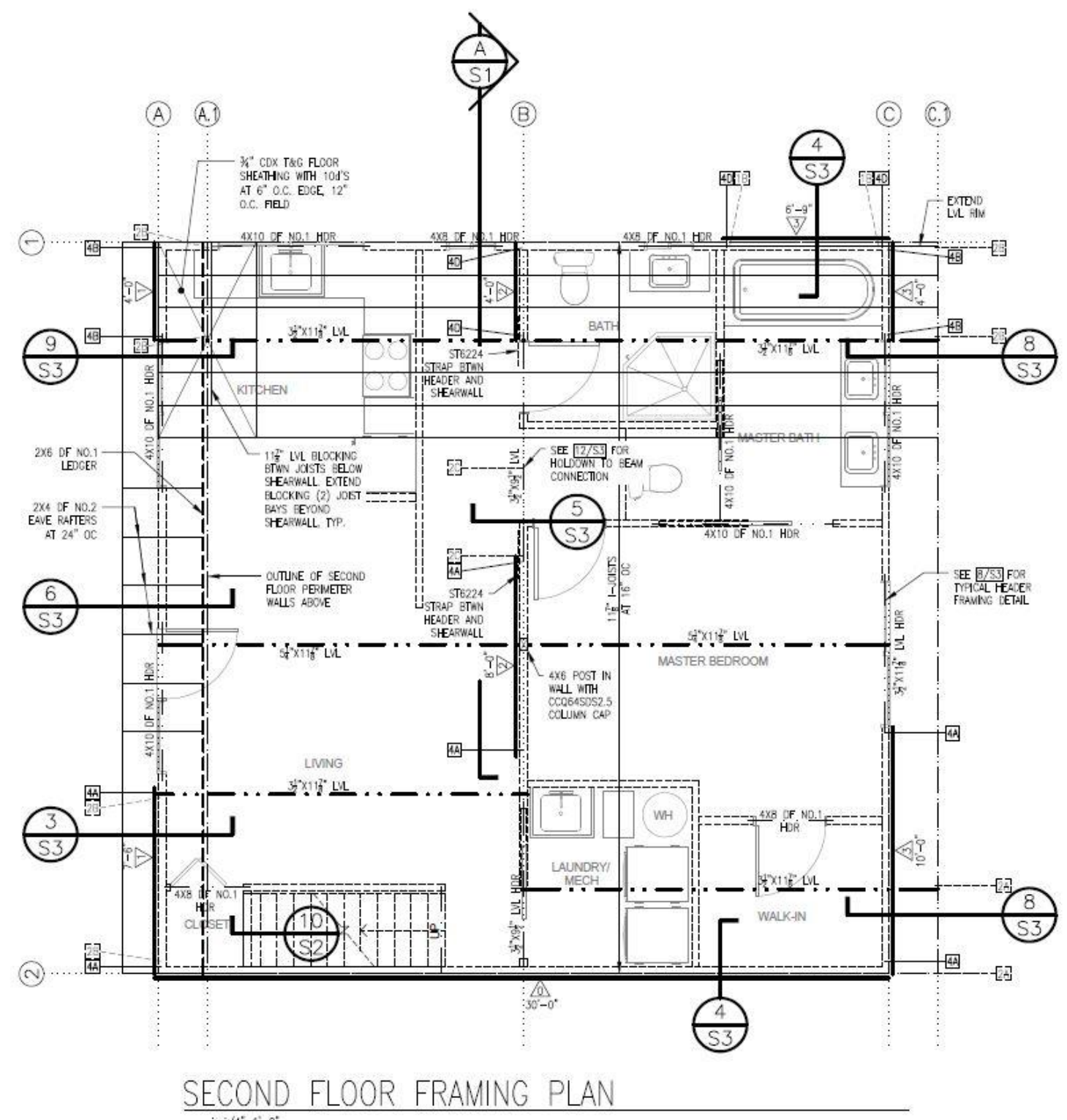

Figure A5. Second Floor Framing Plan 


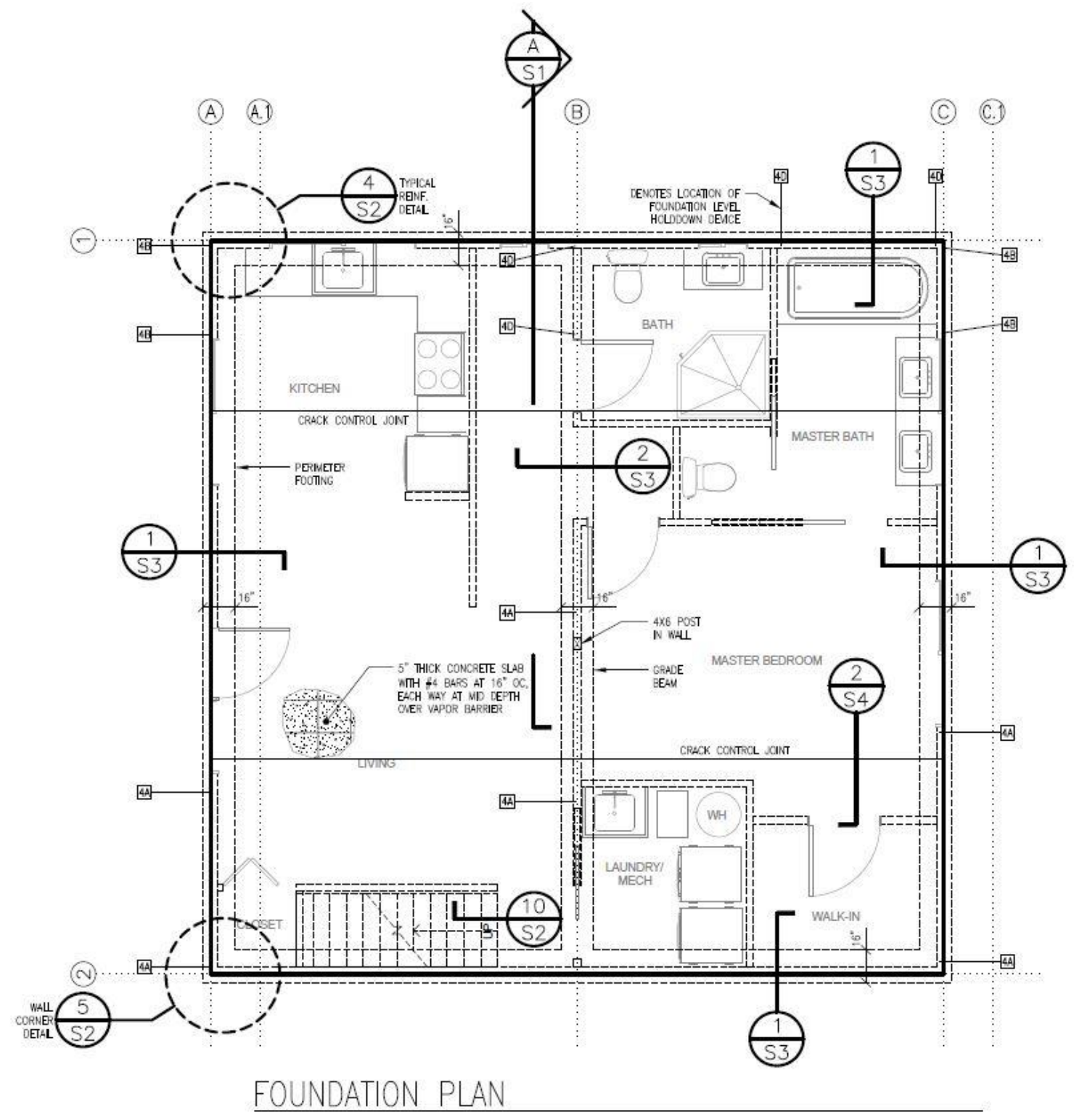

Figure A6. Foundation Plan 


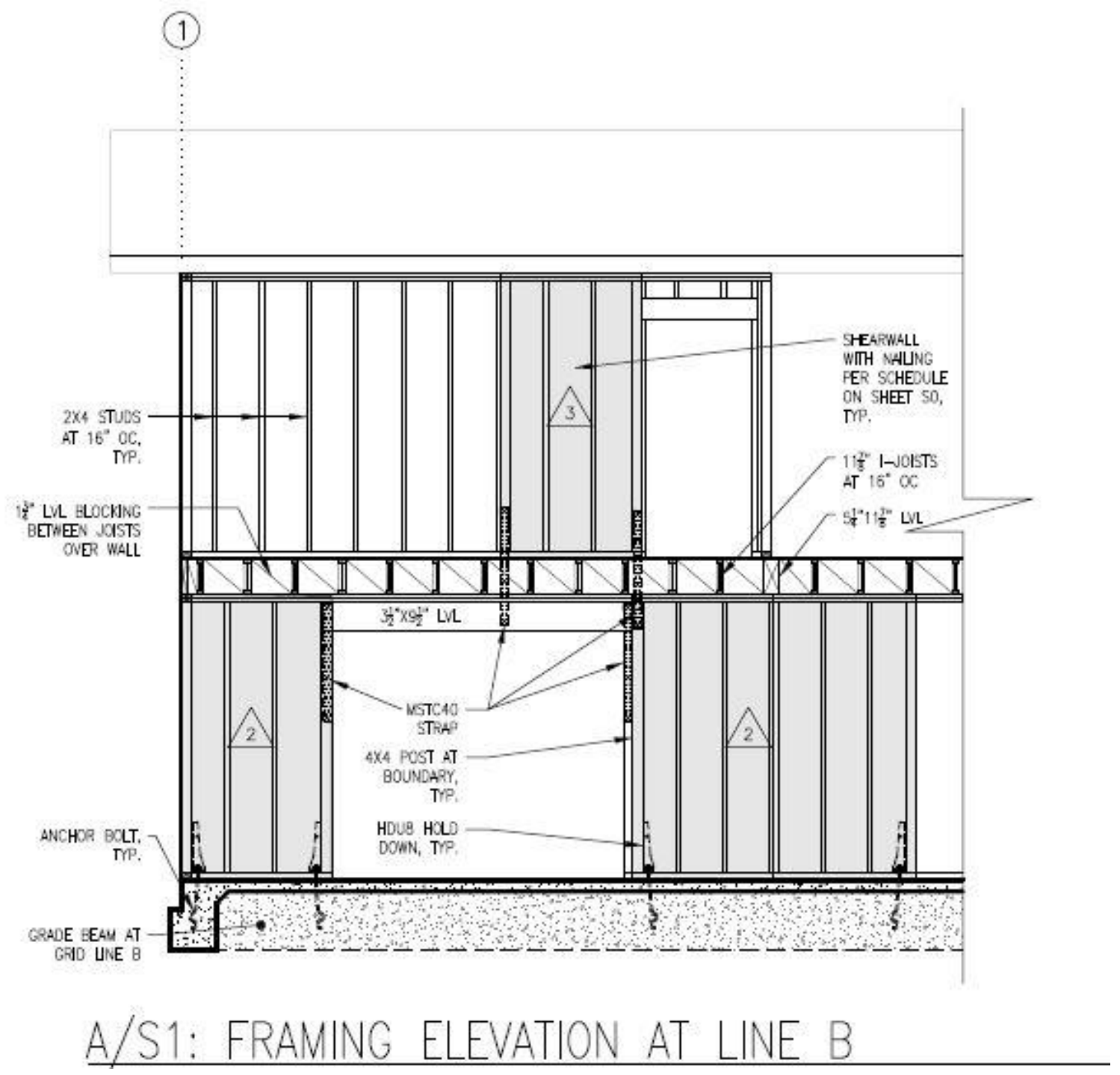

Figure A7. Framing Elevation at Grid Line B Type 4 Vertically Irregular LFRS 


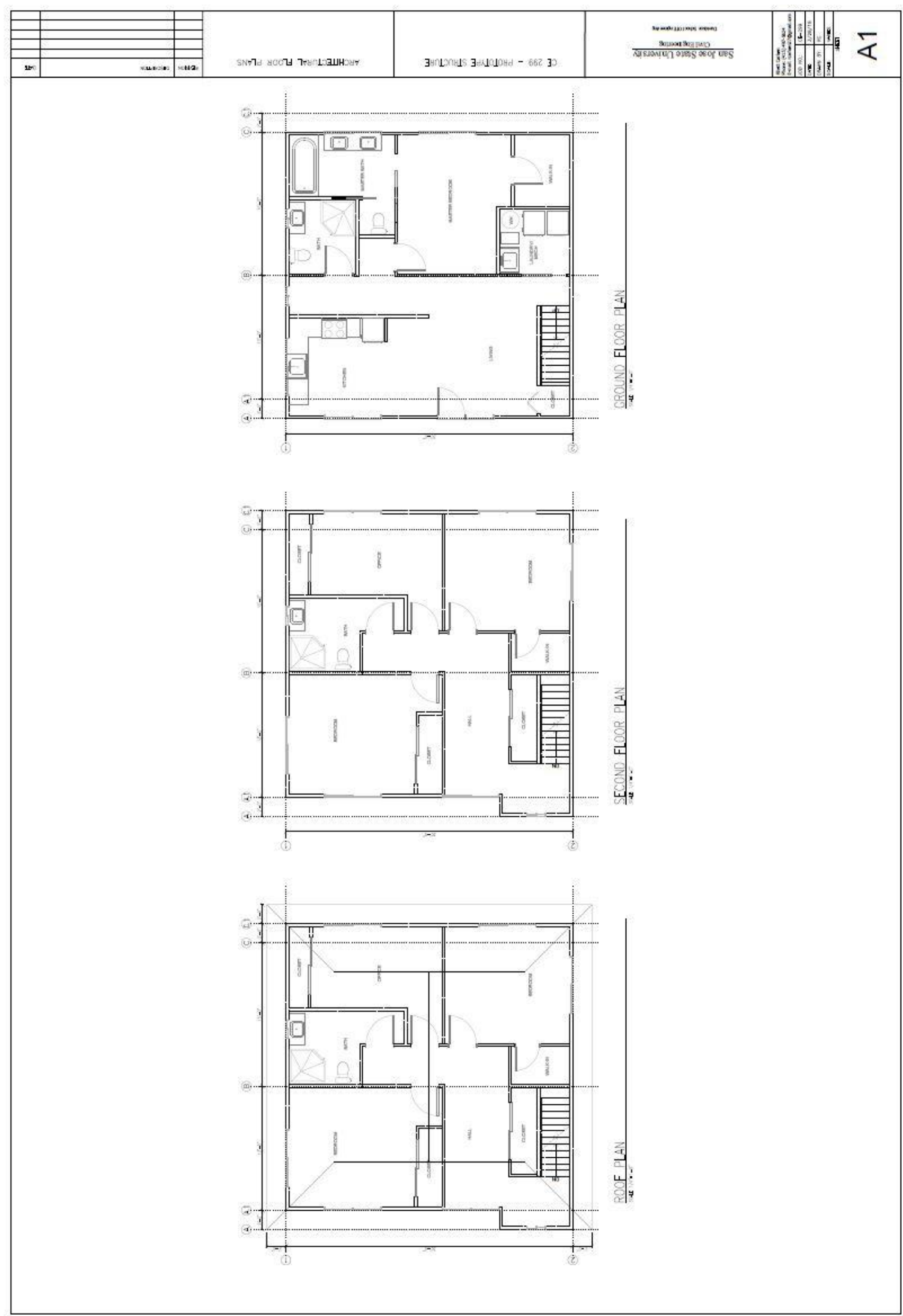




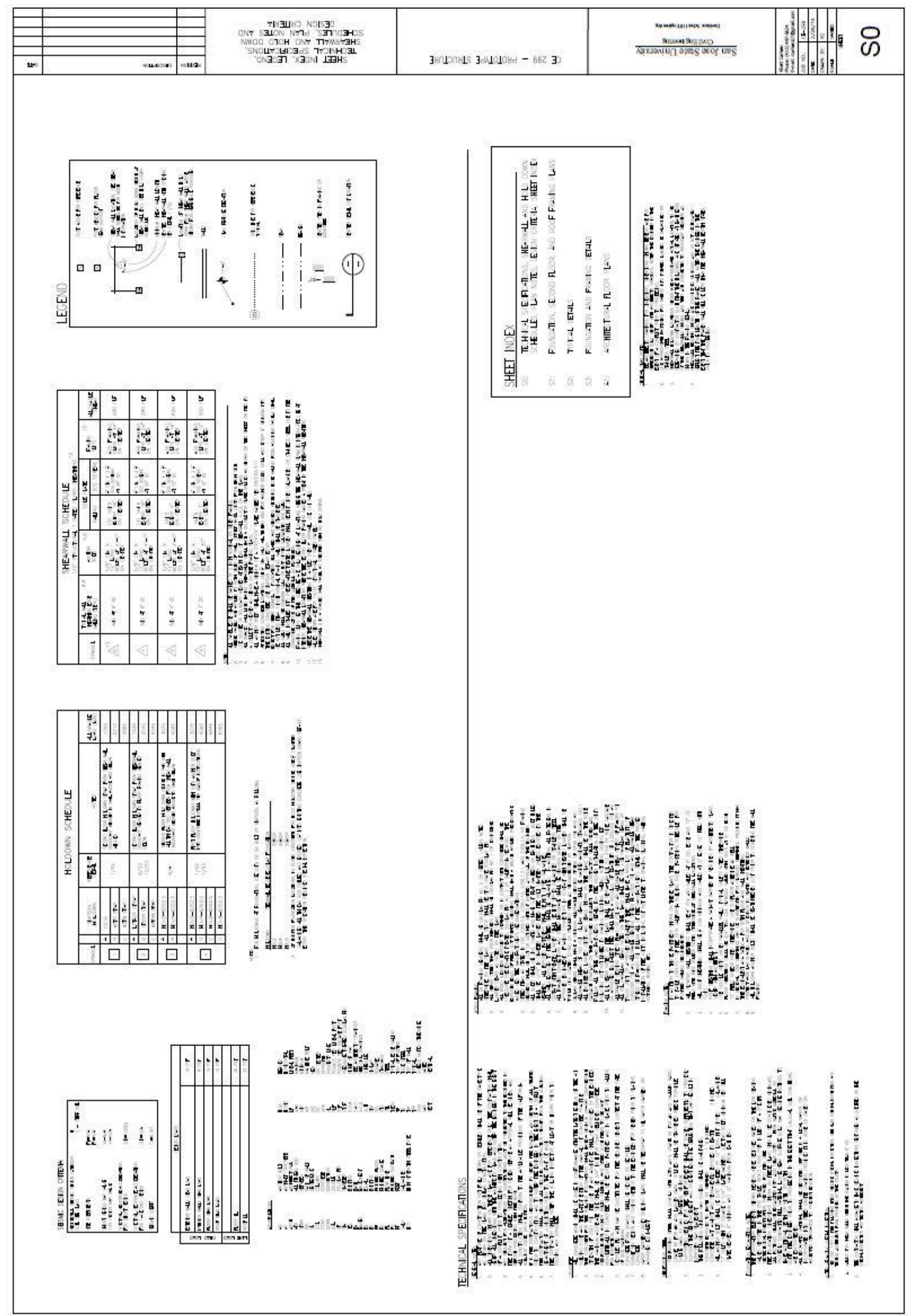




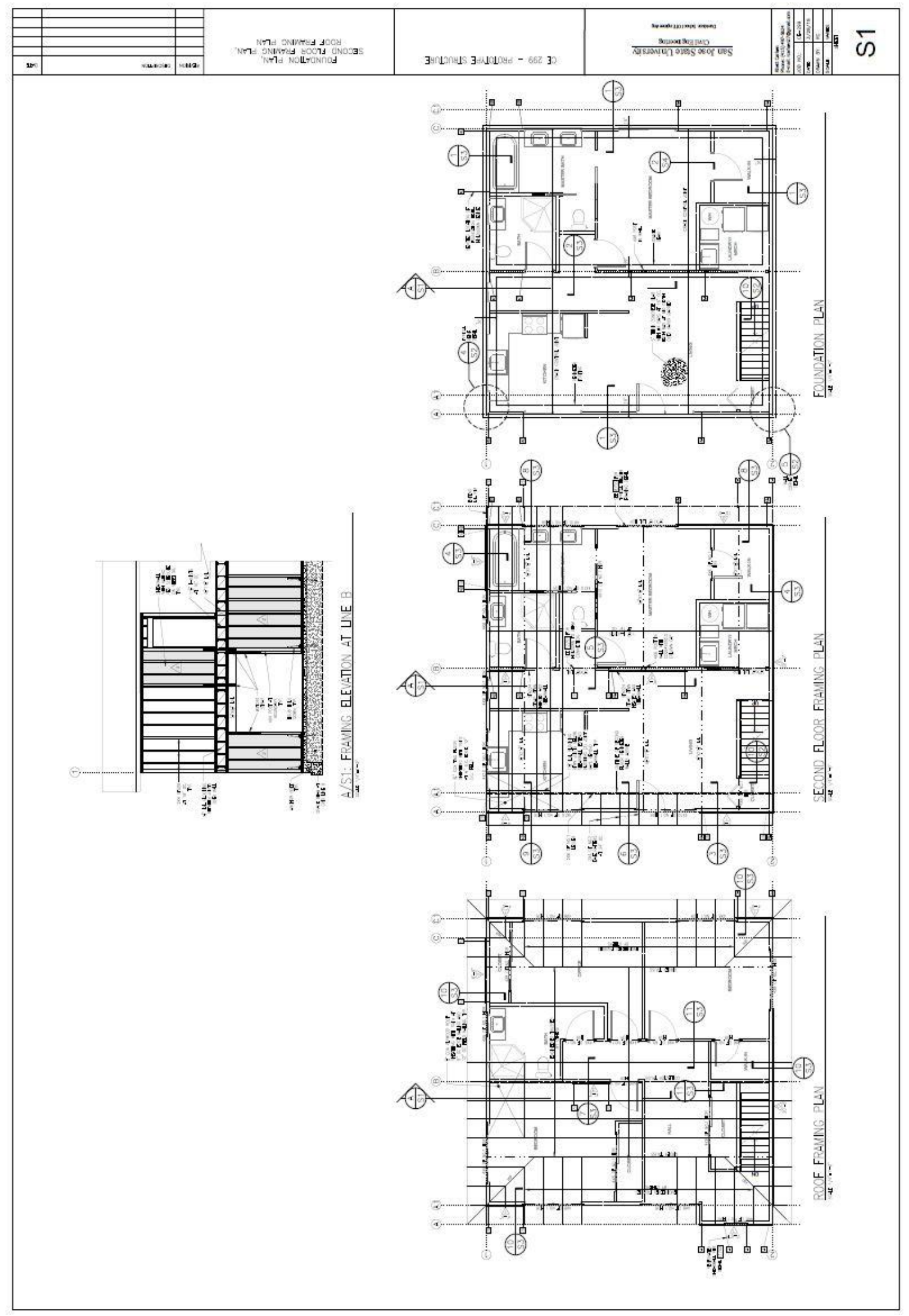




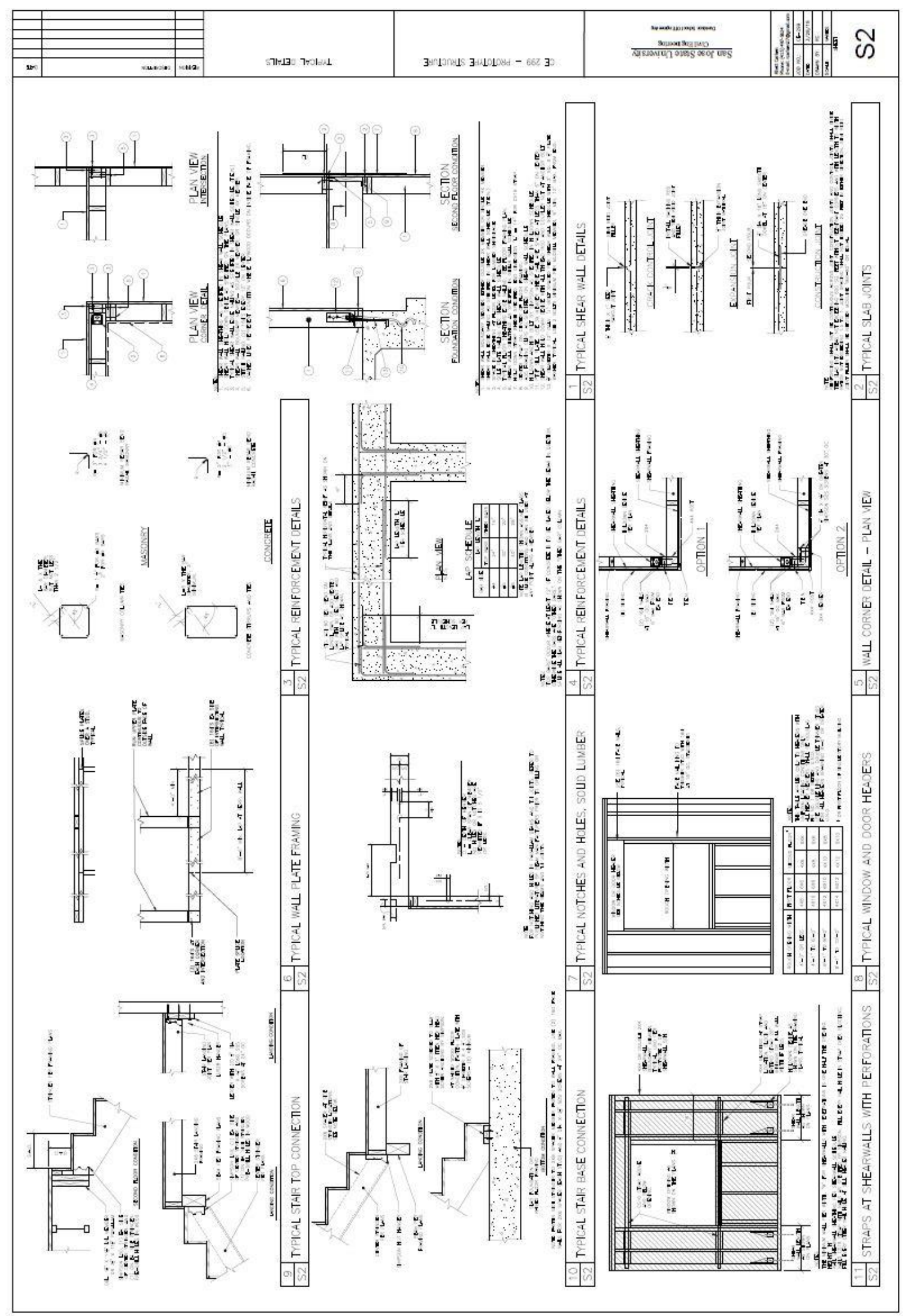




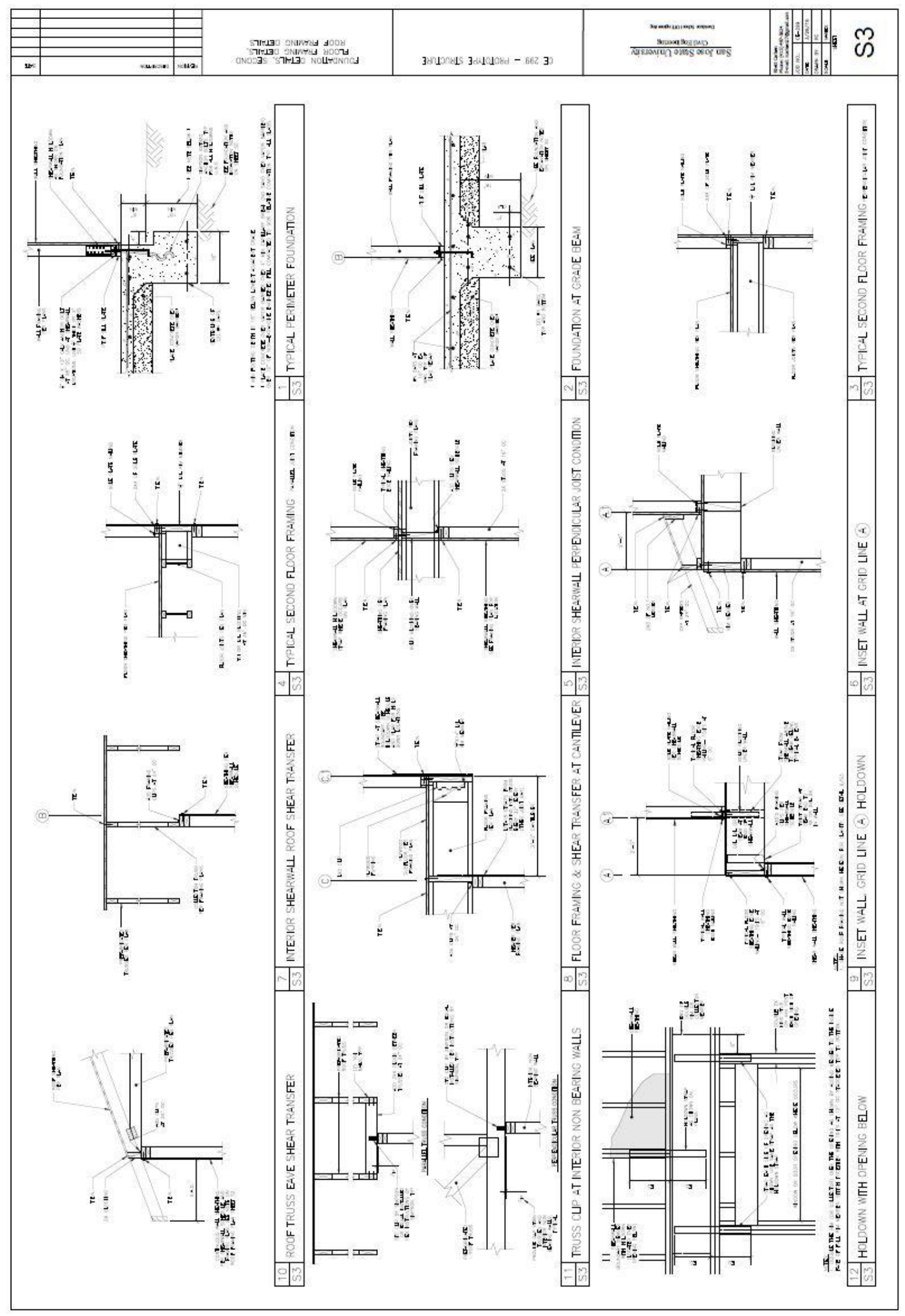




\section{Appendix B: Load Path Analysis of Prototype Structure}

DESIGN LOADS (PSF)

Dead Loads:

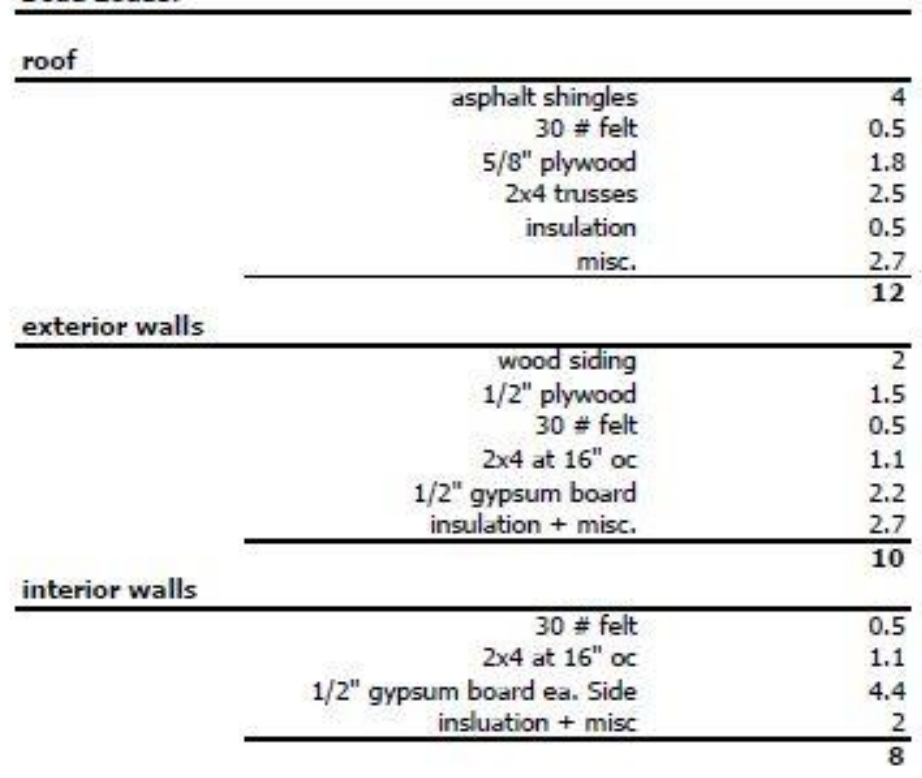

Floor
Prototype Structure Dead Weights $3 / 28 / 2018$

\begin{tabular}{rr} 
flooring & 4 \\
$3 / 4^{\prime \prime}$ plywood & 2.3 \\
TJ's at $16^{\prime \prime}$ oc & 2.7 \\
$5 / 8^{\prime \prime}$ gypsum board ceiling below & 2.75 \\
misc. & 2.25 \\
\hline
\end{tabular}

\begin{tabular}{lc} 
Live Loads: & \\
\hline Roof Live Loads & 20 \\
Floor Live Loads & 40 \\
Ceiling live Loads accessible ceiling spaces & 20 \\
Soil Bearing Pressure (CBC low value) & 1500
\end{tabular}

Figure B1. Design Loads for Concept/Prototype Structure 


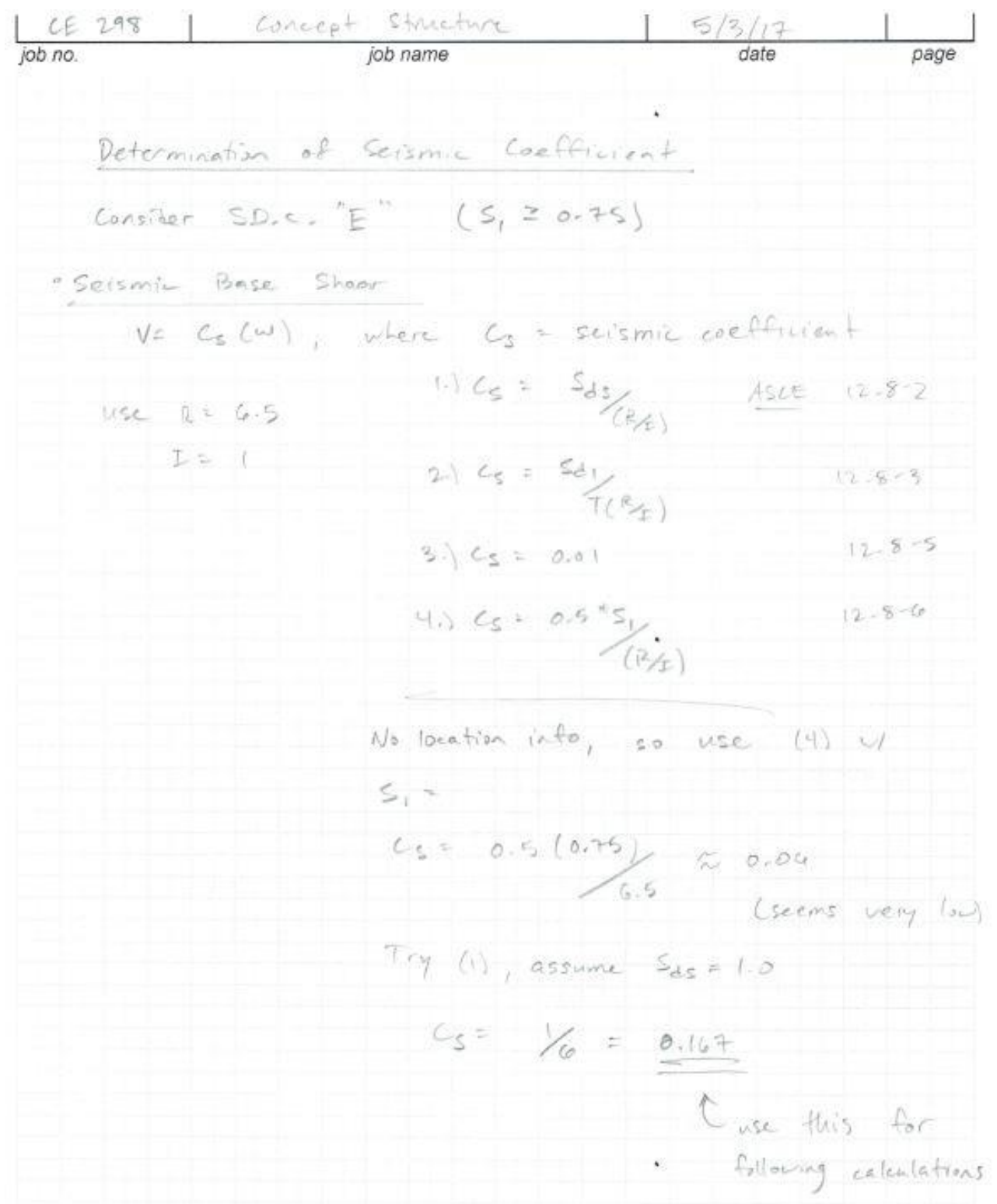

Figure B2: Determination of Seismic Coefficient, Cs 


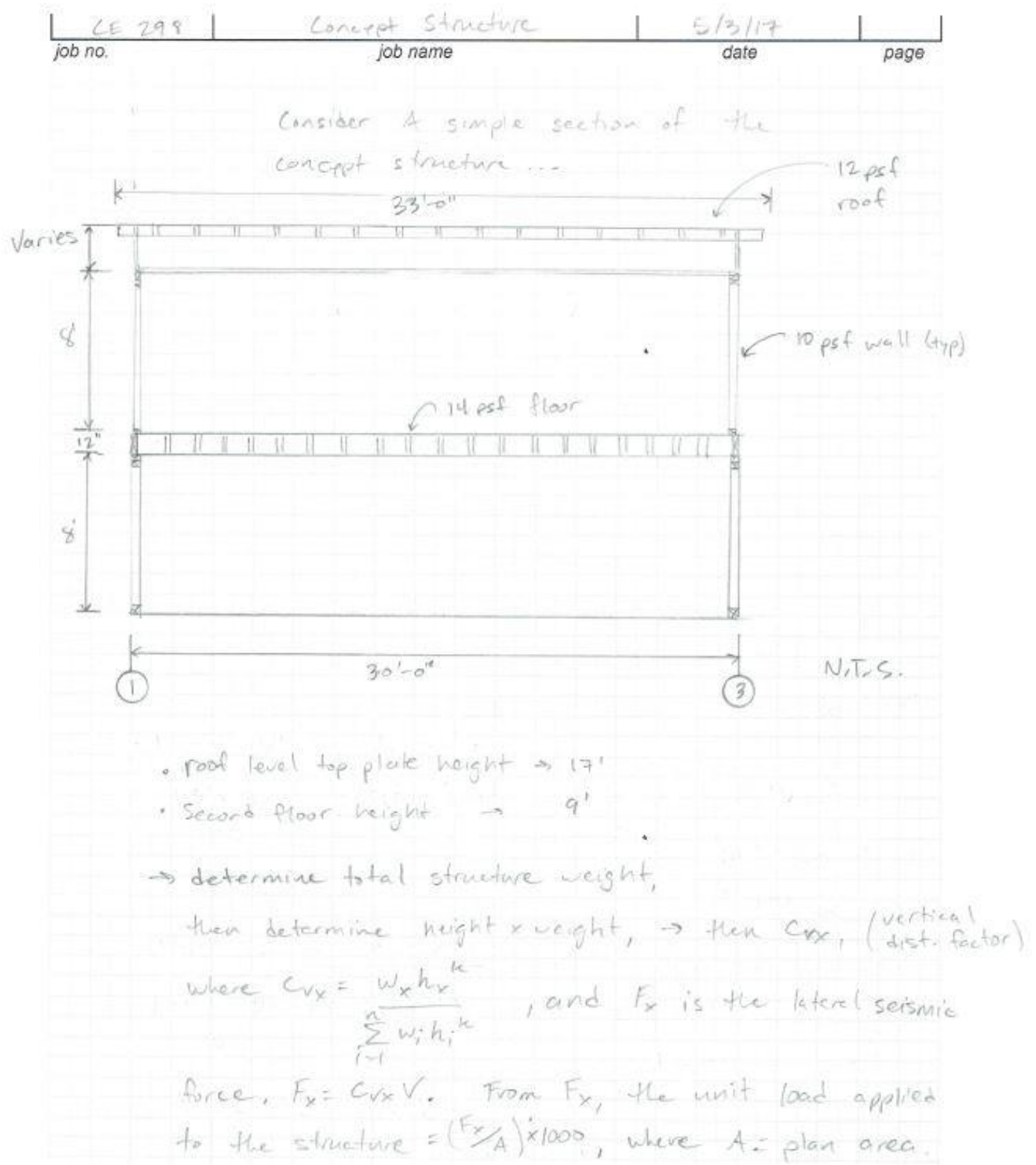

Figure B3: Lateral Analysis Height Distribution 


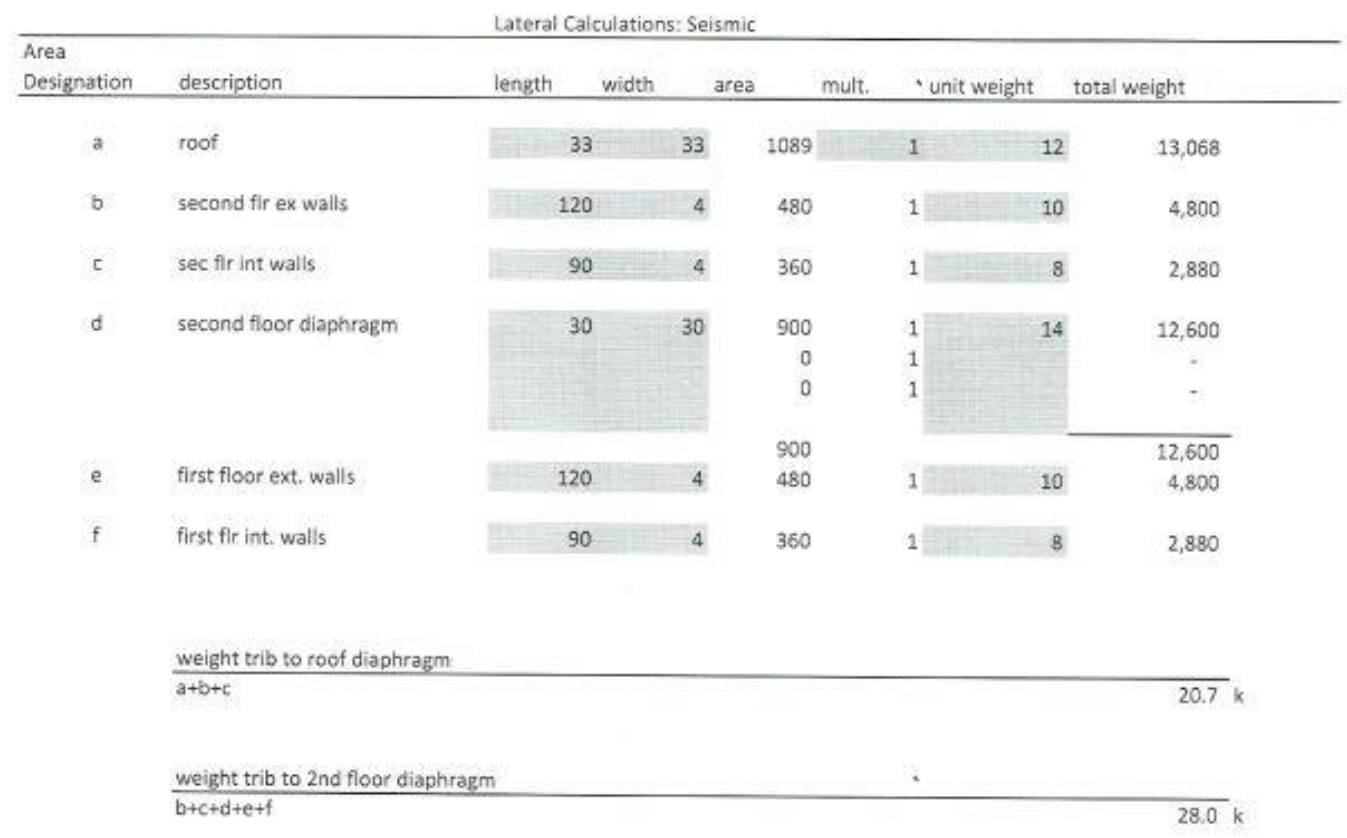

\begin{tabular}{|c|c|c|c|c|c|c|c|}
\hline level & weight (K) & ht & ht*w & $c v x$ & $\mathrm{Fx}$ & total plan area & unit load \\
\hline roof & 20.7 & 17 & 352.72 & 0.583623 & 4.75 & 1089 & 4.36 \\
\hline second flr & 28.0 & 9 & 251.64 & 0.416377 & 3.39 & 900 & 3.76 \\
\hline totals & 48.71 & & 604.36 & & & & \\
\hline base shear V & 8.13 & & & & & & \\
\hline seismic coeff. = & 0.17 & attachec & sheet & & & & \\
\hline
\end{tabular}

Figure B4: Determination of Seismic Weight as prescribed by

ASCE 7-05/10 Section 12.8.3 

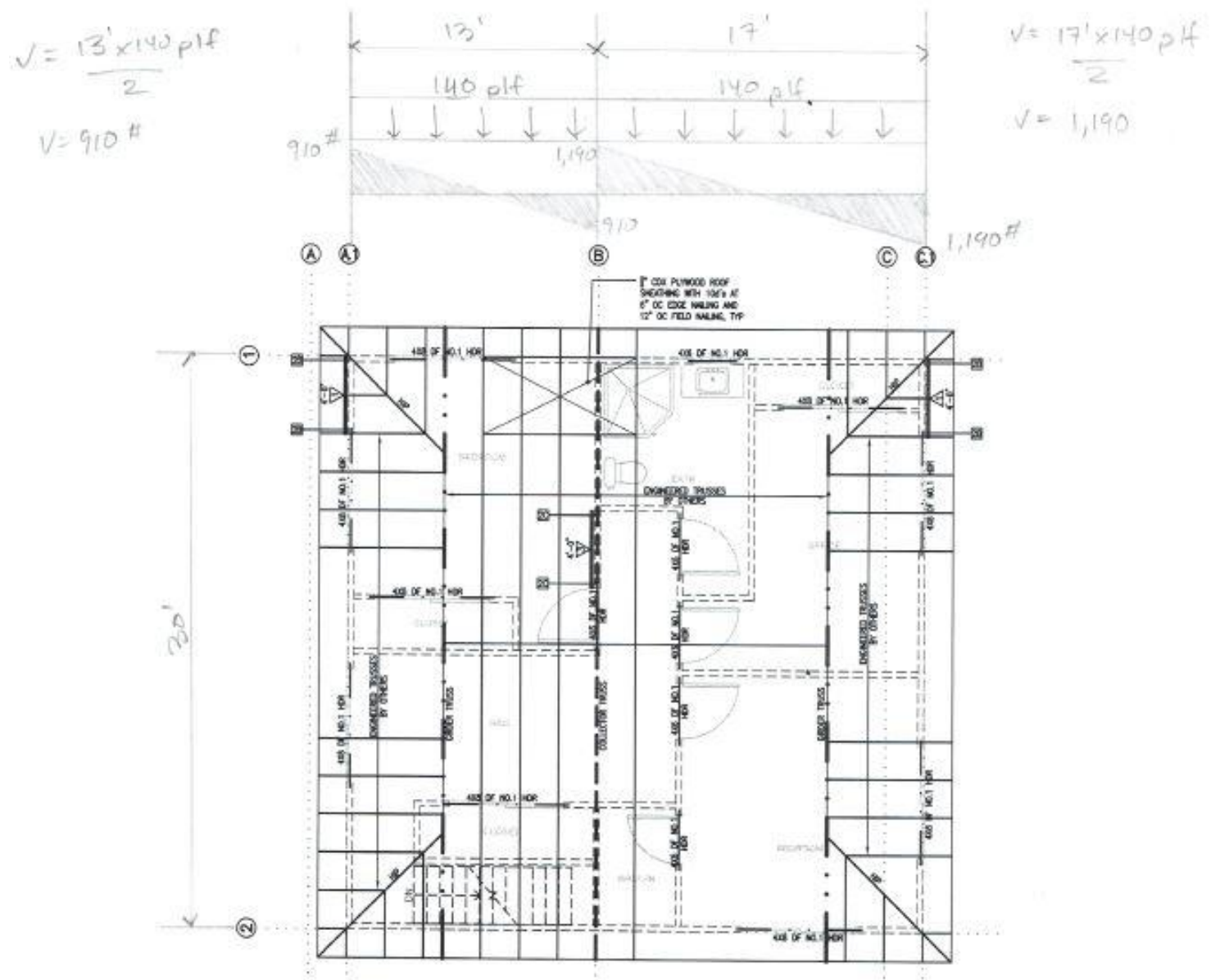

ROOF FRAMING PLAN

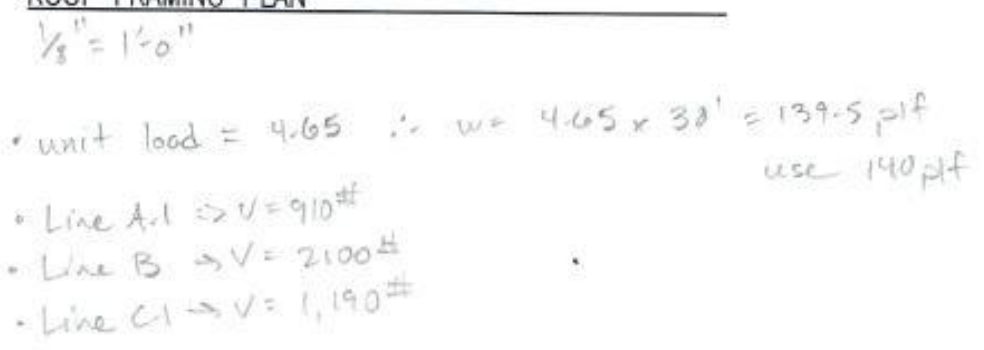

Figure B5: Roof Level Shear Force Diagram 

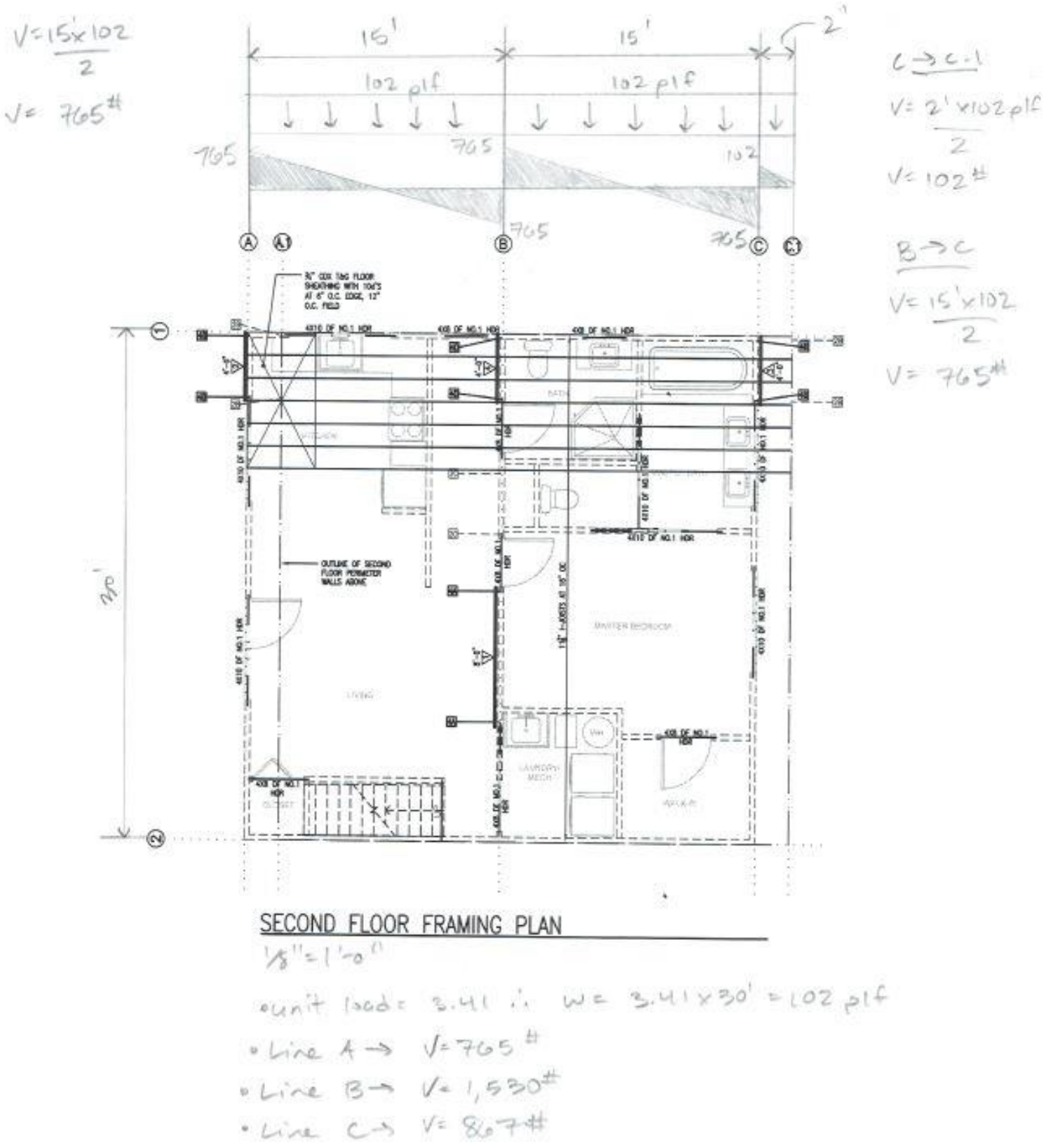

$V=\frac{15^{\prime} \times 102}{2}$ $V=765^{\text {th }}$

Figure B6: Second Floor Shear Force Diagram 


\begin{tabular}{|c|c|c|c|c|c|c|c|c|c|c|c|c|c|c|}
\hline & \multirow{3}{*}{ 免 } & \multicolumn{5}{|c|}{ shearwall length ( $\mathrm{ft}$ ) } & \multirow{3}{*}{$\begin{array}{c}\text { shear } \\
\text { plf }\end{array}$} & \multirow{3}{*}{ 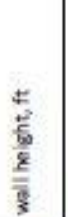 } & \multirow{3}{*}{ 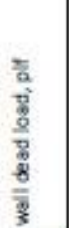 } & \multirow{3}{*}{ 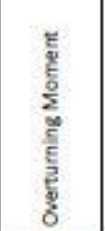 } & \multirow{3}{*}{ 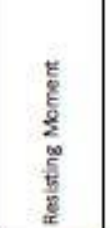 } & \multirow{3}{*}{$\begin{array}{l}\frac{y}{2} \\
\frac{8}{2} \\
\frac{5}{2}\end{array}$} & \multirow{3}{*}{$\begin{array}{l}\text { ठ } \\
\text { है } \\
\text { है } \\
\text { है } \\
\text { है }\end{array}$} & \multirow{3}{*}{$\begin{array}{l}7 \\
\frac{8}{5} \\
\frac{5}{0} \\
5 \\
\frac{5}{8} \\
0 \\
\frac{10}{8}\end{array}$} \\
\hline & & \multicolumn{3}{|c|}{ individual walls: } & \multirow{2}{*}{$\begin{array}{l}\text { total } \\
\text { length }\end{array}$} & \multirow{2}{*}{$\begin{array}{c}\text { force } \\
\text { lbs }\end{array}$} & & & & & & & & \\
\hline & & 1 & 2 & $\begin{array}{lll}3 & 4 & 5 \\
\end{array}$ & & & & & & & & & & \\
\hline u & A. 1 & 4.007 & 7.50 & & 11.5 & 910 & 79 & 8 & 100 & 2532.174 & 500 & 433 & 1 & $2 A, 1 A$ \\
\hline L & $A$ & 4.07 & 7.50 & & 11.50 & 765 & 146 & 8 & 145 & 4660.87 & 1160 & 875 & & $\angle B$ \\
\hline & & & & & & & & & & & & 1,308 & & \\
\hline u & B & 4.00 & & & 4 & 2100 & 525 & 8) & 100 & 16500 & 800 & 4,000 & 3 & $2 \mathrm{C}$ \\
\hline L & B & $4.00=$ & 8.00 & & 12.00 & 1530 & 303 & 8 & 145 & 9680 & 1160 & 2,130 & 2 & 4D \\
\hline & & & & & & & & & & & & 6,130 & & \\
\hline u & C.1 & 4.00 & 4.00 & & 8 & 1190 & 149 & 8 & 100 & 4760 & 800 & 990 & 2 & 24 \\
\hline L & c & $4.00 \quad 10$ & 10.00 & & 14.00 & 867 & 147 & 8 & 145 & 4701.714 & 1160 & 885 & 3 & 44 \\
\hline & & & & & & & & & & & & 1,875 & & \\
\hline u & 1 & 6.75 & & & 6.75 & 2100 & 311 & 8 & 100 & 16500 & 2278.125 & 2,151 & 2 & $1 \mathrm{~B}$ \\
\hline L & & 6.75 & & & 6.75 & 1530 & 538 & 8 & 145 & 29040 & 3303.281 & 3,813 & 3 & $\angle D$ \\
\hline & & & & & & & & & & & & 5,964 & & \\
\hline u & 2 & 20.50 & & & 20.5 & 2100 & 102 & 8 & 100 & 16800 & 21012.5 & 0 & 0 & N/A \\
\hline L & & 30.00 & & & 30.00 & 1530 & 121 & 8 & 145 & 29040 & 65250 & 0 & 0 & N/A \\
\hline & & & & & & & & & & & & & & \\
\hline & & & & & & & & & & & & & & \\
\hline
\end{tabular}

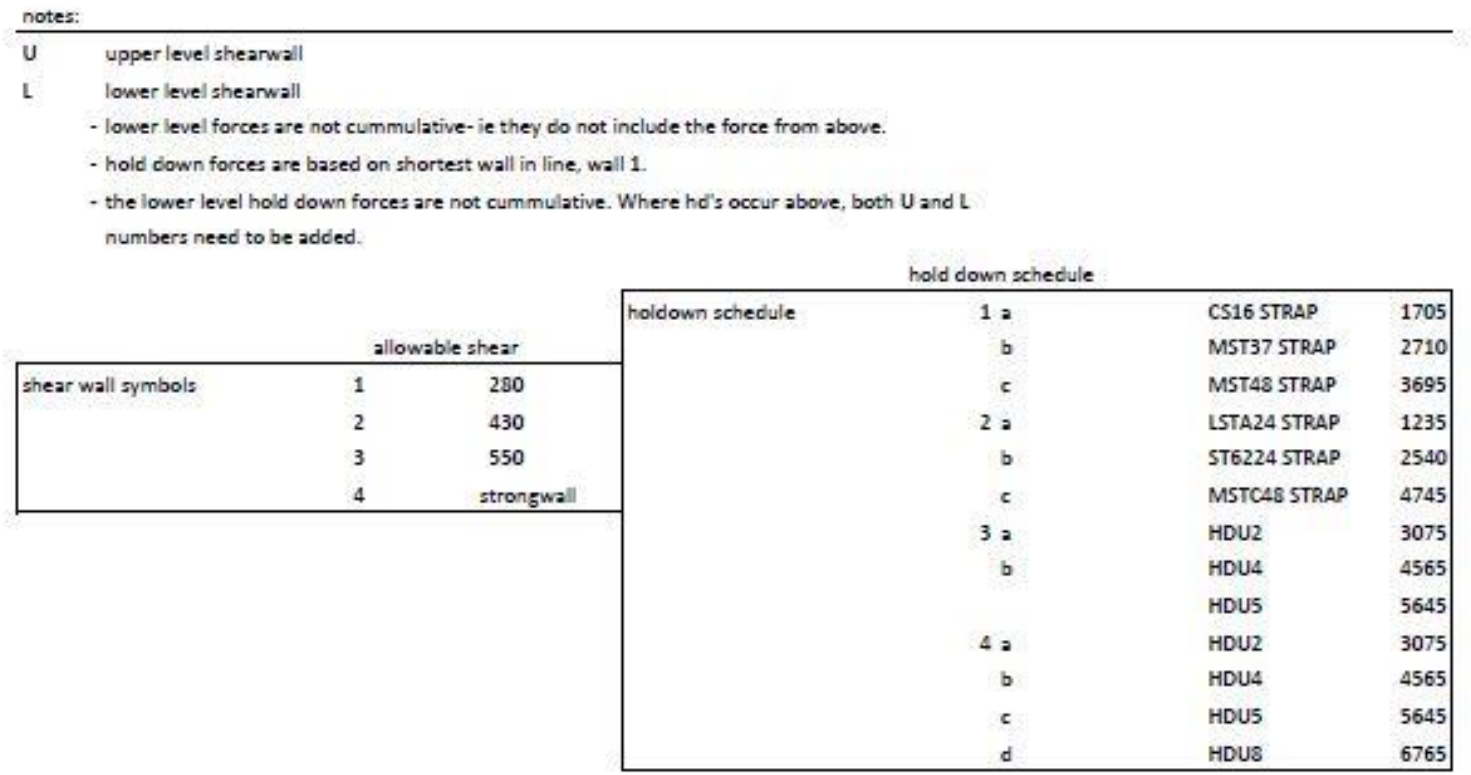

Figure B7: Shearwall lengths and forces 

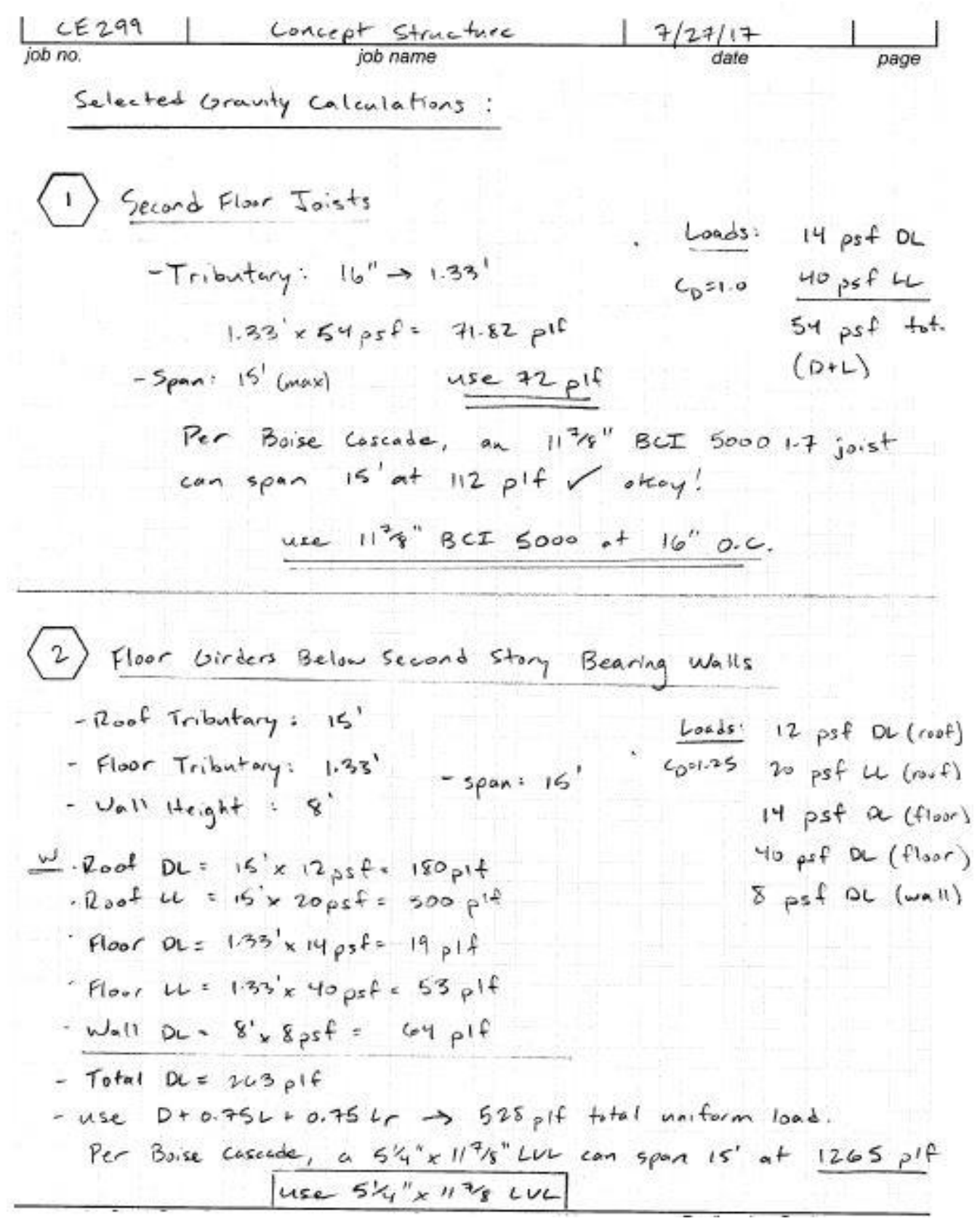

Figure B8. Selected Gravity Calculations for Prototype Structure 


\section{Appendix C: RISA Software Analysis Results for Prototype Structure In-Plane Type 4 Vertically Irregular LFRS}

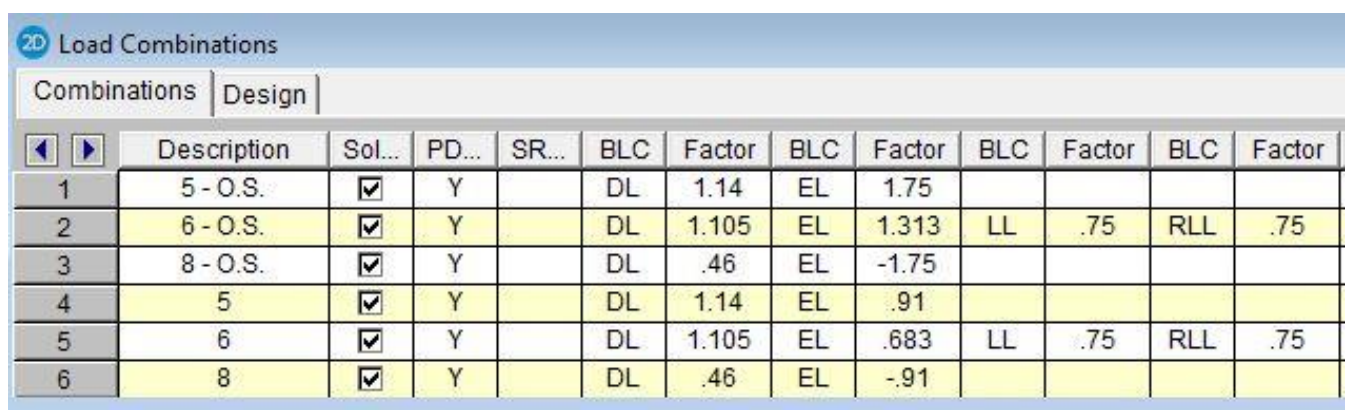

Figure C1. Load Combinations used for RISA Software Analysis

Notes regarding load combinations of Figure C1:

Beginning with the ASD load combination with overstrength factor,

5. $\left(1.0+0.14 S_{D S}\right) D+H+F+0.7 \Omega_{o} Q_{E}$

We apply the value of $S_{D S}$ (in this case, 1 ) and $\Omega_{o}(2.5)$. We have not considered $H$ or $F$ loads in this analysis. The resulting load combination becomes,

$1.14 D+1.75 Q_{E}$

The same process applies to load combinations 6 and 8 , with $S_{D S}=1$ and $\Omega_{o}=2.5$.

6. $\left(1.0+0.105 S_{D S}\right) D+H+F+0.525 \Omega_{o} Q_{E}+0.75 L+0.75\left(L_{r}\right.$ or $S$ or $\left.R\right)$ becomes

$1.105 D+1.313 Q_{E}+0.75 L+0.75 L_{r}$, and

8. $\left(0.6-0.14 S_{D S}\right) D+0.7 \Omega_{o} Q_{E}+H$ becomes

$0.46 D-1.75 Q_{E}$

We note that $Q_{E}$ is now subtracted, to indicate that the earthquake loading is counteracting the dead loads. 


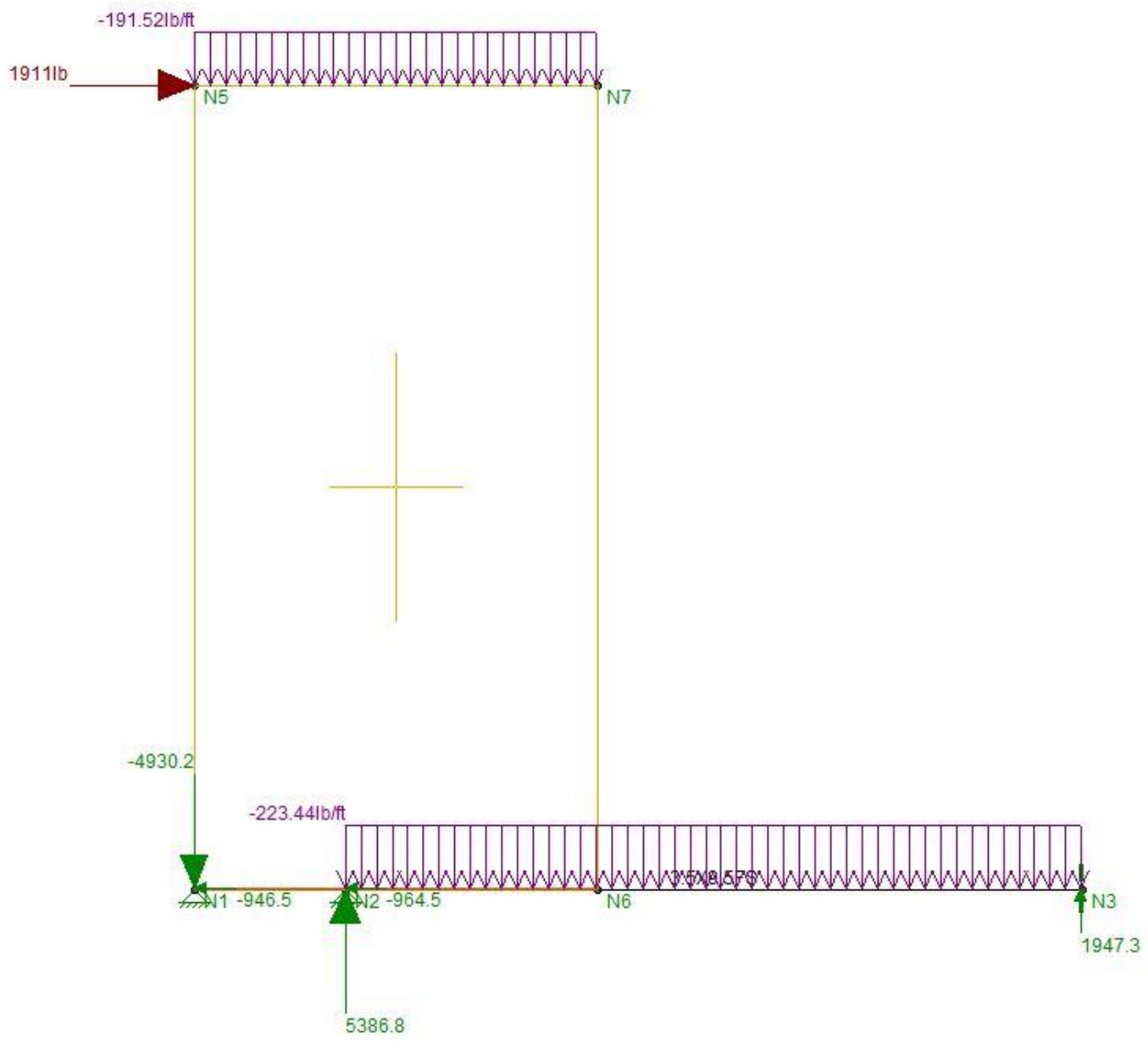

Figure C2. RISA Model Diagram - ASD Basic Load Combination 5 


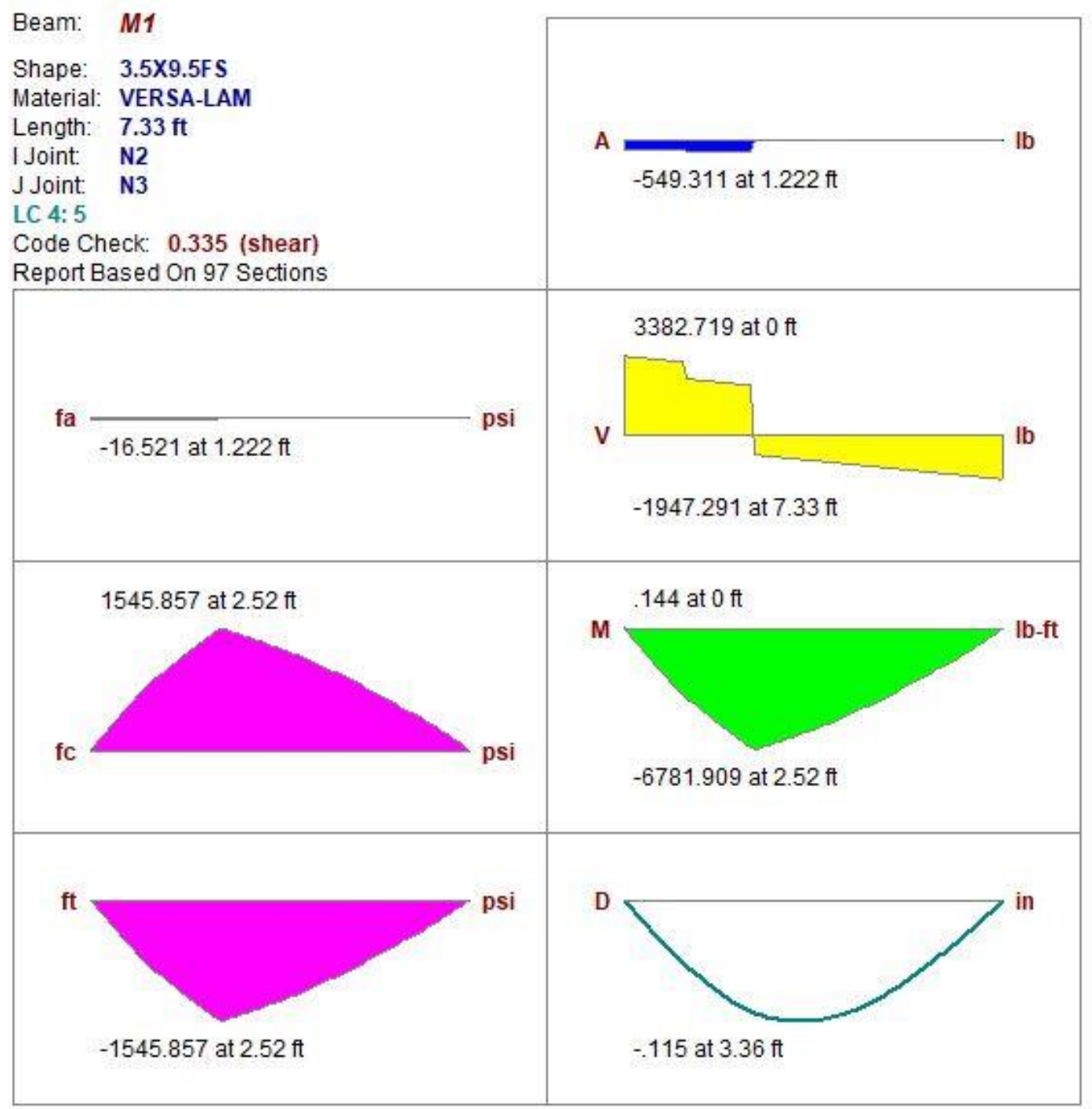

AF\&PA NDS-05/08: ASD Code Check

\begin{tabular}{|c|c|c|c|c|c|c|c|}
\hline \multirow{3}{*}{\multicolumn{2}{|c|}{$\begin{array}{l}\text { Max Bending Checl } \\
\text { Location } \\
\text { Equation }\end{array}$}} & \multicolumn{2}{|c|}{0.317} & \multicolumn{4}{|c|}{ Max Shear Check 0.335} \\
\hline & & \multirow{2}{*}{\multicolumn{2}{|c|}{$\begin{array}{l}2.52 \pi \\
3.9-3\end{array}$}} & \multicolumn{2}{|c|}{ Location } & \multicolumn{2}{|l|}{$0 \mathrm{ft}$} \\
\hline & & & & \multicolumn{2}{|c|}{ Max Defl Ratio } & L/765 & \\
\hline \multirow{3}{*}{$\begin{array}{l}\mathrm{CD} 1 \\
\mathrm{Cr}\end{array}$} & \multirow{2}{*}{\multicolumn{2}{|c|}{$\begin{array}{l}\text { RB } 8.259 \\
\text { Cfu } 1\end{array}$}} & & $\mathrm{CL} .983$ & \multirow[t]{2}{*}{$\mathrm{CV}$} & \multirow[t]{2}{*}{1} & \multirow{6}{*}{$\begin{array}{l}\text { In } \\
7.33 \mathrm{ft} \\
9.259 \\
\text { No }\end{array}$} \\
\hline & & & & CP .276 & & & \\
\hline & (psi) & $\mathrm{Cm}$ & $\mathrm{Ct}$ & $\mathrm{CF}$ & \multirow{4}{*}{$\begin{array}{l}\mathrm{Lb} \\
\text { le/d } \\
\text { Sway }\end{array}$} & \multirow{4}{*}{$\begin{array}{l}\text { Out } \\
7.33 \mathrm{ft} \\
25.131 \\
\text { No }\end{array}$} & \\
\hline $\mathrm{Fc}^{\prime}$ & 1325.08 & 1 & 1 & 1 & & & \\
\hline $\mathrm{Ft}^{\mathrm{t}}$ & 3440 & 1 & 1 & 1 & & & \\
\hline $\mathrm{Fb}^{\prime}$ & 4873.447 & 1 & 1 & 1 & & & \\
\hline $\mathrm{Fv}^{\prime}$ & \begin{tabular}{|l|}
456 \\
\end{tabular} & 1 & 1 & & \multirow{2}{*}{\multicolumn{2}{|c|}{$\begin{array}{l}\text { Le-Bending Top } \\
\text { Le-Bending Bot }\end{array}$}} & \\
\hline $\mathrm{E}^{\prime}$ & $2 e+6$ & 1 & 1 & & & & $33 \mathrm{ft}$ \\
\hline
\end{tabular}

Figure C3. RISA Software Analysis Results - ASD Basic Load Combination 5 


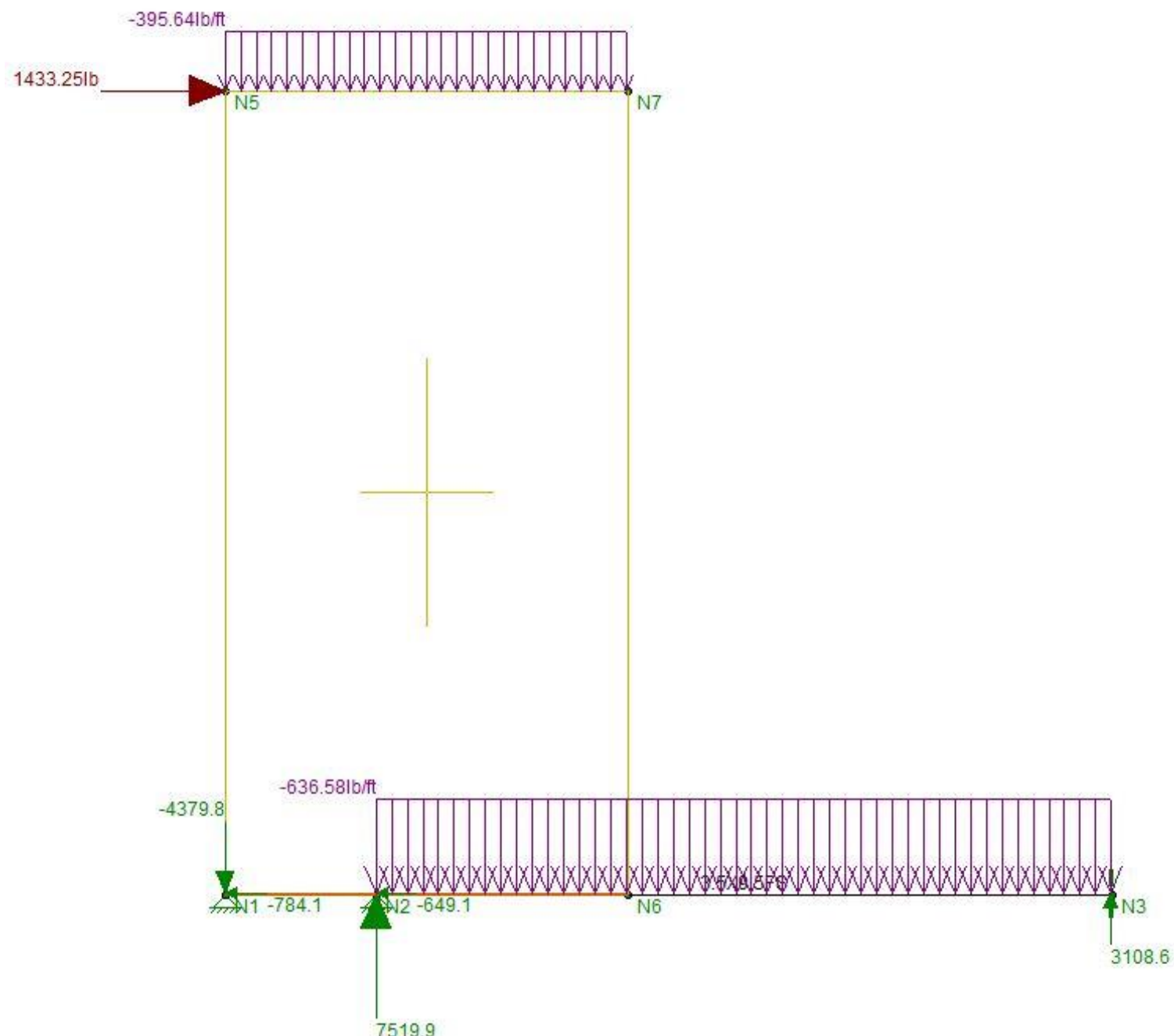

Figure C4. RISA Model Diagram - ASD Basic Load Combination 6 


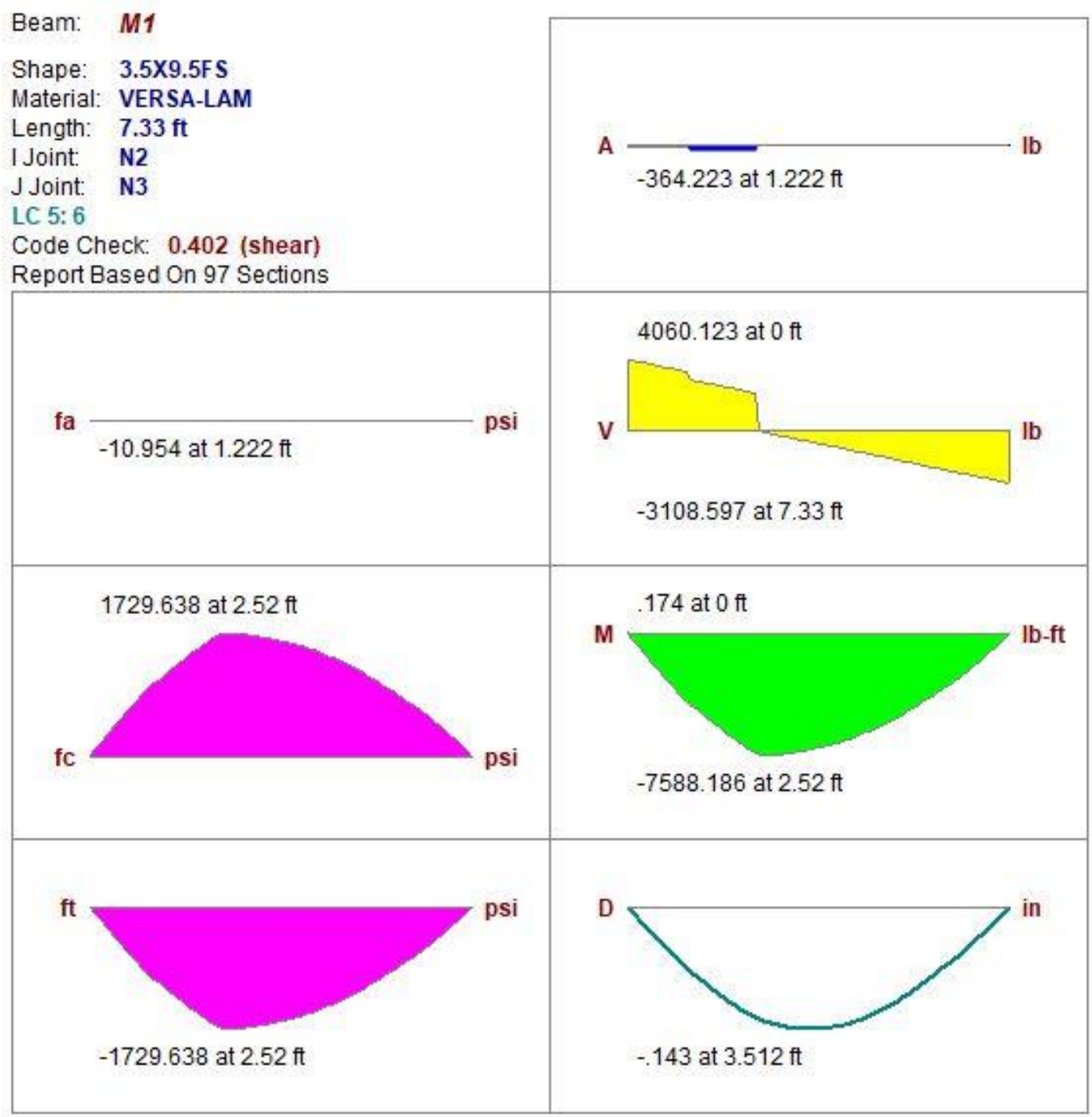

AF\&PA NDS-05/08: ASD Code Check

$\begin{array}{llll}\text { Max Bending Check } & 0.355 & \text { Max Shear Check } & 0.402 \\ \text { Location } & 2.52 \mathrm{ft} & \text { Location } & 0 \mathrm{ft} \\ \text { Equation } & 3.9-3 & \text { Max Defl Ratio } & \text { L/617 }\end{array}$

$\begin{array}{llll}\mathrm{CD} \mathbf{1 . 6} & \mathrm{RB} \mathbf{8 . 2 5 9} & \mathrm{CL} .983 & \mathrm{CV} \mathbf{1} \\ \mathrm{Cr} \mathbf{1} & \mathrm{Cfu} \mathbf{1} & \mathrm{CP} .276\end{array}$

\begin{tabular}{|c|c|c|c|c|c|c|c|}
\hline & (psi) & $\mathrm{Cm}$ & $\mathrm{Ct}$ & CF & \multirow{3}{*}{$\begin{array}{l}\mathrm{Lb} \\
\mathrm{le} / \mathrm{d}\end{array}$} & \multirow{2}{*}{$\begin{array}{l}\text { Out } \\
7.33 \mathrm{ft}\end{array}$} & \multirow{2}{*}{$\begin{array}{l}\text { In } \\
7.33 \mathrm{f}\end{array}$} \\
\hline $\mathrm{Fc}^{\prime}$ & 1325.08 & 1 & 1 & 1 & & & \\
\hline $\mathrm{Ft}^{\mathrm{t}}$ & 3440 & 1 & 1 & 1 & & 25.131 & 9.259 \\
\hline $\mathrm{Fb}^{\prime}$ & 4873.447 & 1 & 1 & 1 & Sway & No & No \\
\hline $\mathrm{Fv}$ & 456 & 1 & 1 & & & g Top & \\
\hline$E^{\prime}$ & $2 \mathrm{e}+6$ & 1 & 1 & & $\mathrm{Le}-\mathrm{Be}$ & g Bot & \\
\hline
\end{tabular}

Figure C5. RISA Software Analysis Results for Beam Below Discontinuity: ASD Basic Load Combination 6 


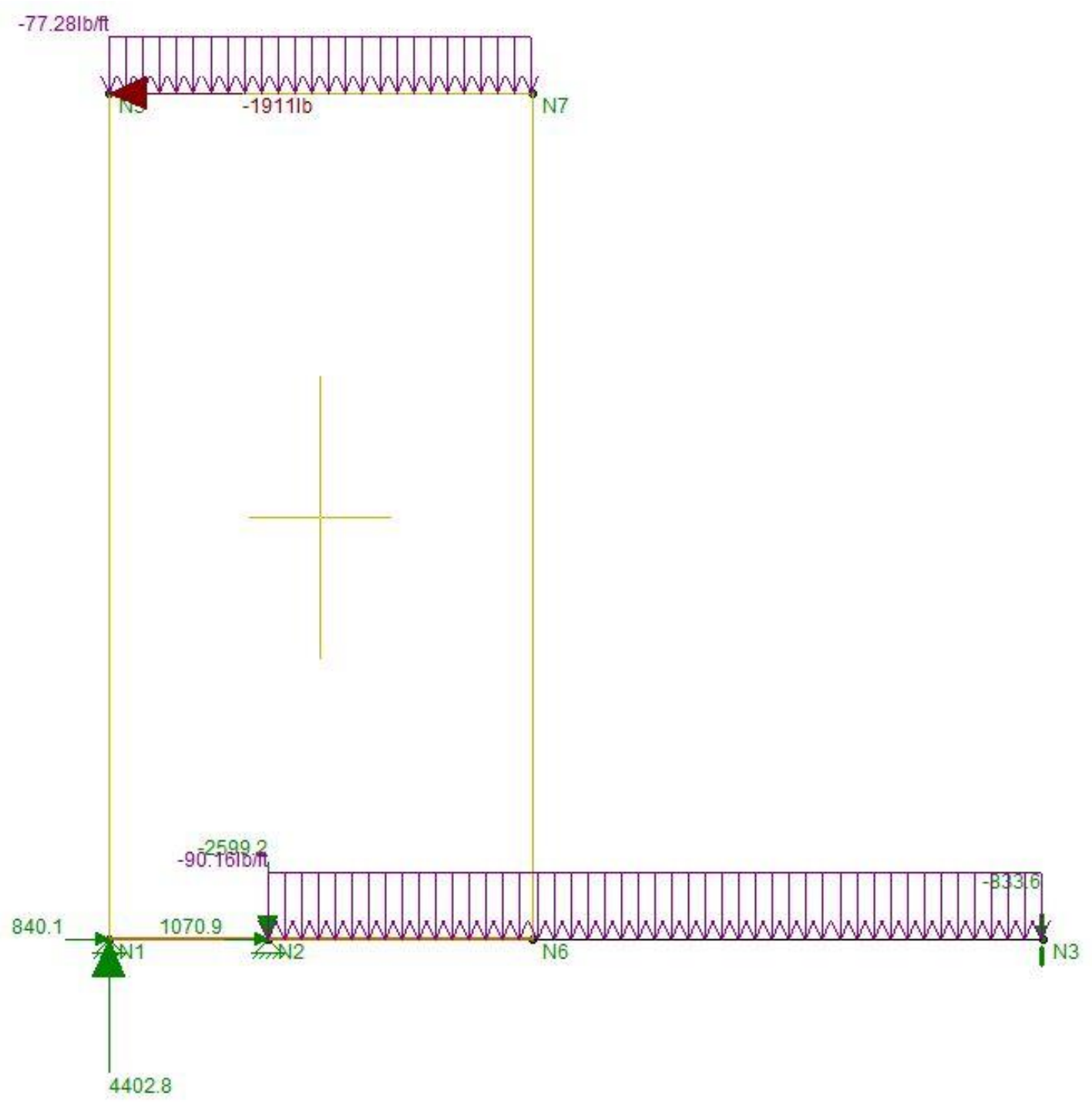

Figure C6. RISA Model Diagram - ASD Basic Load Combination 8 


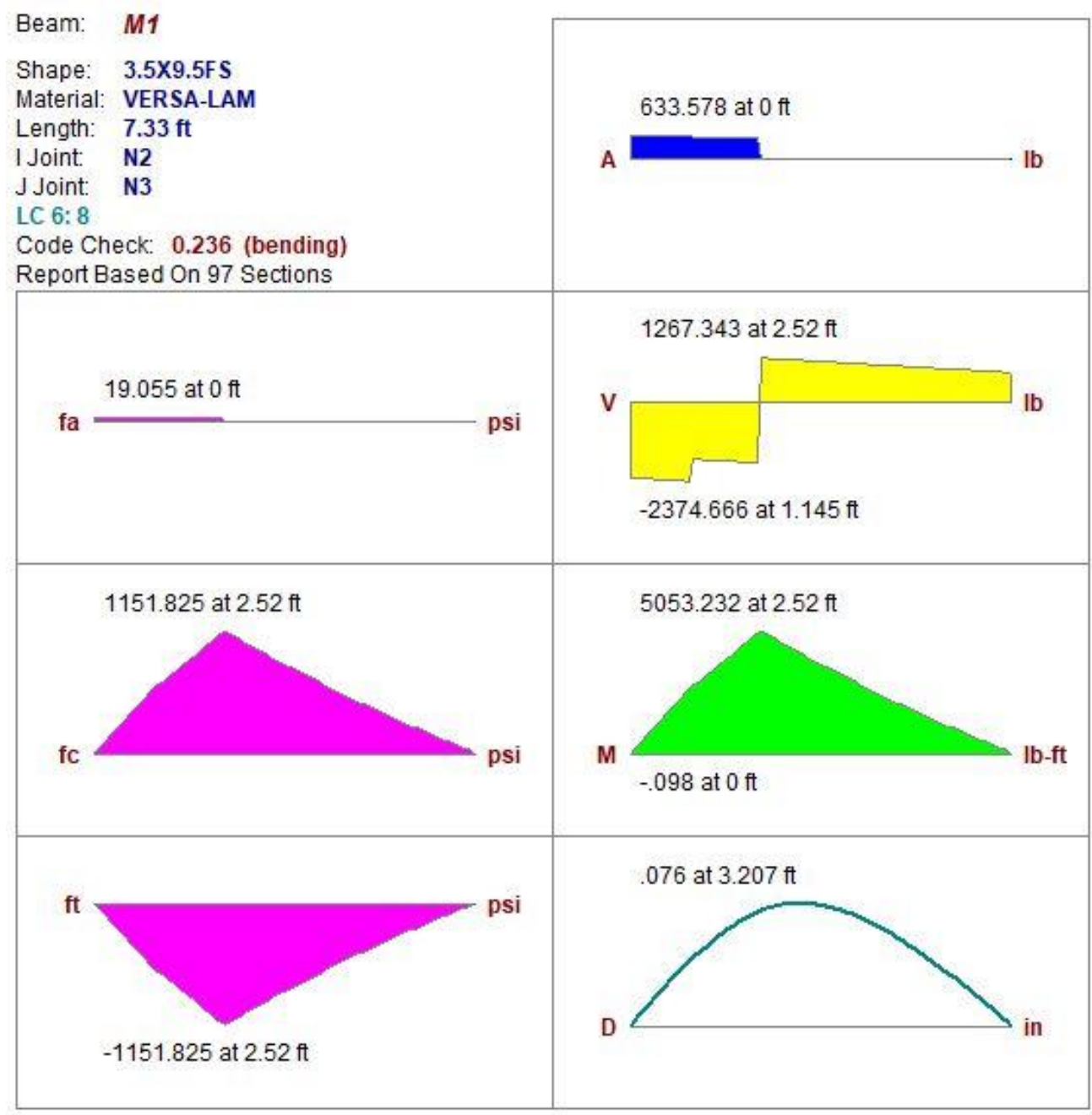

AF\&PA NDS-05/08: ASD Code Check

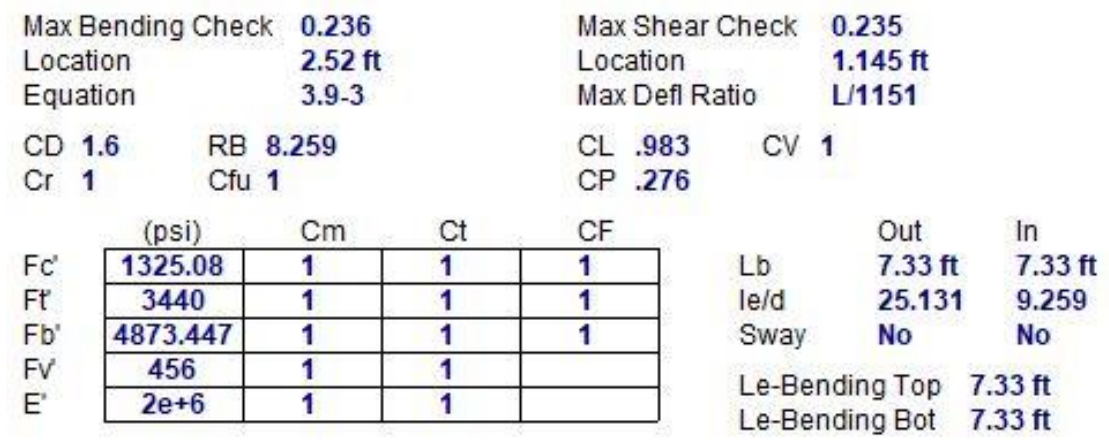

Figure C7. RISA Software Analysis Results for Beam Below Discontinuity: ASD Basic Load Combination 8 


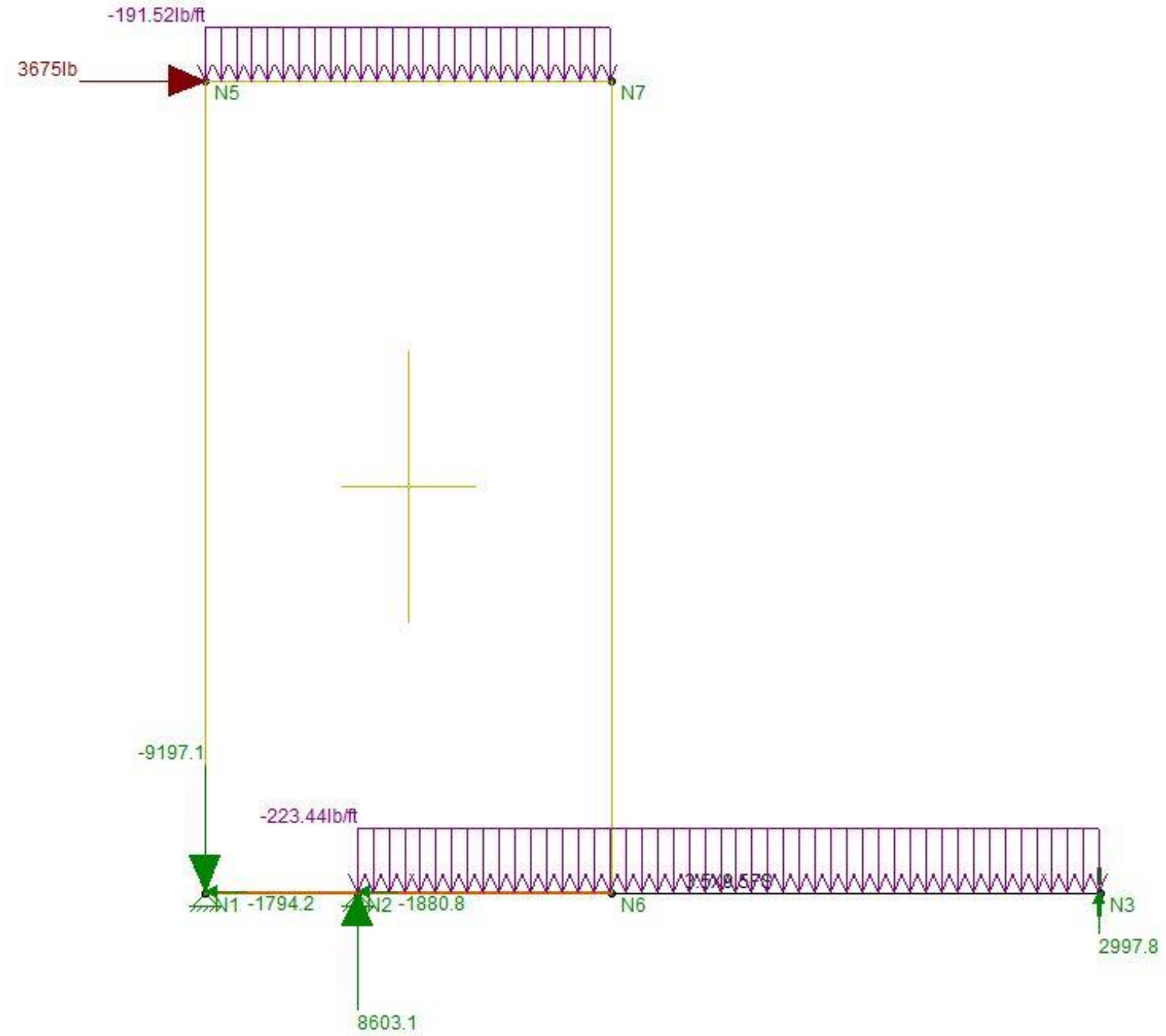

Figure C8. RISA Model Diagram - ASD Load Combination 5 with Overstrength 


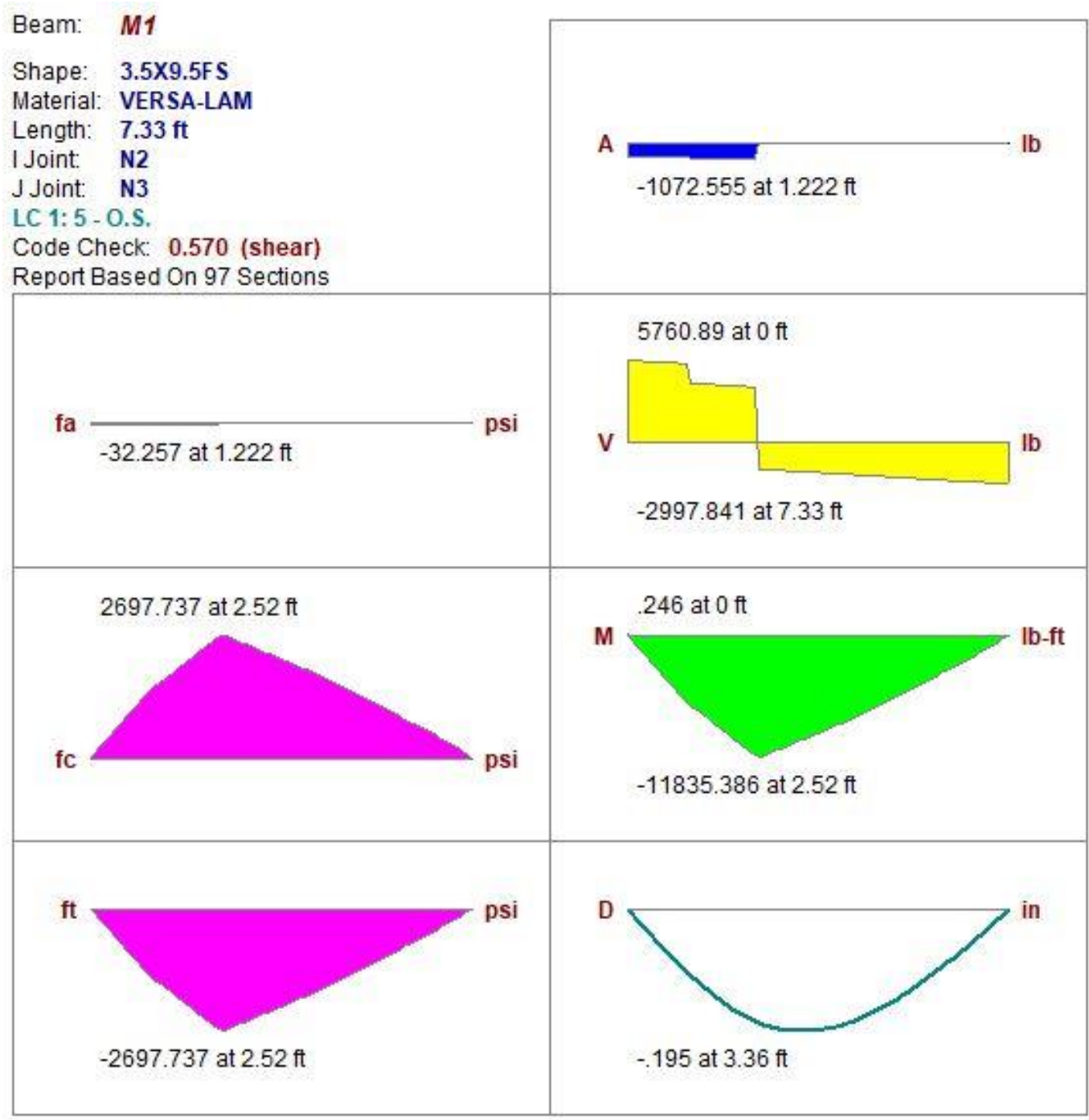

AF\&PA NDS-05/08: ASD Code Check

\begin{tabular}{|c|c|c|c|c|c|c|c|}
\hline \multicolumn{2}{|c|}{$\begin{array}{l}\text { Max Bending Check } \\
\text { Location } \\
\text { Equation }\end{array}$} & \multicolumn{2}{|c|}{$\begin{array}{l}0.554 \\
2.52 \mathrm{ft} \\
3.9-3\end{array}$} & \multicolumn{2}{|c|}{$\begin{array}{l}\text { Max Shear Check } \\
\text { Location } \\
\text { Max Defl Ratio }\end{array}$} & \multicolumn{2}{|l|}{$\begin{array}{l}0.570 \\
0 \mathrm{ft}\end{array}$} \\
\hline $\begin{array}{ll}\mathrm{CD} & \mathbf{1 . 6} \\
\mathrm{Cr} & \mathbf{1}\end{array}$ & & .259 & & $\begin{array}{ll}\text { CL } & .983 \\
\text { CP } & .276\end{array}$ & $\mathrm{CV}$ & 1 & \\
\hline & (psi) & $\mathrm{Cm}$ & $\mathrm{Ct}$ & $\mathrm{CF}$ & & Out & In \\
\hline $\mathrm{Fc}^{\prime}$ & 1325.08 & 1 & 1 & 1 & Lb & $7.33 \mathrm{ft}$ & $7.33 \mathrm{ft}$ \\
\hline $\mathrm{Ft}^{\prime}$ & 3440 & 1 & 1 & 1 & le/d & 25.131 & 9.259 \\
\hline $\mathrm{Fb}^{\prime}$ & 4873.447 & 1 & 1 & 1 & Sway & No & No \\
\hline Fv' & 456 & 1 & 1 & & & & $.33 \mathrm{ft}$ \\
\hline$E^{\prime}$ & $2 e+6$ & 1 & 1 & & Le-Be & nding Bot & $.33 \mathrm{ft}$ \\
\hline
\end{tabular}

Figure C9. RISA Software Analysis for Beam Below Discontinuity: ASD Load Combination 5 with Overstrength 


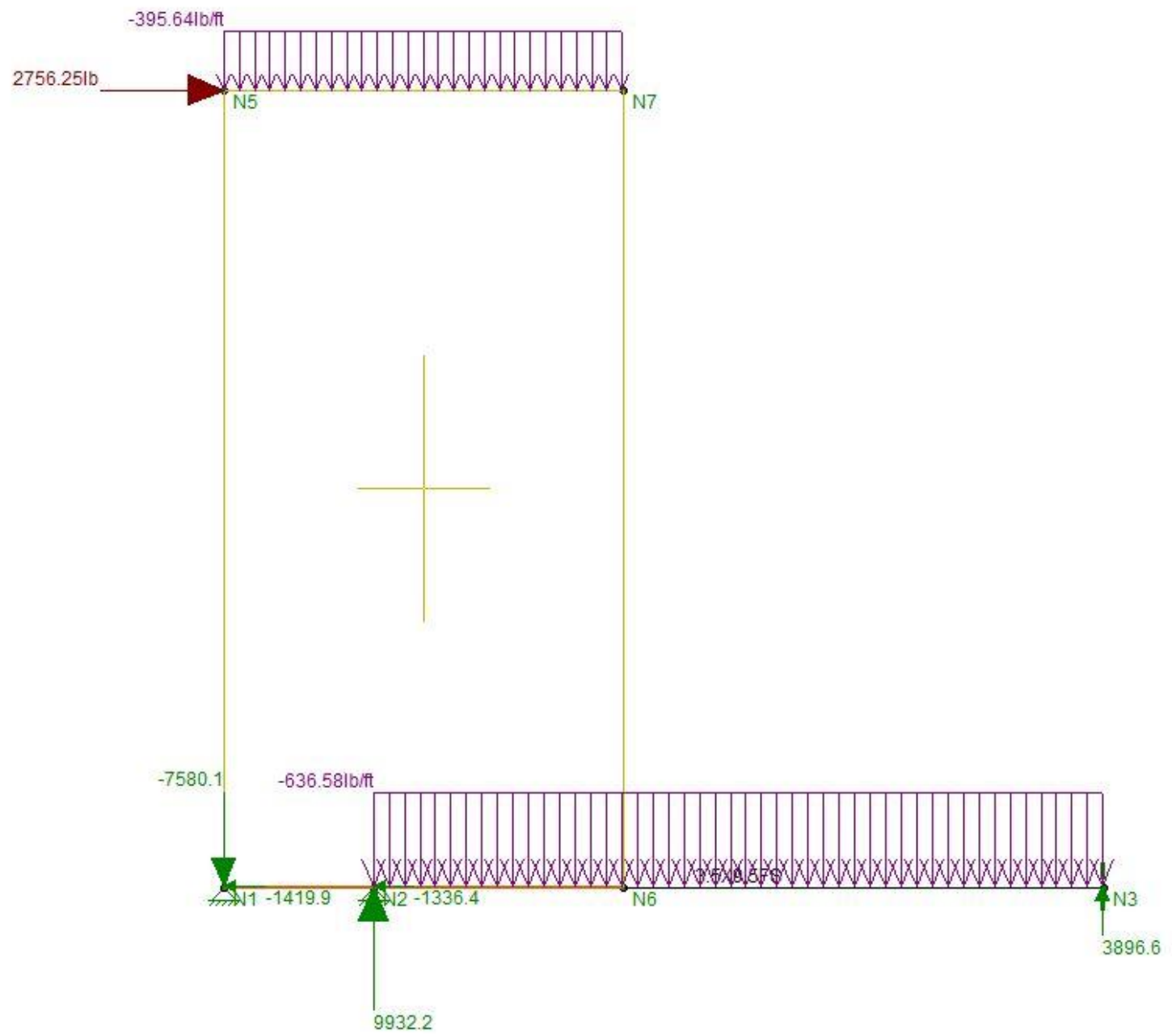

Figure C10. RISA Model Diagram - ASD Load Combination 6 with Overstrength 


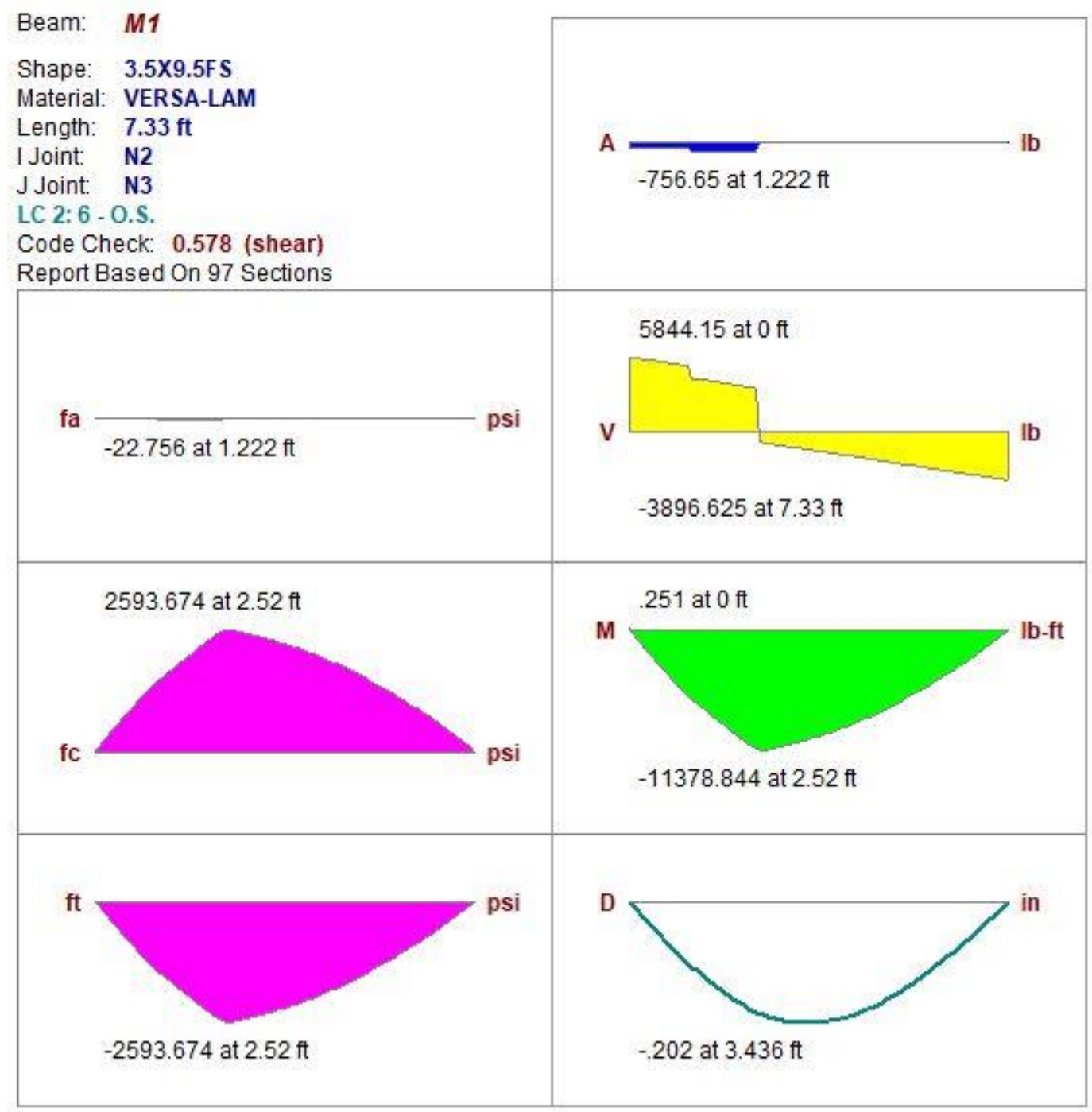

AF\&PA NDS-05/08: ASD Code Check

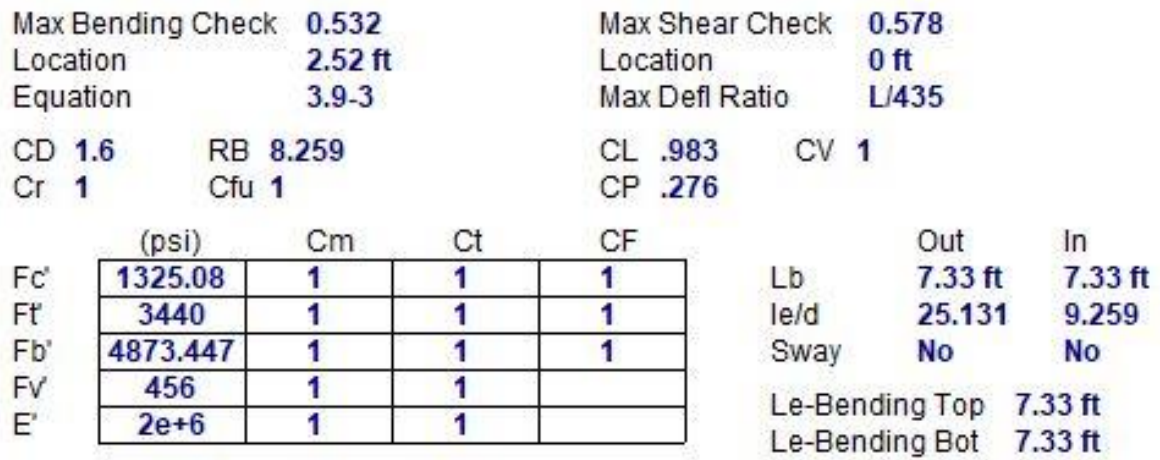

Figure C11. RISA Software Analysis for Beam Below Discontinuity: ASD Load Combination 6 with Overstrength 


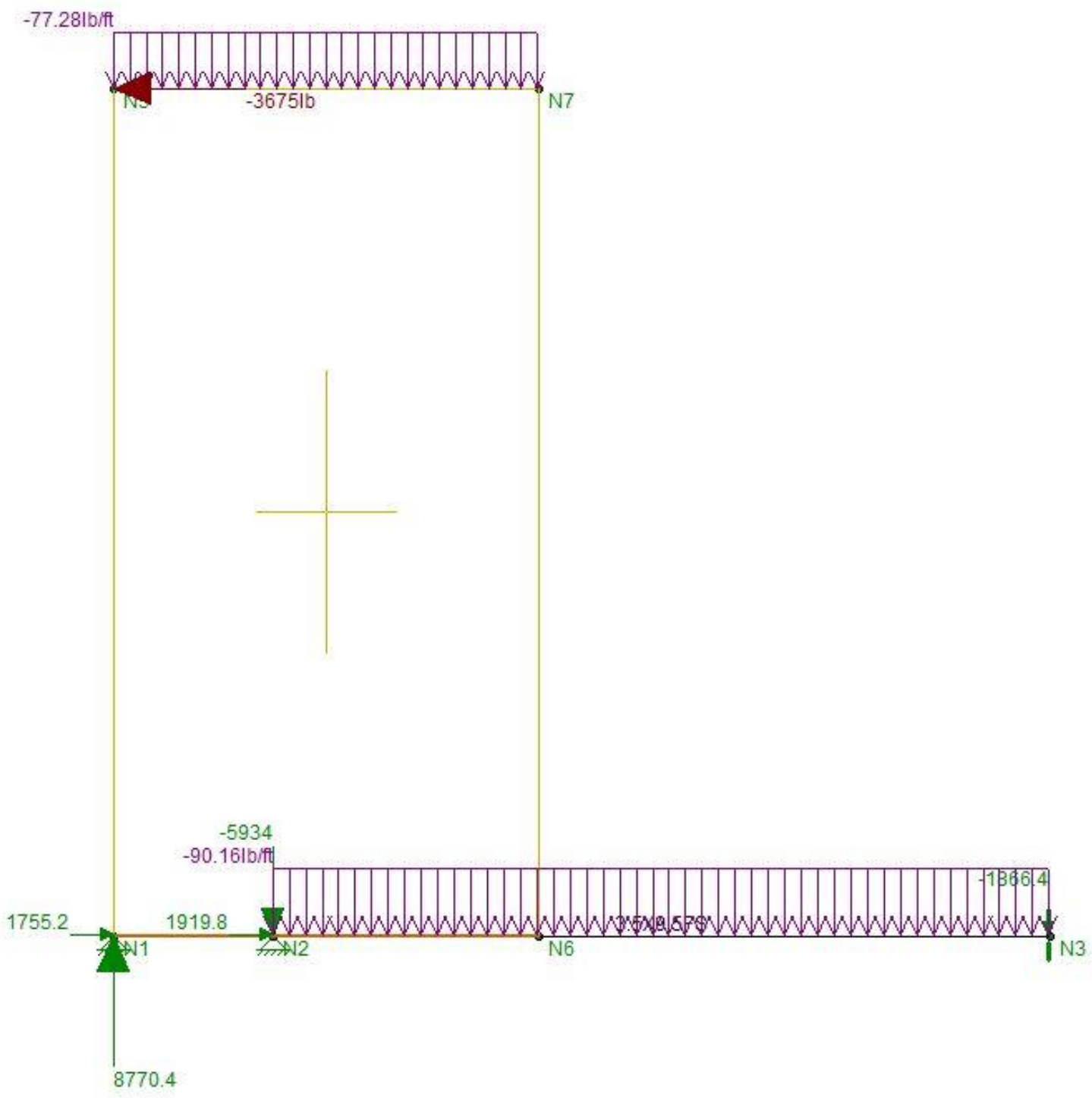

Figure C12. RISA Model Diagram - ASD Load Combination 8 with Overstrength 


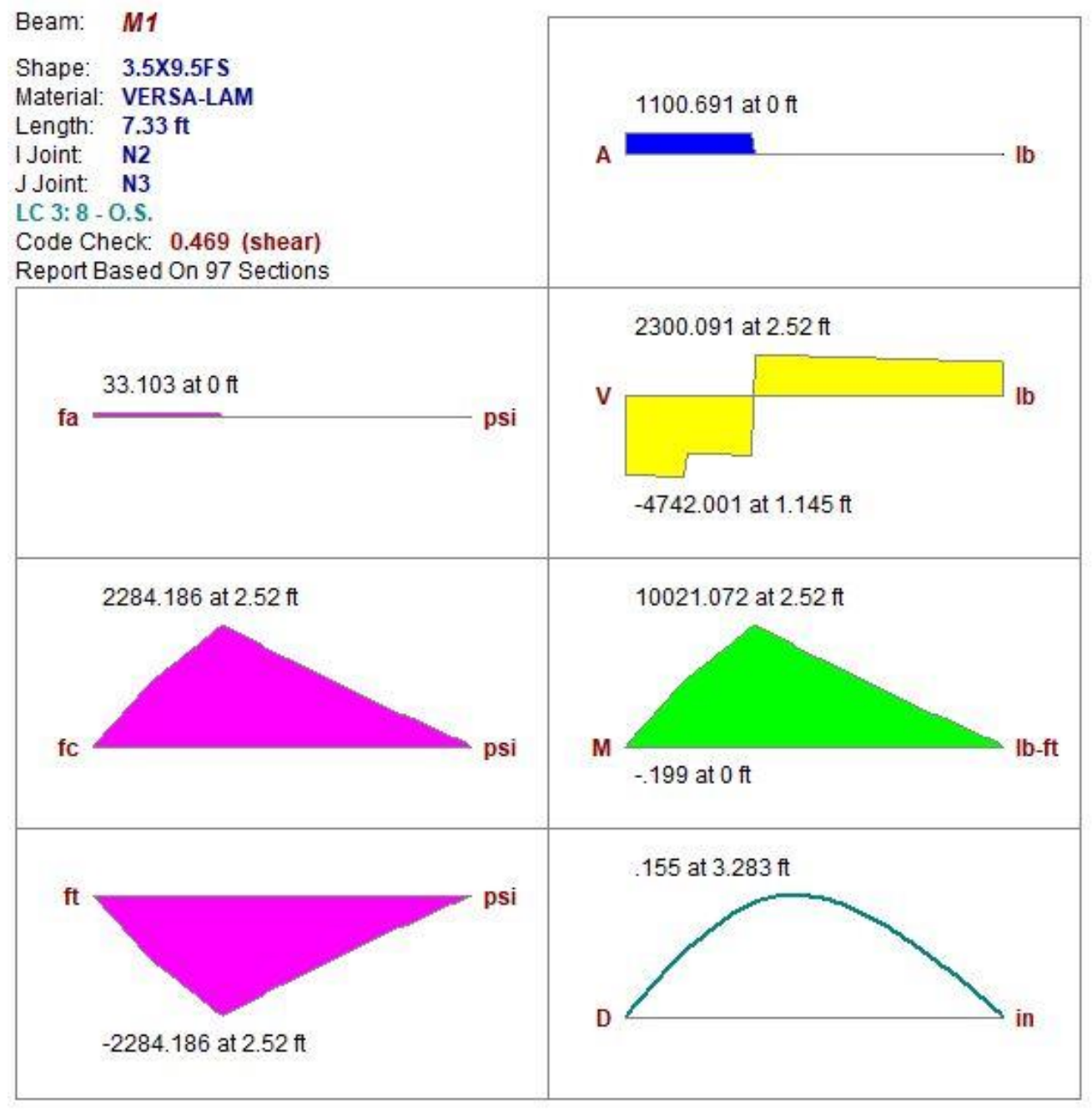

AF\&PA NDS-05/08: ASD Code Check

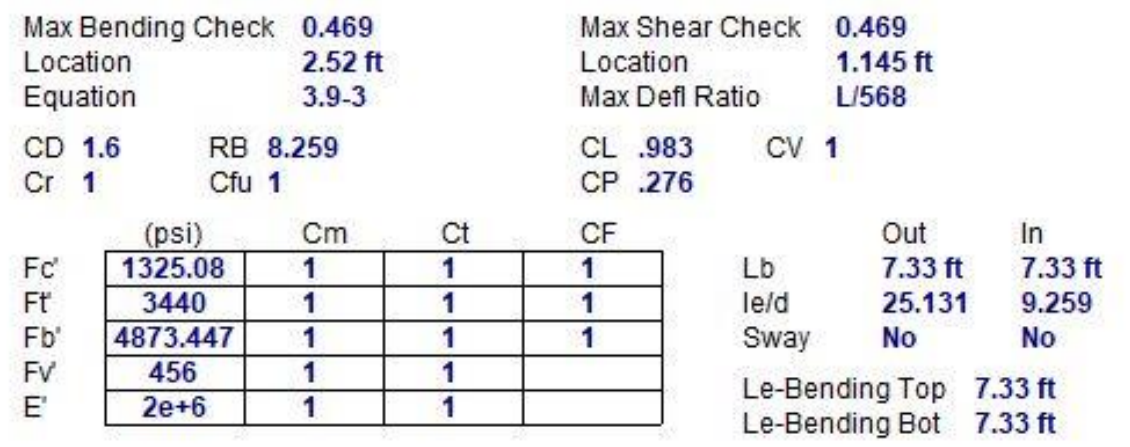

Figure C13. RISA Software Analysis for Beam Below Discontinuity: ASD Load Combination 8 with Overstrength 


\begin{tabular}{llll} 
Company & $:$ San Jose State Civil Engineering & & Mar 20, 2018 \\
Designer & $:$ Rhett Carlsen & & $11: 38$ PM \\
Job Number & $:$ CE 299 & WP1 (In-Plane) & Cheoked By:- \\
Model Name & $:$ Prototype Structure Line B Wall & Pred & \\
\hline \hline
\end{tabular}

\begin{tabular}{|c|c|c|c|c|c|c|c|}
\hline \multicolumn{2}{|l|}{ GENERAL } & \multicolumn{3}{|l|}{ GEOMETRY } & \multicolumn{3}{|c|}{ MATERIALS } \\
\hline Code & AF\&PA NDS-05/08:ASD & Total Height & $: 8$ & $\mathrm{ft}$ & Description & Material & Size \\
\hline Design Method & Segmented & Total Length & 4 & $\mathrm{ft}$ & Top PI & DF/SPine & $2-2 \times 4$ \\
\hline Wall Material & DF/SPine & Max H/W Ratio & $: 2.00$ & & Sill & DF/SPine & $2 \times 4$ \\
\hline Panel Schedule & User Selected & $\mathrm{K}$ & 1.00 & & Wall Stud & DF/SPine & $2 \times 4$ \\
\hline Sel. Shear Pane & : 11 15/32_8d@3 & & & & Chord & DF/SPine & $2-2 \times 4$ \\
\hline
\end{tabular}

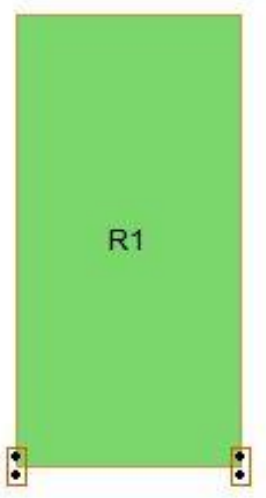

\section{DESIGN DETAILS}

ENVELOPED RESULTS

\begin{tabular}{|l|l|l|l||l|l||l|l||l|l|}
\hline $\begin{array}{l}\text { Controlling } \\
\text { Shear Region }\end{array}$ & Shear Panel & $\begin{array}{l}\text { Shear } \\
\text { UC }\end{array}$ & $\begin{array}{l}\text { Shear } \\
\text { LC }\end{array}$ & $\begin{array}{l}\text { Strap } \\
\text { Force (lb) }\end{array}$ & $\begin{array}{l}\text { Strap } \\
\text { LC }\end{array}$ & $\begin{array}{l}\text { Chord } \\
\text { UC }\end{array}$ & $\begin{array}{l}\text { Chord } \\
\text { LC }\end{array}$ & $\begin{array}{l}\text { Stud } \\
\text { UC }\end{array}$ & $\begin{array}{l}\text { Stud } \\
\text { LC }\end{array}$ \\
\hline R1 & S1_15/32_8... & $\mathbf{0 . 8 6 9}$ & $\mathbf{4}(\mathbf{S})$ & $\mathbf{3 6 9 3 . 5 0 5}$ & $\mathbf{4 ( S )}$ & $\mathbf{0 . 5 8 1}$ & $\mathbf{4 ( \mathbf { S } )}$ & N/C & N/C \\
\hline
\end{tabular}

REGION INFORMATION

\begin{tabular}{|l|l|l|l|l|l|l|l|l|l|}
\hline $\begin{array}{l}\text { Full-Height } \\
\text { Region Label }\end{array}$ & Rat & $\begin{array}{l}\text { Shear } \\
\text { UC }\end{array}$ & $\begin{array}{l}\text { Shear } \\
\text { LC }\end{array}$ & $\begin{array}{l}\text { Strap } \\
\text { Force (lb) }\end{array}$ & $\begin{array}{l}\text { Strap } \\
\text { LC }\end{array}$ & $\begin{array}{l}\text { Chord } \\
\text { UC }\end{array}$ & $\begin{array}{l}\text { Chord } \\
\text { LC }\end{array}$ & $\begin{array}{l}\text { Stud } \\
\text { UC }\end{array}$ & $\begin{array}{l}\text { Stud } \\
\text { LC }\end{array}$ \\
\hline R1 & $\mathbf{2 . 0 0}$ & $\mathbf{0 . 8 6 9}$ & $\mathbf{4}(\mathbf{S})$ & 3693.505 & $\mathbf{4}(\mathbf{S})$ & $\mathbf{0 . 5 8 1}$ & $\mathbf{4 ( S )}$ & $\mathbf{N} / \mathrm{C}$ & N/C \\
\hline
\end{tabular}

DEFLECTION RESULTS

\begin{tabular}{|l|l|l|l|}
\hline $\begin{array}{l}\text { Maximum Region } \\
\text { Deflection (in) }\end{array}$ & Deflection LC & $\begin{array}{l}\text { Finite Element } \\
\text { Deflection (in) }\end{array}$ & $\begin{array}{l}\text { Shear Stiffness } \\
\text { Adjustment Factor (SSAF) }\end{array}$ \\
\hline $\mathbf{1 8 7}$ (R1) & $\mathbf{4}$ & .51 & $\mathbf{1}$ \\
\hline
\end{tabular}

Figure C14. RISA Software Analysis Results for Shearwall Above Discontinuity: ASD Basic Load Combination 5 


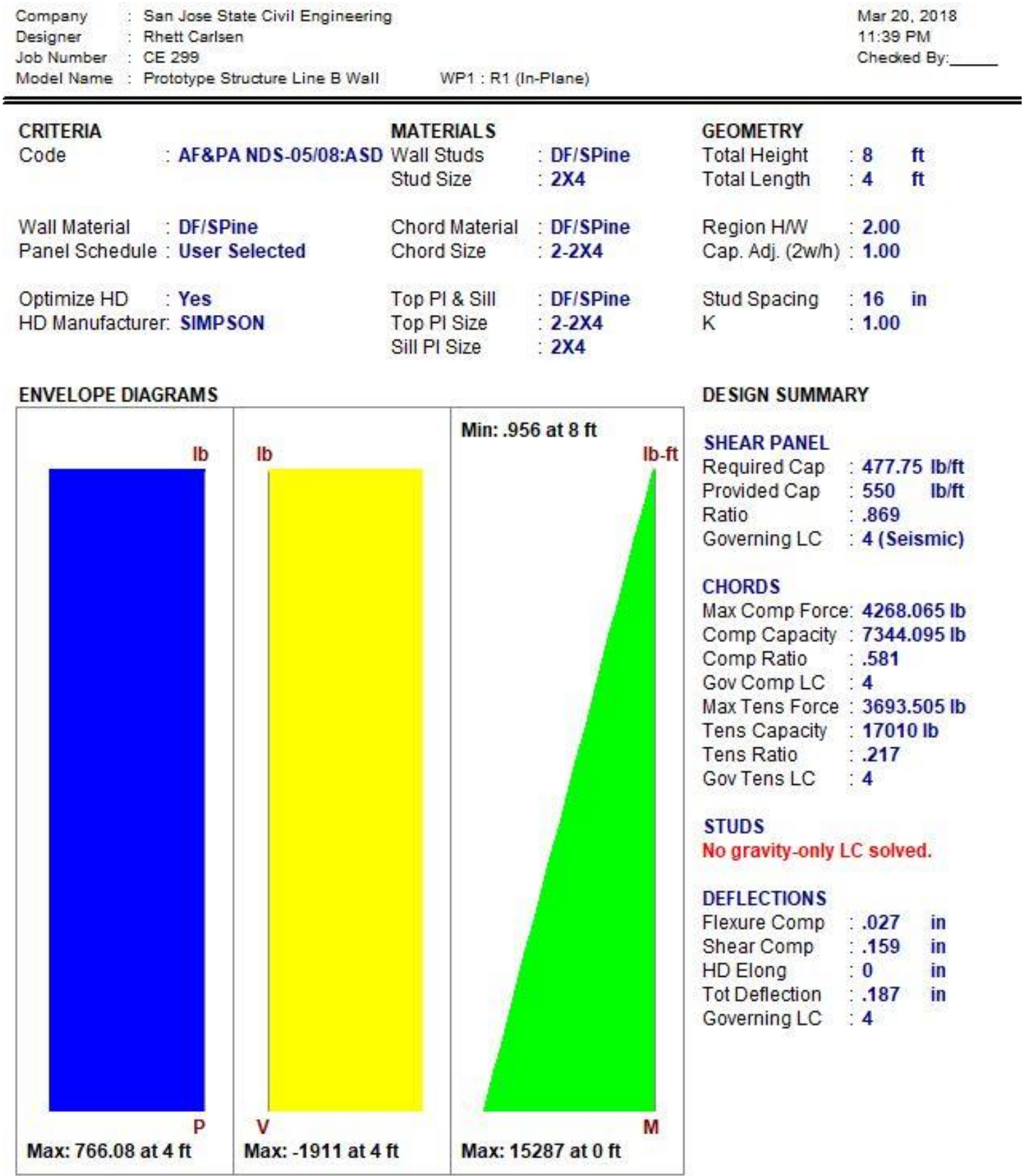

Figure C15. RISA Software Analysis Results for Shearwall Above Discontinuity: ASD Basic Load Combination 5 Continued 
DESIGN DETAILS

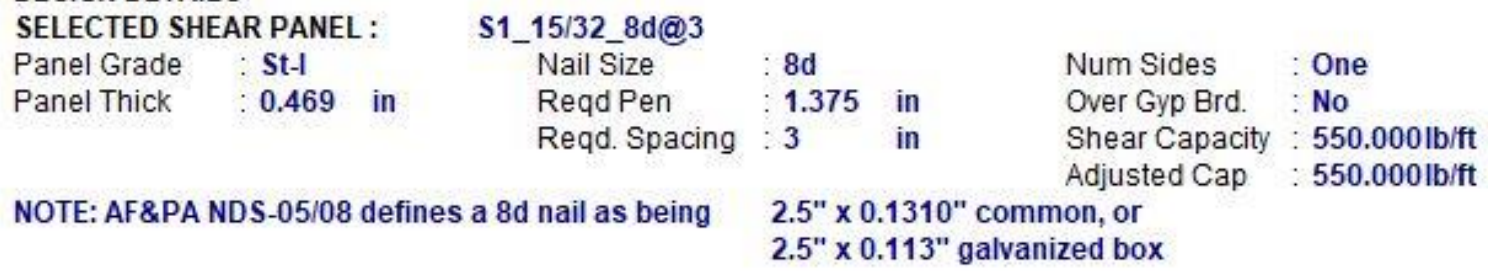

CROSS SECTION DETAILING

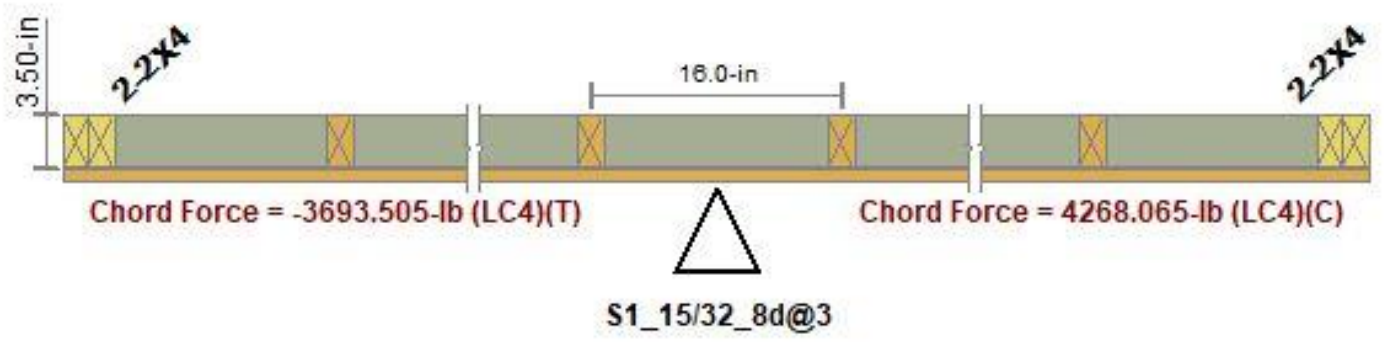

Figure C16. RISA Software Detailing for Shearwall Above Discontinuity 